ADVANCED COAL-FUELED GAS TURBINE SYSTEMS REFERENCE SYSTEM DEFINITION UPDATE

Toplcal Report

September 1991

Work Performed Under Contract No. AC21-86MC23167

For

U.S. Department of Energy Morgantown Energy Technology Center Morgantown, West Virginia

By Westinghouse Electric Corporation Orlando, Florida 


\section{DISCLAIMER}

This report was prepared as an account of work sponsored by an agency of the United States Government. Neither the United States Government nor any agency thereof, nor any of their employees, makes any warranty, express or implied, or assumes any legal liability or responsibility for the accuracy, completeness, or usefulness of any information, apparatus, product, or process disclosed, or represents that its use would not infringe privately owned rights. Reference herein to any specific commercial product, process, or service by trade name, trademark, manufacturer, or otherwise does not necessarily constitute or imply its endorsement, recommendation, or favoring by the United States Government or any agency thereof. The views and opinions of authors expressed herein do not necessarily state or reflect those of the United States Government or any agency thereof.

This report has been reproduced directly from the best available copy.

Available to DOE and DOE contractors from the Office of Scientific and Technical Information, P.O. Box 62, Oak Ridge, TN 37831; prices available from (615)576-8401, FTS 626-8401.

Available to the public from the National Technical Information Service, U.S. Department of Commerce, 5285 Port Royal Rd., Springfield, VA 22161. 


\title{
Advanced Coal-Fueled Gas Turbine Systems \\ Reference System Definition Update
}

\author{
Topical Report
}

Work Performed Under Contract No.: DE-AC21-86MC23167

For

U.S. Department of Energy

Office of Fossil Energy

Morgantown Energy Technology Center

P.0. Box 880

Morgantown, West Virginia 26507-0880

\author{
By \\ Westinghouse Electric Corporation \\ Power Generation Business Unit \\ 4400 Alafaya Trail \\ Orlando, Florida 32826-2399
}

September 1991 
Section

Page

BACKGROUND..................................... vi

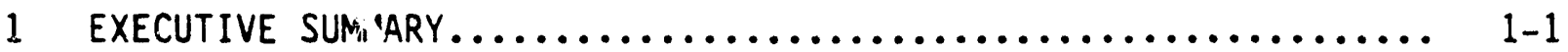

2 PLANT PERFORMANCE................................. 2-1

2.1 Assumptions....................................... $2-1$

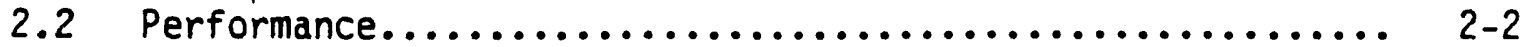

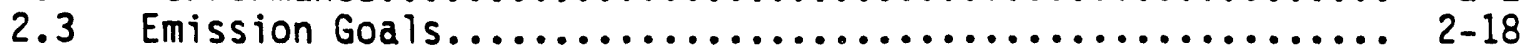

3 ECONOMICS.......................................... $3-1$

3.1 Economic Assumptions.............................. 3-1

3.1.1 Criterion: Cost of Electricity............... 3-1

3.1.2 Power Plant Definition...................... 3-1

3.1.3 Plant Financial Data.......................... 3-3

3.1.4 COE of Conventional Plants.................... 3-4

3.2 Cost of Electricity Calculations.................. 3-15

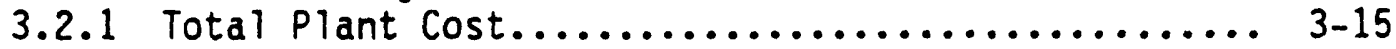

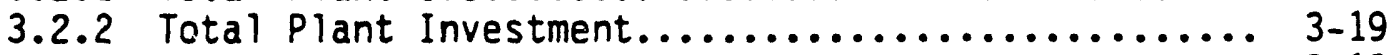

3.2.3 Total Capital Requirements................... 3-19

3.3 Operation and Maintenance Cost...................... 3-21

3.3.1 Operating Costs............................. 3-21

3.3.2 Maintenance Costs.......................... 3-22

3.3.3 Fixed and Variable Components................ 3-22

3.4 Fue 1 and Consumables.............................. 3-23

3.5 Cost of Electricity Estimate..................... 3-24

3.6 COE of a Mature Plant........................... 3-25

4 SLAGGING COMBUSTOR DESCRIPTION....................... 4-1

4.1 Slagging Combustor Concept........................ 4-1

4.2 Particulate Control............................ 4-2

4.3 Sulfur Control................................... 4-2

4.4 Nitrogen Oxide Controi.............................. 4-3

4.5 Alkali Control.................................. $4-3$

5 ECONOMIC SENSITIVITY STUDIES........................ $5-1$

5.1 Combustor Out let Temperature...................... $5-1$

5.2 Slurry Chemical Expense............................ 5-3

5.3 Sulfur Capture................................ 5-3

5.4 Combustor Capital Cost............................ 5-7

5.5 Turbine Reblading Interval...................... 5-7

5.6 Combustor Pressure Loss......................... 5-9

5.7 Combustor Heat Rejection........................ 5-10

5.8 Natural Gas Prices............................. 5-12

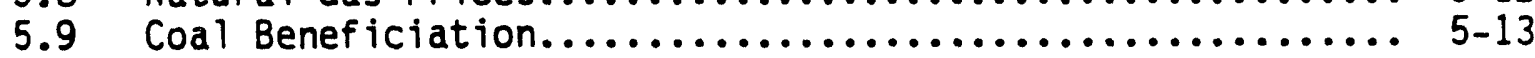




\section{TABLE OF CONTENTS (Continued)}

6 PLANT DESCRIPTION....................................... $6-1$

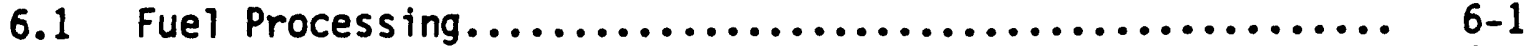

6.2 Combustion Turbine Assembly........................ 6-4

6.3 Steam Turbine Cycle................................ 6-8

6.4 Slag Disposal System............................... 6-9

APPENDIX A LICADO COal Cleaning Process.................... A-1

APPENDIX B Other Coal Cleaning Processes.................. B-1 


\section{LIST OF TABLES}

Tables

Page

1-1

1-2

2-1

2-2

2-3

2-4

2-5

2-6

2-7

3-1

3-2

3-3

3-4

3-5

3-6

3-7

3-8

3-9

3-10

3-11

3-12

3-13

3-14

3-15

3-16

3-17

3-18

3-19

3-20

3-21

3-22

3-23

3-24

3-25

3-26

5-1

5-2

5-3

5-4

5-5

5-6

5-7

5-8

5-9

5-10

5-11

Conventional Plants - Design Conditions

$1-2$

Summary of CFCTCC Power Plant Performance

1-3

Reference System Plant Performance

$2-1$

CWM Coal-Fueled Combined Cycle Thermodynamic Data

$2-9$

Dry Coal-Fueled Combined Cycle Thermodynamic Data

$2-12$

Combined Cycle Power Summary

$2-15$

CWM Combined Cycle Energy Balance

$2-15$

Dry Coal-Fueled Combined Cycle Energy Balance

$2-17$

Emissions Goals

Reference System Plant Characteristics

$2-18$

$3-2$

Fuel Characteristics

Sorbent Constituents

$3-2$

$3-3$

Financial Assumptions

Operating Costs

Conventional Plants - Design Conditions

Conventional Plants - Capital Requirements

$3-3$

$3-4$

$3-4$

$3-5$

Conventional Plants - Operating Costs

Conventional Plants - COE Summary

PC-FGD Plants - COE Summary

PC-FGD Plant Financial Basis

Gas-Fueled Combined Cycle COE Summary

0il-Fueled Combined Cycle COE Summary

Gas-Fueled Combined Cycle Financial Basis

0il-Fueled Combined Cycle Financial Basis

PC CFCTCC Plant Costs

CWM CFCTCC Plant Costs

Development Categories

Process Contingency Factors

First CFCTCC Plant Capital Requirements

CFCTCC Plant Operating Labor Requirements

CFCTCC Maintenance Factors

CFCTCC Fuel and Consumables

CFCTCC Reference System Operating Costs

$3-6$

3-6

$3-8$

$3-9$

$3-11$

$3-12$

$3-13$

$3-14$

$3-17$

$3-17$

$3-18$

$3-18$

$3-20$

3-21

$3-22$

$3-23$

$3-24$

First CFCTCC Plant COE Summary

$3-25$

Mature CFCTCC Plant COE Summary

$3-25$

COE Sensitivities

COE Sensitivity to Firing Temperature

$5-1$

$5-2$

$5-3$

COE Sensitivity to Ca/S Ratio (with 90\% Sulfur Capture)

COE Sensitivity to Ca/S Ratio (with FGD)

COE Sensitivity to Taconite $\mathrm{Fe} / \mathrm{S}$ Ratio

$5-5$

$5-5$

$5-6$

Taconite and Other Consumable Costs

$5-7$

COE with Taconite for CFCTCC - CWM

$5-8$

Turbine Reblading Interval

COE Sensitivity to Reblading Interval

COE Sensitivity to Combustor Pressure Loss

$5-9$

$5-10$

COE Sensitivity to Combustor Cooling (Reject Heat Used)

$5-10$

5-12

COE Sensitivity to Combustor Cooling

(Energy Lost from Cycle)

$5-11$ 


\section{LIST OF TABLES}

Tables

Page

5-13 Comparative Rankings

$5-14$

5-14 Performance Comparisons

$5-14$

5-15 Capital Cost Comparisons

$5-15$

$5-15$

COE Comparisons

$6-1$

Fuel Processing

$6-2$

Characteristics

$5-15$

Coal and CWM Characteristics

6-1

Combustion Turbine Performance Data

$6-1$

$6-3$

Combustion Turbine Stream Data

$6-4$

$6-4$

Turbine Performance with Natural Gas

$6-5$

6-5

Steam Turbine Performance Data

6-6

$6-6$

Key Cost and Design Parameters

6-9

B-3

B-2

Process Consumables

B-5 


\section{LIST OF FIGURES}

Figure

Page

1-1 Comparison of COE for Conventional Power Plants

$2-1$ and PC and CWM CFCTCC Reference Plants

$1-3$

Power System Arrangement

Block Flow Diagram - Direct Coal-Fueled Combined Cycle

$2-3$

$2-2$ Slagging Combustor Process Flow Diagram Combustion Turbine Cycle

Heat Recovery Steam Generator

COE Margin vs. Firing Temperature

$3-16$

COE Margin vs. Ca/S Ratio

COE Margin for Plant with FGD

COE Margin vs. Combustor/Cyclone Pressure Drop 


\section{BACKGROUHD}

The objective of the Direct Coal-Fueled $80 \mathrm{MW}$ Combustion Turbine Program is to establish the technology required for private sector use of an advanced coalfueled combustion turbine power system. The system is to burn low-cost, utility-grade coal, and yet meet the EPA New Source Performance Standards for coal-fired steam generators. Plant thermal efficiency is to surpass competing coal-utilization cycles.

Under this program the technology for a direct coal-fueled 80 MW combustion turbine is to be developed. This unit would be an element in a $207 \mathrm{MW}$ direct coal-fueled combustion turbine combined cycle which includes two combustion turbines, two heat recovery steam generators and a steam turbine.

Key to meeting the program objectives is the development of a successful high pressure slagging combustor that burns coal, while removing sulfur, particulates, and corrosive alkali matter from the combustion products. Westinghouse and Textron (formerly AVCO Research Laboratory/Textron) have designed and fabricated a subscale slagging combustor. This slagging combustor, under test since September 1988, ha, been yielding important experimental data, while having undergone several design iterations.

Therefore, it is the objective of this report to provide the current effort to evaluate the relative economic benefits of various design and process options for the direct coal-fueled combustion turbine combined cycle.

In particular the report discusses the following:

1) The assumptions, performance and emission goals of the two reference coal-fueled combustion turbine systems which burn either pulverized coal (PC) or coal-water mixture (CWM).

2) Plant economics; the assumptions made, cost of electricity calculations $(\mathrm{COE})$, estimates for operation and maintenance, consumables and $\mathrm{COE}$, and the COE of a mature plant.

3) Description of the slagging combustor which includes the concept and how particulates, sulfur, nitrogen oxide and alkali are controlled.

4) Economic sensitivity studies; an assessment of the influence of different parameters on the COE margin of the CWM-fueled plant.

5) Description of the coal-fueled gas turbine combined cycle power plant. 


\section{EXECUTIVE SUMARY}

Previous conceptual design studies indicated that a combustion turbine combined cycle fueled by utility-grade pulverized coal could operate with a cost of electricity (COE) lower than the COE of a conventional pulverized coal power plant. The key component of this direct-fired system is a slagging combustor that burns coal while removing sulfur, particulates, and corrosive alkalit matter from the combustion products.

Subscale development testing of a unique slagging combustor design has been yielding important experimental data since September 1988, and it is now appropriate to update and expand the previous conceptual design studies.

This report contains the current effort to evaluate the relative economic benefits of various design and process options for the direct coal-fueled combustion turbine combined cycle. A power system computer model is used to compare the proposed design alternatives with a conventional coal-fired steam turbine power plant and conventional combustion turbine combined cycles in terms of performance, capital cost, and cost of electricity. All performance data is based on the higher heating value (HHV) of the fuel and all costs are in 1989 dollars.

The technical assumptions on which the current standard Westinghouse coalfueled combustion turbine combined cycle (CFCTCC) is based includes: using Pittsburgh No. 8 coal (standard utility grade); ambient conditions of 14.7 psia, $59^{\circ} \mathrm{F}$, and a relative humidity of $60 \%$; NSPS emissions criteria; use of a slagging combustor whose rich/lean zone reduces $\mathrm{NO}_{\mathrm{x}}$ formation; use of limestone as a sorbent to capture sulfur $(\mathrm{Ca} / \mathrm{S}=2)$; use of slagging cyclone seperators to reduce particulate matter and solid alkali; combustor outlet temperature of $1850^{\circ} \mathrm{F}$; maximum turbine metal temperature of $1650^{\circ} \mathrm{F}$; pressure drop of $7 \%$ through the slagging combustor system; and, partial recovery of an $8 \%$ combustor heat loss.

The economics and performance of the CFCTCC reference plant were compared to three conventional plants: a $220 \mathrm{MW}$ conventional pulverized coal-fired steam turbine generator plant with flue gas desulfurizer (FGD) (This plant, PC-FGD, is fueled with Pittsburgh No. 8 coal), and two combustion turbine combined cycles (CTCC) plants, one fueled with distillate oil and the other plant fueled with natural gas. The sizes of the comparison plants were chosen to approximate the generating capacity of the CFCTCC reference systems.

The design values on which the costs were based reflect generic design conditions for the conventional plants. Table 1-1 summarizes the design conditions of each plant. Pittsburgh No. 8 coal was priced at $\$ 1.80 / \mathrm{MMBtu}$ and gas and oil were priced at $\$ 4.00 / M M B t u$ delivered to the power plants studied. These prices are based on the HHV of the fuels.

Capital costs for the PC-FGD plant were developed consistent with the cost basis of the reference CFCTCC. The conceptual cost estimate for the PC-FGD plant is intended to cover a complete plant, including all equipment, materials, labor and construction support. 
Table 1-1. Conventional Plants - Design Conditions

Plant Type

Plant Output, MW

Fuel Type

Fuel HHV, Btu per

Plant Heat Rate, Btu/kWh

Boiler

Steam Turbine Generator [1]

Cooling Tower [2]

Sulfur Control System

Fue 1 Cost, S/MMBtu

Construction Time, yrs

Book Life, yrs

TPC Year

TPI Year

Capacity Factor
PC-FGD

220

Pgh. 8 Coal

$13,555 / 1 b$

9,960

Subcrit

$\mathrm{TC} / 2 \mathrm{~F}$

$M D$, Wet

Limestone FGD

$\$ 1.80$

3.5

30

Dec 1989

Jan 1990

$70 \%$

$$
\begin{array}{r}
\text { CTCC, gas } \\
262 \\
\text { Nat Gas } \\
1,035 / S C F \\
8,208 \\
\text { Subcrit } \\
T C / 2 F \\
M D, \text { Wet } \\
\text { none } \\
\$ 4.00 \\
2.0 \\
30 \\
\text { Dec } 1989 \\
\text { Jan } 1990 \\
70 \%
\end{array}
$$

CTCC, 0 il

258

No. $20 i 1$

$138,690 / \mathrm{ga} 1$

8,227

Subcrit

$\mathrm{TC} / 2 \mathrm{~F}$

$M D$, Wet

none

$\$ 4.00$

2.0

30

Dec 1989

Jan 1990

$70 \%$

[1] Tandem Compound, Double Flow

[2] Mechanical Draft, Wet

The costing bases for the two combined cycle plants are also consistent with the reference CFCTCC plants. Power is produced by two combustion turbines and one steam turbine with a combined output of around $260 \mathrm{MW}$.

The 30-year levelized costs of electricity ( $\$ / M W h$ ) for the three conventional plants and the two CFCTCC reference plants are: 94.4 (PC-FGD), 84.1 (CTCC, gas). 85.2 (CTCC, 0i1), 84.05 (CWM-CFCTCC), and 77.51 (PC-CFCTCC). The COES of the CFCTCC are lower than the PC-FGD, by $11 \%$ and $17.9 \%$ for the CWM and PC plants, respectively and comparable to the gas and oil-fired combined cycles.

In Figure 1-1, the COE for the three conventional and two coal-fueled combined cycles studied is divided into the cost areas of capital and maintenance, consumables and fuel. Capital and maintenance costs dominate the PC-FGD COE, while the COE of the oil-and gas-fired combined cycles is set and controlled by the fuel costs.

As would be expected, the COE of the coal-fueled combined cycles has a large capital and maintenance cost and also a large consumable cost when compared to a gas-or oil-fired combined cycle plant. The CWM plant consumable costs are higher than for a PC combined cycle plant due to the costs associated with making the slurry.

The CFCTCC power plant performance is summarized in Table 1-2. The CWM plant generates 9.5 MWs more power than the PC plant, but has a plant cycle efficiency which is lower by 1.8 percentage points. Evaporation of the water contained in the CWM causes this phenomenon to occur. 


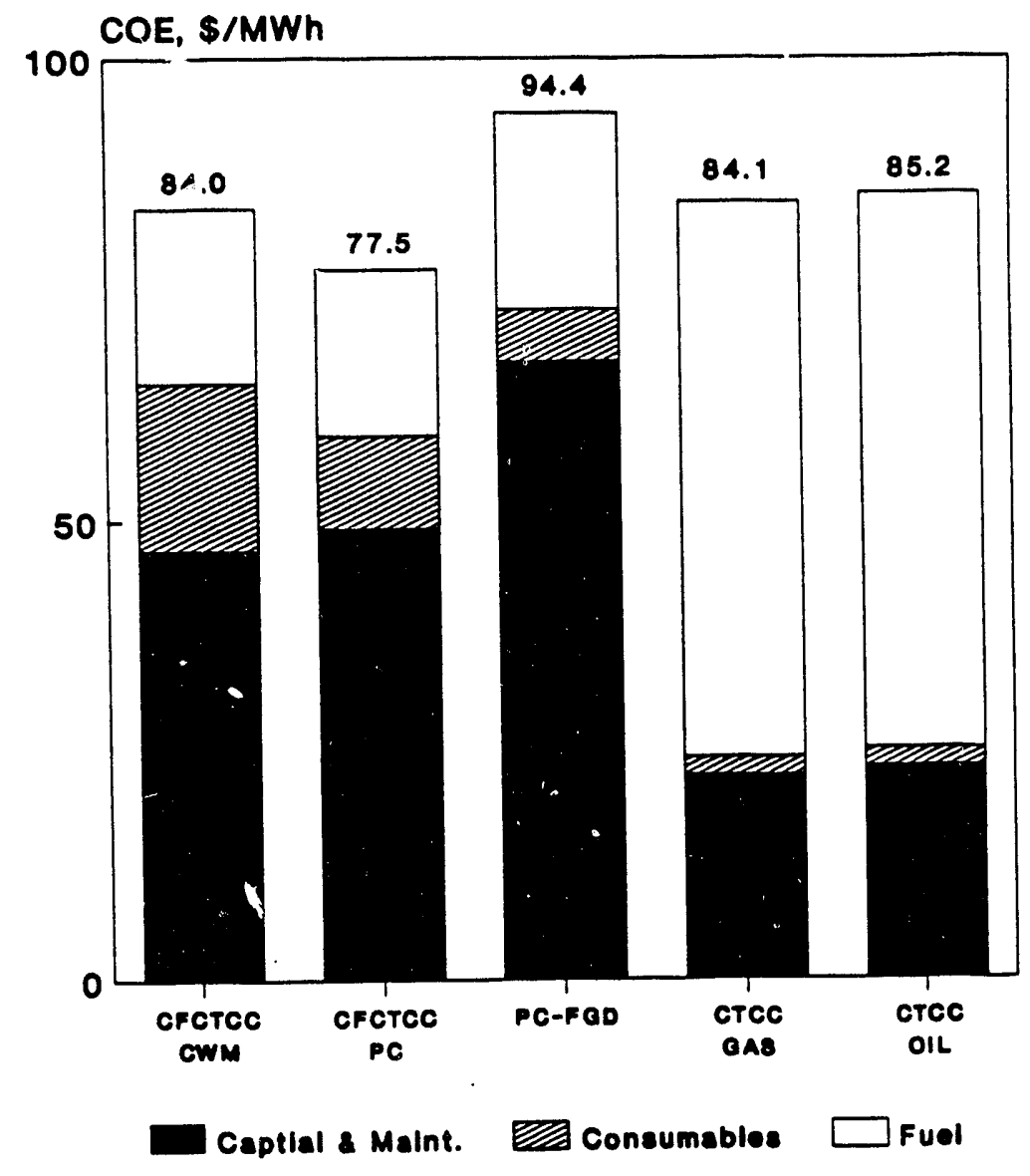

Figure 1-1. Comparison of COE for Conventional Power Plants and PC and CiN CFCTCC Reference Plants

Table 1-2. Summary of CFCTCC Power Plant Performance

\section{Plant Type}

Combustion Turbine Net Power (MW)

Steam Turbine Net Power (MW)

Fuel Processing \& Auxiliary Power (MW)

Net Power Generation (MW)

Net Heat Rate (Btu/kWh)

Efficiency (Percent)
CWM

$$
172.1
$$

63.9

(4.7)

231.3

8924.0

38.2
PC

161.3

62.6

(2.0)

221.8

8536.0

40.0

Sensitivity studies were also performed using the reference system computer model to assess the influence of certain parameters on the COE margin of the CWM and PC CFCTCC plants. Some of the parameters siudied included: combustor outlet temperature, combustion turbine blading interval, $\mathrm{Ca} / \mathrm{S}$ ratio and possible FGD instailation, combustor pressure loss, combustor heat rejection, and slurry chemical expense and coal beneficiation. A detailed review of these arid other parameters are contained in Chapter 5 . 
The coal beneficiation processes studied are discussed in Appendices $A$ and B. Appendix A discusses the LICADO process which was developed by Westinghouse and the University of Pittsburgh, and funded by the Department of Energy and the Pennsylvania Energy Development Authority. Appendix B discusses three other physical coal cleaning and two chemical coal cleaning processes that were selected to represent alternatives to LICADO coal cleaning and no coal cleaning.

This report provides an update on the economics of a CFCTCC plant. Comparisons were made between combined cycle plants fueled with PC, CWM, natural gas and oil, and with a standard $220 \mathrm{MW}$ PC-FGD plant. When compared against the PC-FGD plant, the economics today show C.OE margins for combined cycle plants fueled with PC, CWM, gas and $0 i 1$ of 17.9, 11.0, 10.9 and 9.7 percent, respectively. When coal prices are compared acainst a rising price in gas or oil, the economics immediately become more favorable to a coalfueled based power process. 


\section{PLANT PERfORMANCE}

There are two Reference System power plants -- one fueled by 60/40 coal-water mixture (CWM) and the other fueled by dry pulverized coal (PC). Each plant is a combustion turbine combined cycle, in which power is generated by two gas turbines, one steam turbine and two heat recovery steam generators (HRSGs). This configuration combines the low cost of domestic coal with the high efficiency of a gas turbine combined cycle plant.

The characteristics of the Reference Systems are summarized in Table 2-1 and described in more detail in later sections. Throughout this report, all heating values, heat rates, and efficiencies are calculated on the basis of higher heating value (HHV) of the fuel.

Table 2-1. Reference System Plant Performance

Turbine Fuel

Coal Feed Rate

Limestone Feed Rate

Coal HHV

Plant Thermal Input (HHV)

Gas Turbine Net Power

Steam Turbine Net Power

Plant Auxiliary Power

Net Power Generation

Net Heat Rate (HHV)

Net Electric Efficiency (HHV)
PC

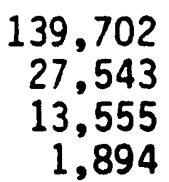

161,304

62,555

$\frac{(2,013)}{221,845}$

8,536

40.0
$60 / 40$ CWM

$\begin{array}{rl}152,289 & 1 \mathrm{~b} / \mathrm{h} \\ 30,025 & 1 \mathrm{~b} / \mathrm{h} \\ 13,555 & \text { Btu/1b } \\ 2,064 & \text { MMBtu/h }\end{array}$

$172,136 \quad \mathrm{~kW}$

$63,917 \quad \mathrm{~kW}$

$\frac{(4,736)}{231,316} \quad \mathrm{~kW}$

8,924

38.2
Btul:kWh

Figure 2.1 is a schematic representation of the physical configuration of the Reference System. Some of the thermal subsystems, such as combustors, cyclones, and gas turbines, consist of multiple components arranged in parallel. In order to facilitate comparisons with other power systems, all performance and cost values in this report are the combined values for all parallel streams unless otherwise specified.

\subsection{Assumptions}

The technical assumptions on which the current standard Westinghouse CFCTCC is based include: using Pittsburgh No. $8 \mathrm{coal}$ (standard utility grade); ambient conditions of $14.7 \mathrm{psia}, 59^{\circ} \mathrm{F}$, and a relative humidity of $60 \%$; NSPS emissions criteria; use of a slagging combustor whose rich/lean zone reduces $\mathrm{NO}_{\mathrm{X}}$ formation; use of limestone as a sorbent to capture sulfur $(\mathrm{Ca} / \mathrm{S}=2)$; use of slagging cyclone to reduce particulate matter and solid alkali; combustor out let temperature of $1850^{\circ} \mathrm{F}$; maximum turbine metal temperature of $1650^{\circ} \mathrm{F}$; pressure drop of $7 \%$ through the slagging combustor system; and, partial recovery of the combustor heat loss of $8 \%$. 
It should be noted that the combustor outlet temperature (COT) is a convenient thermodynamic parameter for system analysis, but it is not the same as the turbine inlet temperature (TIT). The TIT is defined as the fiow-weighted mean total temperature of the working fluid relative to a stationary plane immediately upstream of the first stage rotor blade. For cooled turbines, the COT is higher than the TIT.

\subsection{Performance}

Although the performance of the two Reference Systems are similar, as shown in Table 2-1, the Reference System fueled by coal-water mixture generates 4.3 percent more power at a 4.6-percent worse heat rate than the system fueled by dry coal. The increased power is due to the added turbine mass flow provided by the slurry water. But the evaporation of the water uses some of the thermal energy of the coal, resulting in reduced efficiency.

Figures 2-2 through 2-6 are the flowsheets for both Reference Systems. The numbered streams on the flowsheets correspond to the locations listed in Tables 2-2 and 2-3, which contain thermodynamic data for the streams for the CWM fueled reference system and dry coal-fueled Reference System, respectively. The arithmetic signs $+/-$ of the flows in the data tables correspond to flow directions in the accompanying flow diagrams. The negative flow in stream 89 indicates that steam is extracted from the LP steam turbine, rather than inducted to it.

The electric power generation and use in both systems are compared in Table 2-4. Tables 2-5 and 2-6 are the energy and material balances for the two Reference Systems. The radiation losses listed in the energy balances represent $8.4 \%$ of the lower heating value energy of the coal fuel, and include all losses associated with the slagging combustor, slag disposal systems, connecting duct, and ancillary cleanup equipment. 


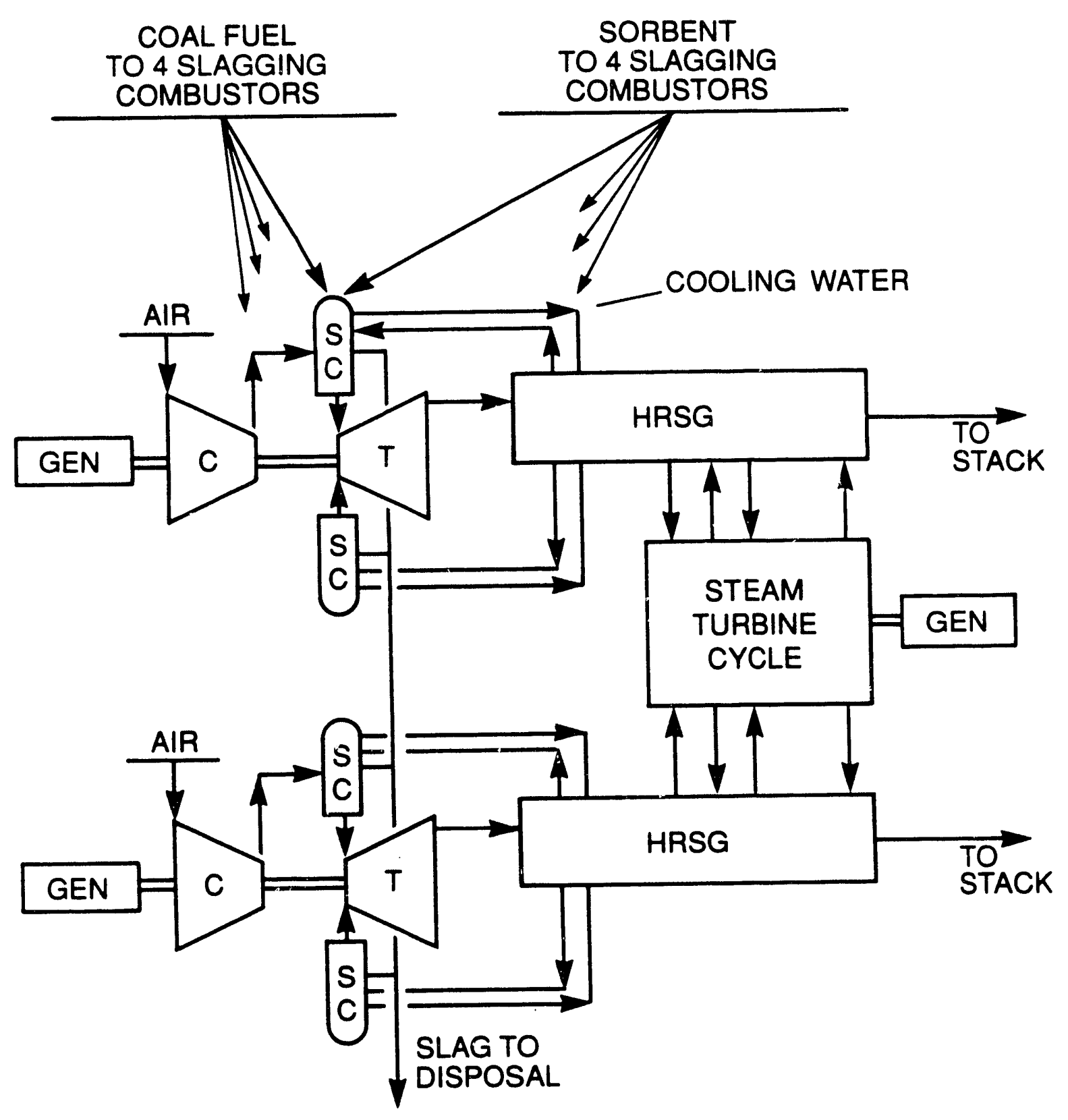

Figure 2-1. Power System Arrangement 


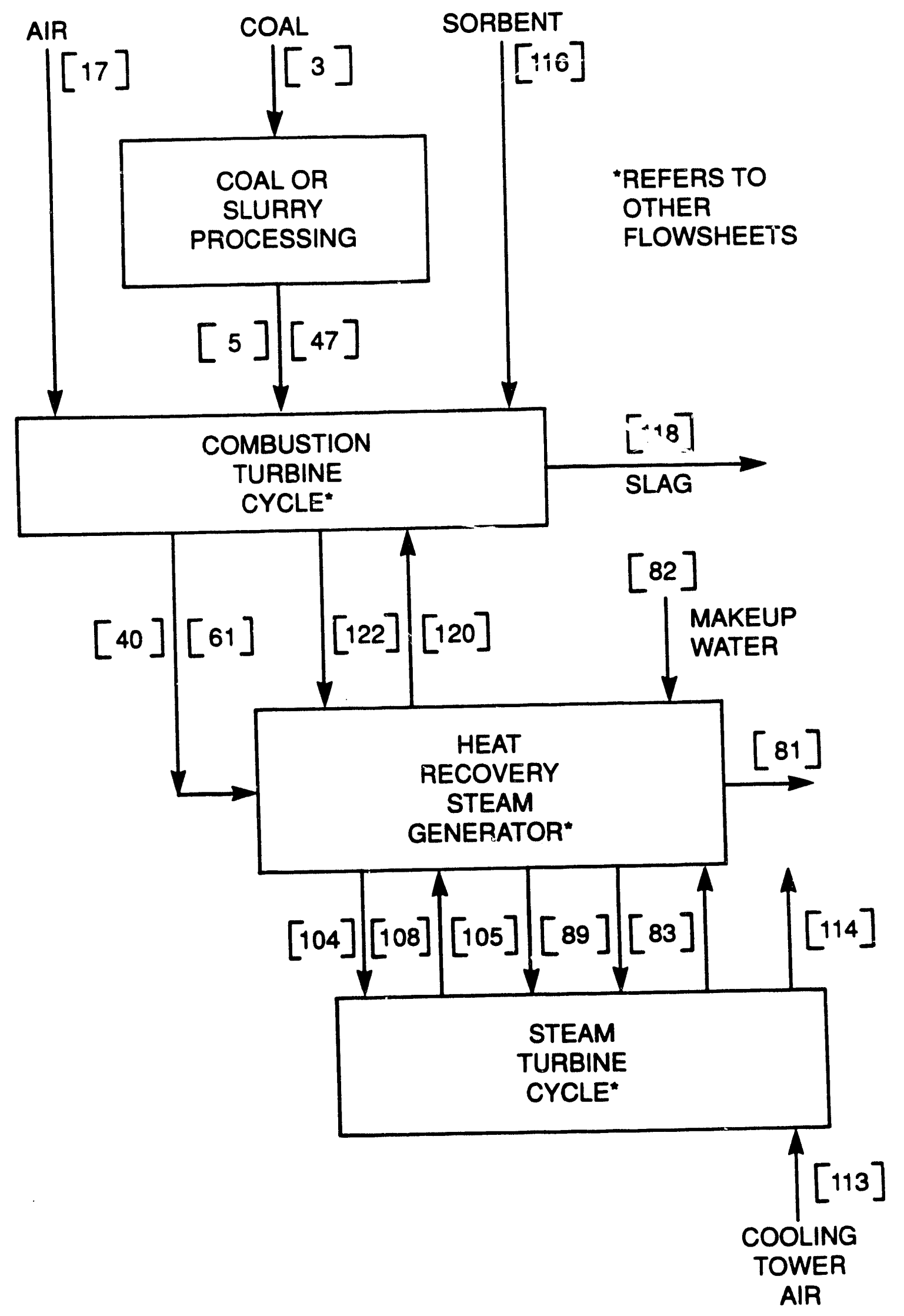

Figure 2-2. Block Flow Diagram - Direct Coai-Fueled Combined Cycle

$2-4$ 


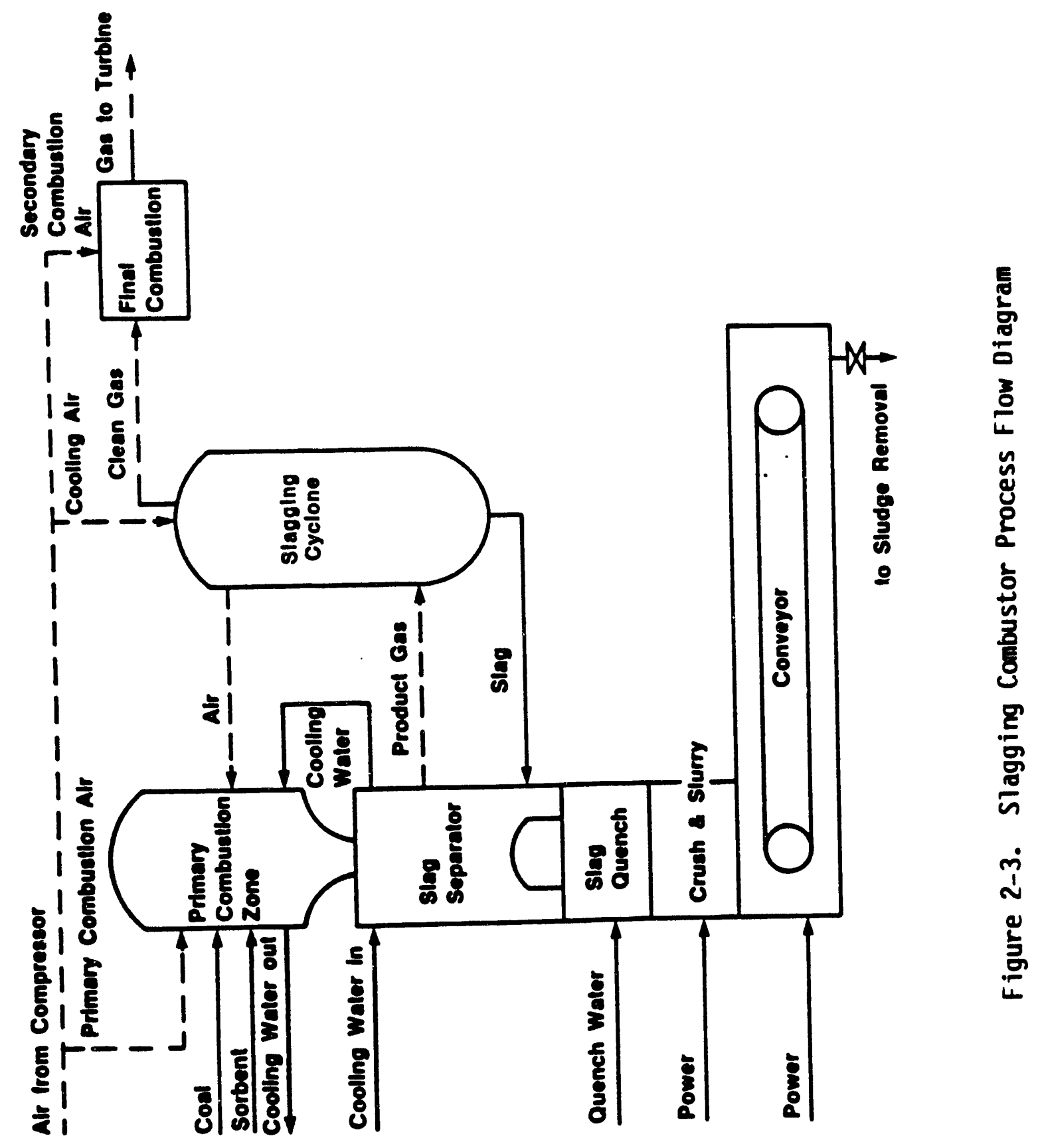




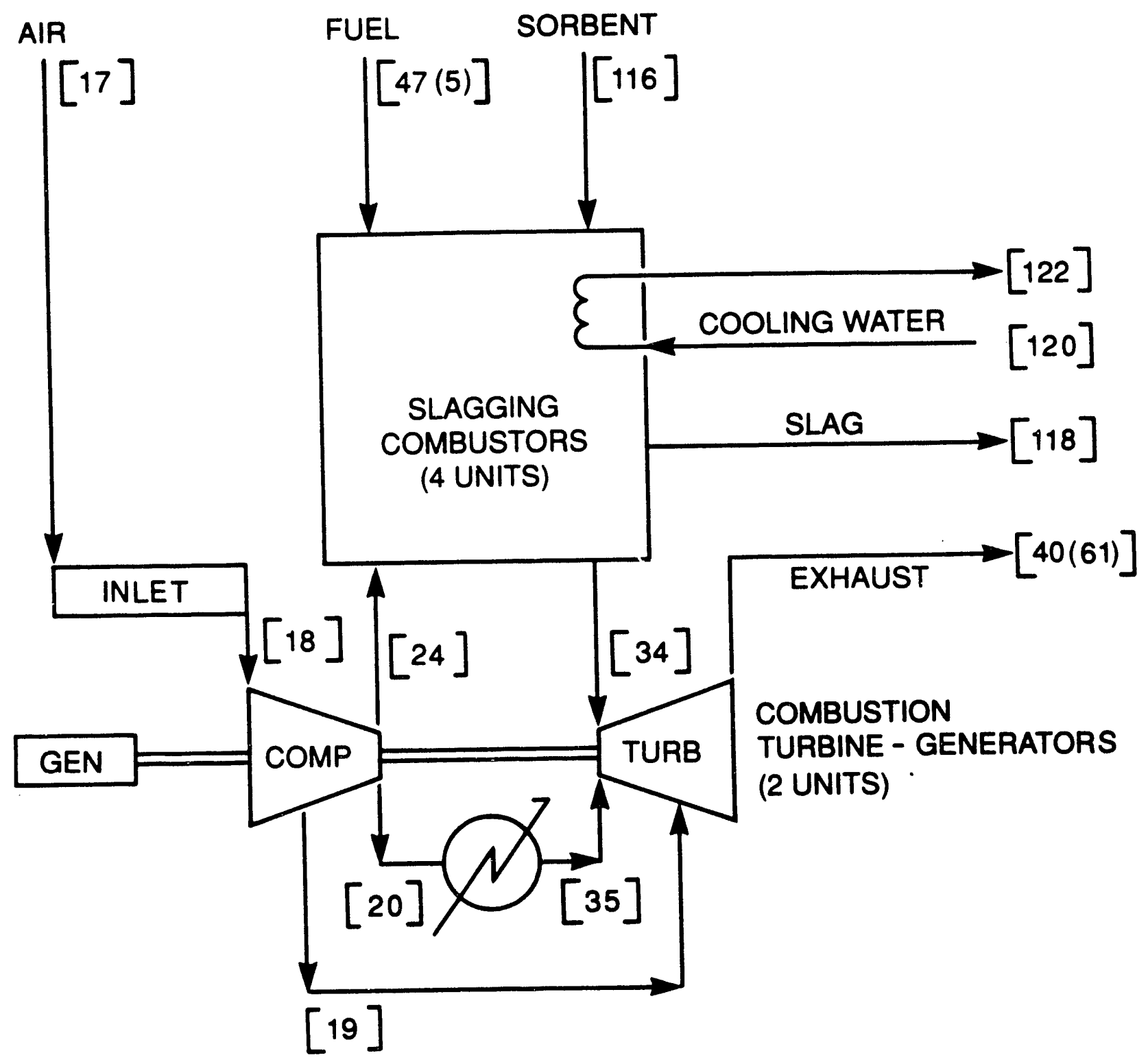

Figure 2-4. Coibustion Turbine Cycle 


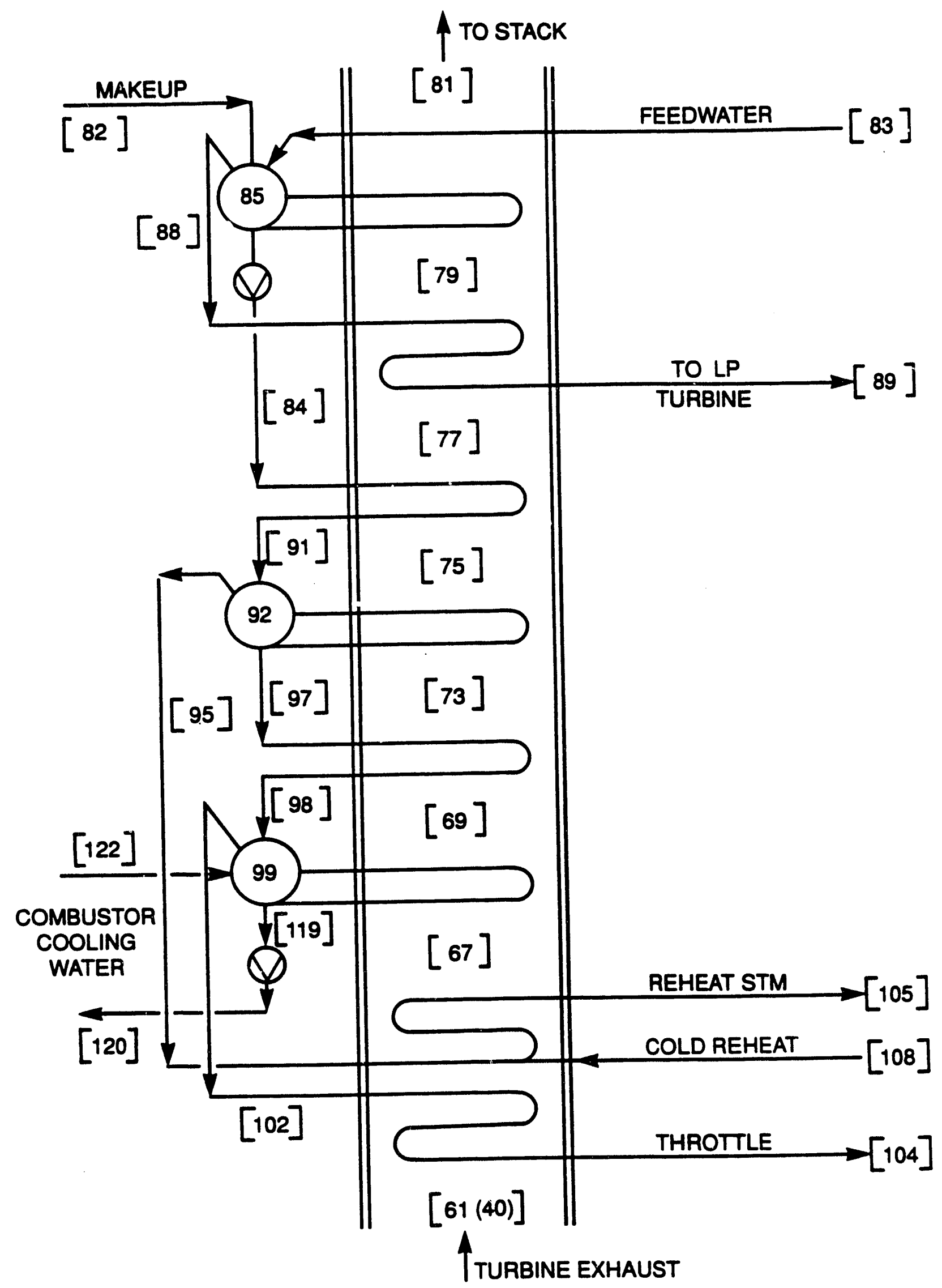

Figure 2-5. Heat Recovery Steam Generator 


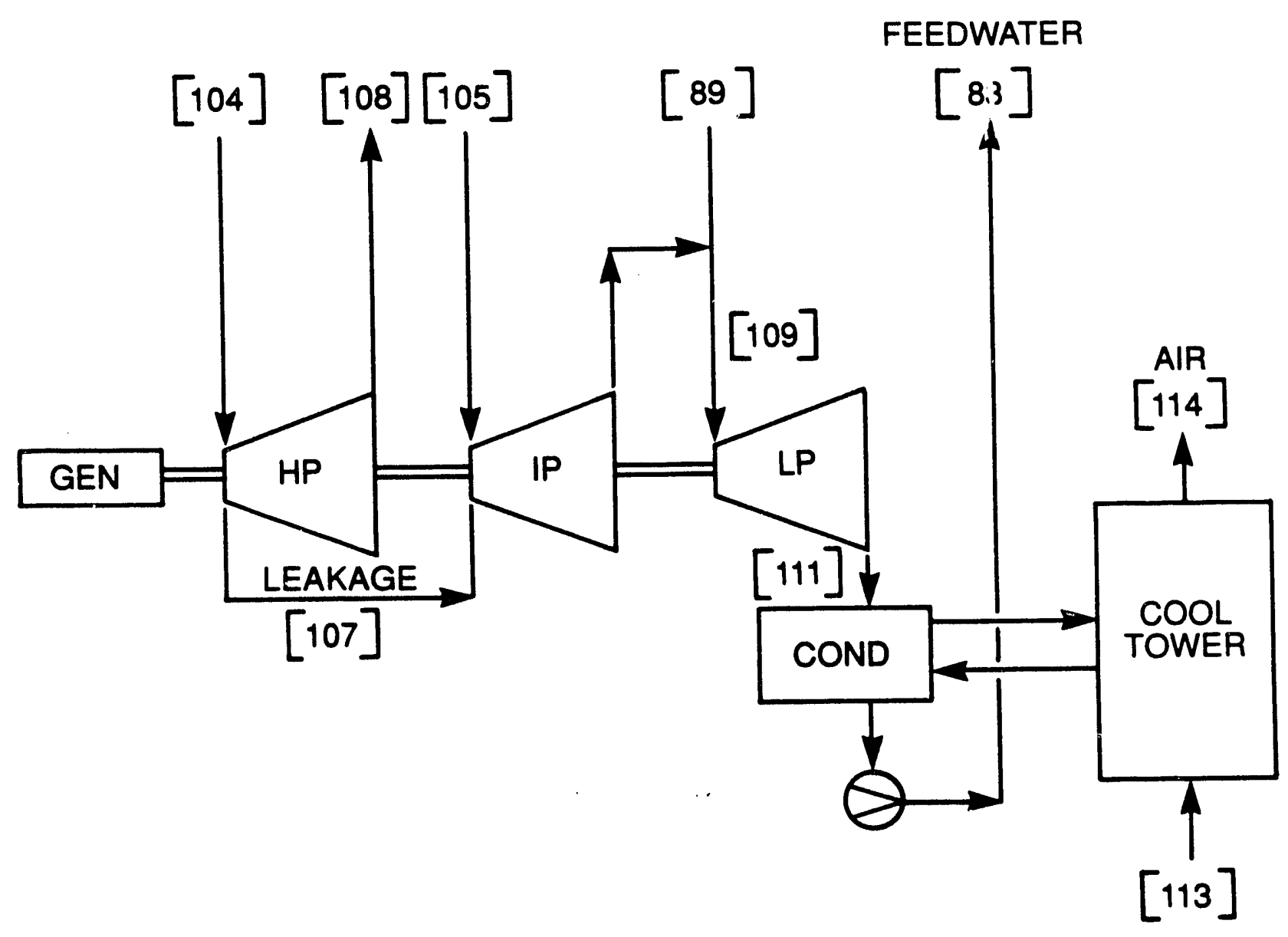

Figure 2-6. Stean Turbine Cycle 
Table 2-2. CWM Coal-Fueled Combined Cycle Thermodynamic Data

\begin{tabular}{|c|c|c|c|c|c|c|c|}
\hline$O C$ & DESCRIPTION & $\begin{array}{l}\text { ENTHAL } \\
\text { BTU/LB }\end{array}$ & $\begin{array}{r}\text { PRESS } \\
\text { PSIA }\end{array}$ & $\begin{array}{c}\text { QUAL } \\
-\end{array}$ & $\begin{array}{l}\text { SPVOL } \\
\text { CUFT/LB }\end{array}$ & $\begin{array}{r}\text { TEMP } \\
F\end{array}$ & $\begin{array}{r}\text { WTFLLO } \\
\mathrm{LB} / \mathrm{H}\end{array}$ \\
\hline $\begin{array}{l}1 \\
2 \\
3 \\
4 \\
5 \\
6 \\
7 \\
8 \\
9 \\
10 \\
11 \\
12 \\
13 \\
14 \\
15 \\
16 \\
17 \\
18 \\
19 \\
20 \\
21 \\
22 \\
23 \\
24 \\
25 \\
26 \\
27 \\
28 \\
29 \\
30 \\
31 \\
32 \\
33 \\
34 \\
35 \\
36 \\
37 \\
38 \\
39 \\
40 \\
41 \\
42 \\
43\end{array}$ & $\begin{array}{l}\text { LP Comp Air Exit } \\
\text { HP Comp Air Inlt } \\
\text { HP Conp LP Coolg } \\
\text { HP Comp HP Coolg } \\
\text { HP Comp Air Exit } \\
\text { HP Brnr Air Inlt } \\
\text { HP Brnr Gas Exit } \\
\text { HP Turb HP Coolg } \\
\text { HP Turb LP Coolg } \\
\text { HP Expander Exit } \\
\text { LP Brnr Gas Exit } \\
\text { LP Turb HP Coolg } \\
\text { LP Turb LP Coolg }\end{array}$ & $\begin{array}{r}28.52 \\
19.56 \\
75.02 \\
.00 \\
75.02 \\
.00 \\
.00 \\
.00 \\
.00 \\
.00 \\
.10 \\
.00 \\
.00 \\
.00 \\
.00 \\
.00 \\
28.52 \\
28.52 \\
137.98 \\
190.24 \\
.00 \\
.00 \\
.00 \\
190.24 \\
190.24 \\
.00 \\
.00 \\
190.24 \\
190.24 \\
.00 \\
.00 \\
.00 \\
190.24 \\
517.65 \\
171.52 \\
137.98 \\
.00 \\
.00 \\
.00 \\
195.11 \\
.00 \\
.00 \\
195.11 \\
.00\end{array}$ & $\begin{array}{r}14.70 \\
14.70 \\
.00 \\
.00 \\
.00 \\
.00 \\
.00 \\
.00 \\
.00 \\
.00 \\
.00 \\
.00 \\
.00 \\
.00 \\
.00 \\
.00 \\
14.70 \\
14.55 \\
105.30 \\
203.69 \\
.00 \\
.00 \\
.00 \\
199.30 \\
199.30 \\
.00 \\
.00 \\
199.30 \\
199.30 \\
.00 \\
.00 \\
.00 \\
199.30 \\
185.35 \\
202.76 \\
103.24 \\
.00 \\
.00 \\
.00 \\
15.13 \\
.00 \\
.00 \\
15.13 \\
.00\end{array}$ & $\begin{array}{l}.00 \\
.00 \\
.00 \\
.00 \\
.00 \\
.00 \\
.00 \\
.00 \\
.00 \\
.00 \\
.00 \\
.00 \\
.00 \\
.00 \\
.00 \\
.00 \\
.00 \\
.00 \\
.00 \\
.00 \\
.00 \\
.00 \\
.00 \\
.00 \\
.00 \\
.00 \\
.00 \\
.00 \\
.00\end{array}$ & $\begin{array}{r}13.13 \\
.02 \\
.00 \\
.00 \\
.01 \\
.00 \\
.00 \\
.00 \\
.00 \\
.00 \\
.00 \\
.00 \\
.00 \\
.00 \\
.00 \\
.00 \\
13.13 \\
13.26 \\
3.41 \\
2.14 \\
.00 \\
.00 \\
.00 \\
2.14 \\
2.14 \\
.00 \\
.00 \\
2.14 \\
2.14 \\
.00 \\
.00 \\
.00 \\
2.14 \\
4.63 \\
2.14 \\
3.41 \\
.00 \\
.00 \\
.00 \\
31.56 \\
.00 \\
.00 \\
28.81 \\
.00\end{array}$ & $\begin{array}{r}59.00 \\
51.46 \\
59.00 \\
.00 \\
59.00 \\
.00 \\
60.00 \\
.00 \\
.00 \\
.00 \\
.00 \\
.00 \\
.00 \\
.00 \\
.00 \\
.00 \\
59.00 \\
59.00 \\
507.05 \\
714.06 \\
.00 \\
.00 \\
.00 \\
714.06 \\
714.06 \\
.00 \\
.00 \\
714.06 \\
714.06 \\
.00 \\
.00 \\
.00 \\
714.06 \\
1850.00 \\
640.50 \\
507.05 \\
.00 \\
.00 \\
.00 \\
713.72 \\
.00 \\
.00 \\
713.72 \\
.00\end{array}$ & $\begin{array}{r}0 . \\
0 . \\
0 . \\
0 . \\
0 . \\
5395896 . \\
5395896 . \\
118845 . \\
393861 . \\
0 . \\
0 . \\
0 . \\
4883190 . \\
4883190 . \\
0 . \\
0 . \\
4883190 . \\
4883190 . \\
0 . \\
0 . \\
0 . \\
4883190 . \\
5130836 . \\
393861 . \\
118845 . \\
0 . \\
0 . \\
0 . \\
5643542 . \\
0 . \\
0 . \\
5643542 .\end{array}$ \\
\hline
\end{tabular}


Table 2-2. CWM Coal-Fueled Combined Cycle Thermodynamic Data

(Cont inued)

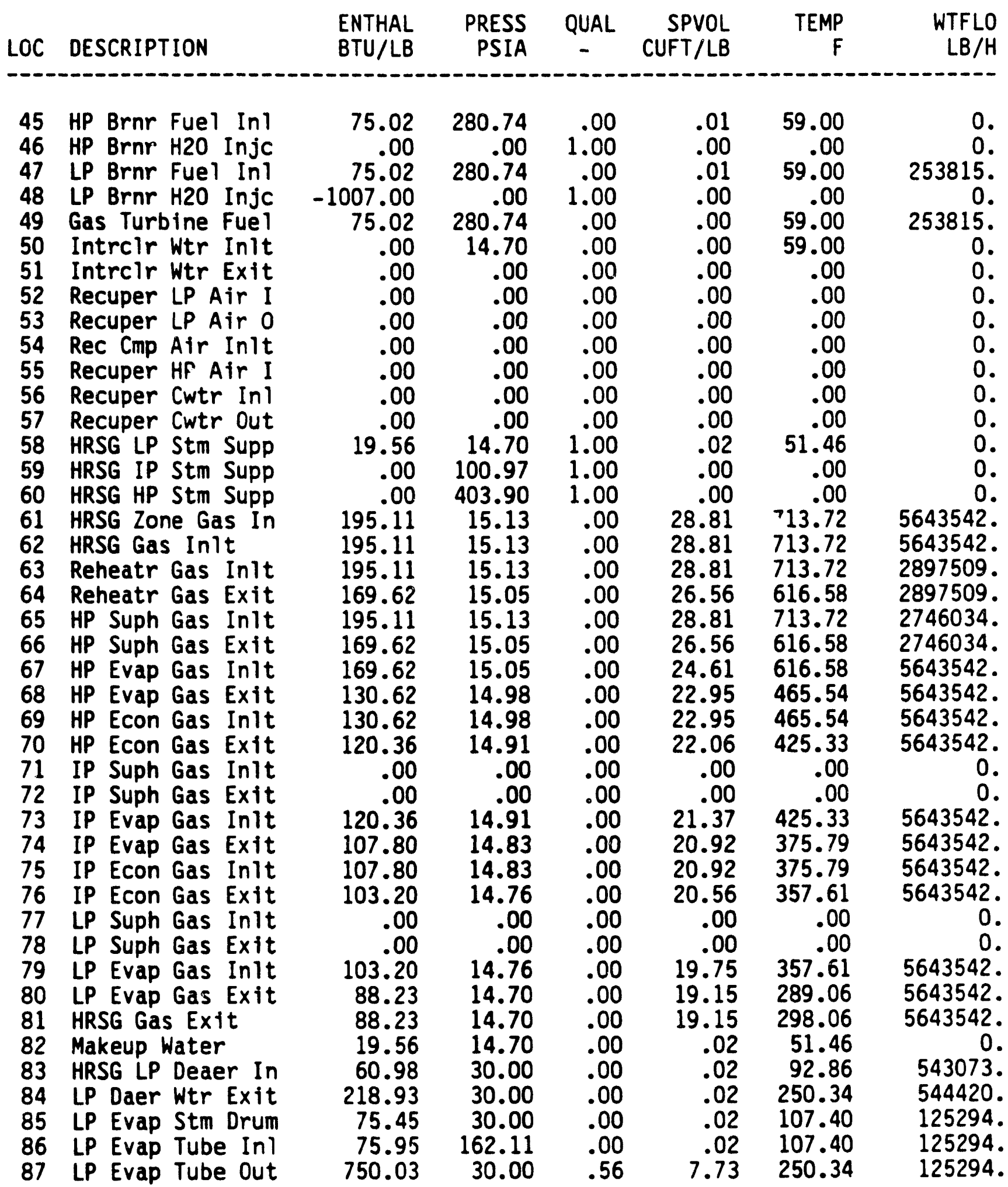


Table 2-2. CWM Coal-Fueled Combined Cycle Thermodynamic Data (Cont inued)

\begin{tabular}{|c|c|c|c|c|c|c|c|}
\hline LOC & DESCRIPTION & $\begin{array}{l}\text { ENTHAL } \\
\text { BTU/LB }\end{array}$ & $\begin{array}{l}\text { PRESS } \\
\text { PSIA }\end{array}$ & QUAL & $\begin{array}{r}\text { SPVOL } \\
\text { CUFT/LB }\end{array}$ & $\begin{array}{r}\text { TEMP } \\
F\end{array}$ & $\begin{array}{r}\text { WTFLO } \\
\text { LB/H }\end{array}$ \\
\hline $\begin{array}{c}88 \\
89 \\
90 \\
91 \\
92 \\
93 \\
94 \\
95 \\
96 \\
97 \\
98 \\
99 \\
100 \\
101 \\
102 \\
103 \\
104 \\
105 \\
106\end{array}$ & $\begin{array}{l}\text { LP Evap Stm Exit } \\
\text { LP Suph Stm Exit } \\
\text { IP Econ Wtr Inlt } \\
\text { IP Evap Wtr Inlt } \\
\text { IP Evap Stm Drum } \\
\text { IP Evap Tube Inl } \\
\text { IP Evap Tube Out } \\
\text { IP Evap Stm Exit } \\
\text { IP suph Stm Exit } \\
\text { HP Econ Wtr Inlt } \\
\text { HP Evap Wtr Inlt } \\
\text { HP Evap Stm Drum } \\
\text { HP Evap Tube In1 } \\
\text { HP Evap Tube Out } \\
\text { HP Evap Stm Exit } \\
\text { Reheatr Stm Inlt } \\
\text { Throttle Steam } \\
\text { Hot Rht Exit } \\
\text { Stm Trb Stm Inlt } \\
\text { Stm Trb HP Leak } \\
\text { HP Stm Trb Exit } \\
\text { Stm Trb Lp Inlet } \\
\text { Stm Trb Stm Exit } \\
\text { Condnsr Stm Inlt } \\
\text { Cndnsr Cnd Exit } \\
\text { Clg Twr Air Inlt } \\
\text { Clg Twr Air Exit } \\
\text { HRSG AB Fuel Gas } \\
\text { Sorbent Inlet } \\
\text { Gas Midpoint } \\
\text { Slag Exit } \\
\text { Slg Clr Pump Inl } \\
\text { Hot Cycl CW Inlt } \\
\text { Slg Comb CW Inlt } \\
\text { Sig Comb CW Exit } \\
\text { Cold Gt Fuel Gas }\end{array}$ & $\begin{array}{r}1164.15 \\
1164.15 \\
220.63 \\
268.25 \\
273.52 \\
274.21 \\
1036.41 \\
1187.34 \\
1187.34 \\
268.25 \\
392.12 \\
393.76 \\
394.25 \\
1140.43 \\
1204.69 \\
1231.89 \\
1354.42 \\
1369.92 \\
1354.42 \\
1354.42 \\
1237.21 \\
1265.14 \\
1053.22 \\
1053.22 \\
60.87 \\
28.52 \\
181.31 \\
.00 \\
.00 \\
.00 \\
551.93 \\
393.76 \\
394.88 \\
394.88 \\
450.72 \\
75.02\end{array}$ & $\begin{array}{r}30.00 \\
30.00 \\
488.72 \\
100.97 \\
100.97 \\
269.88 \\
100.97 \\
100.97 \\
100.97 \\
444.29 \\
403.90 \\
403.90\end{array}$ & $\begin{array}{r}.00 \\
.00 \\
.00 \\
.00 \\
.00 \\
.00 \\
.83 \\
.00 \\
.00 \\
.00 \\
.00 \\
.00 \\
.00 \\
.92 \\
.00 \\
1.00 \\
.00 \\
1.00 \\
1.00 \\
.00 \\
1.00 \\
1.00 \\
.95 \\
.95 \\
.00 \\
.00 \\
.00 \\
.00\end{array}$ & $\begin{array}{r}13.74 \\
13.74 \\
.00 \\
.00 \\
.02 \\
.02 \\
3.65 \\
4.39 \\
4.39 \\
.00 \\
.00 \\
.02 \\
.02 \\
1.06 \\
1.15 \\
5.04 \\
1.77 \\
7.32 \\
1.77 \\
1.77 \\
5.01 \\
18.05 \\
410.19 \\
410.19 \\
.02 \\
.00 \\
.00 \\
.00 \\
.00 \\
.00 \\
.00 \\
.02 \\
.02 \\
.02 \\
.02 \\
.01\end{array}$ & $\begin{array}{r}250.34 \\
250.34 \\
251.08 \\
298.53 \\
303.65 \\
303.65 \\
328.53 \\
328.53 \\
328.53 \\
298.53 \\
415.55 \\
417.05 \\
417.05 \\
445.55 \\
445.55 \\
422.90 \\
680.00 \\
680.00 \\
680.00 \\
680.00 \\
418.77 \\
456.74 \\
92.86 \\
92.86 \\
92.86 \\
59.00 \\
75.88 \\
.00 \\
59.00 \\
.00 \\
1850.00 \\
417.05 \\
417.85 \\
417.85 \\
468.02 \\
59.00\end{array}$ & $\begin{array}{r}-1348 . \\
-1348 . \\
544420 . \\
544420 . \\
92962 . \\
92962 . \\
92962 . \\
77163 . \\
77163 . \\
467257 . \\
467257 . \\
294762 . \\
294762 . \\
294762 . \\
467257 . \\
53575 . \\
467257 . \\
535075 . \\
457912 . \\
9345 . \\
457912 . \\
543073 . \\
543073 . \\
543073 . \\
543073 . \\
3527057 . \\
3527057 . \\
0 . \\
30025 . \\
0 . \\
36193 . \\
2857492 . \\
2857492 . \\
2857492 .\end{array}$ \\
\hline
\end{tabular}

Water Dewpoint $\quad 97.1$

Stack Exit Temp 300.2 
Table 2-3. Dry Coal-Fueled Combined Cycle Thermodynamic Data

\begin{tabular}{|c|c|c|c|c|c|c|c|}
\hline$O C$ & DESCRIPTION & $\begin{array}{l}\text { ENTHAL } \\
\text { BTU/LB }\end{array}$ & $\begin{array}{l}\text { PRESS } \\
\text { PSIA }\end{array}$ & QUAL & $\begin{array}{r}\text { SPVOL } \\
\text { CUFT/LB }\end{array}$ & $\begin{array}{r}\text { TEMP } \\
F\end{array}$ & $\begin{array}{l}\text { WTFLO } \\
\text { LB/H }\end{array}$ \\
\hline $\begin{array}{l}1 \\
2 \\
3 \\
4 \\
5\end{array}$ & $\begin{array}{l}\text { LP Comp Air Exit } \\
\text { HP Comp Air Inlt } \\
\text { HP Comp LP Coolg } \\
\text { HP Comp HP Coolg } \\
\text { HP Comp Air Exit } \\
\text { HP Brnr Air Inlt } \\
\text { HP Brnr Gas Exit } \\
\text { HP Turb HP Coolg } \\
\text { HP Turb LP Coolg } \\
\text { HP Expander Exit } \\
\text { LP Brnr Gas Exit } \\
\text { LP Turb HP Coolg } \\
\text { LP Turb LP Coolg }\end{array}$ & $\begin{array}{r}28.52 \\
19.56 \\
46.08 \\
.00 \\
46.08 \\
.00 \\
.00 \\
.00 \\
.00 \\
.00 \\
.00 \\
.00 \\
.00 \\
.00 \\
.00 \\
.00 \\
28.52 \\
28.52 \\
137.98 \\
190.24 \\
.00 \\
.00 \\
.00 \\
190.24 \\
190.24 \\
.00 \\
.00 \\
190.24 \\
190.24 \\
.00 \\
.00 \\
.00 \\
190.24 \\
510.00 \\
171.52 \\
137.98 \\
.00 \\
.00 \\
.00 \\
192.73 \\
.00 \\
.00 \\
192.73 \\
.00 \\
46.08\end{array}$ & $\begin{array}{r}14.70 \\
14.70 \\
.00 \\
.00 \\
.00 \\
.00 \\
.00 \\
.00 \\
.00 \\
.00 \\
.00 \\
.00 \\
.00 \\
.00 \\
.00 \\
.00 \\
14.70 \\
14.55 \\
105.30 \\
203.69 \\
.00 \\
.00 \\
.00 \\
199.30 \\
199.30 \\
.00 \\
.00 \\
199.30 \\
199.30 \\
.00 \\
.00 \\
.00 \\
199.30 \\
185.35 \\
202.76 \\
103.24 \\
.00 \\
.00 \\
.00 \\
15.13 \\
.00 \\
.00 \\
15.13 \\
.00 \\
280.74\end{array}$ & $\begin{array}{l}.00 \\
.00 \\
.00 \\
.00 \\
.00 \\
.00 \\
.00 \\
.00 \\
.00 \\
.00 \\
.00 \\
.00 \\
.00 \\
.00 \\
.00 \\
.00 \\
.00 \\
.00 \\
.00 \\
.00 \\
.00 \\
.00 \\
.00 \\
.00 \\
.00 \\
.00 \\
.00 \\
.00 \\
.00 \\
.00 \\
.00 \\
.00 \\
.00\end{array}$ & $\begin{array}{r}13.13 \\
.02 \\
.00 \\
.00 \\
.01 \\
.00 \\
.00 \\
.00 \\
.00 \\
.00 \\
.00 \\
.00 \\
.00 \\
.00 \\
.00 \\
.00 \\
13.13 \\
13.26 \\
3.41 \\
2.14 \\
.00 \\
.00 \\
.00 \\
2.14 \\
2.14 \\
.00 \\
.00 \\
2.14 \\
2.14 \\
.00 \\
.00 \\
.00 \\
2.14 \\
4.59 \\
2.14 \\
3.41 \\
.00 \\
.00 \\
.00 \\
31.18 \\
.00 \\
.00 \\
28.60 \\
.00 \\
.01\end{array}$ & $\begin{array}{r}59.00 \\
51.46 \\
60.00 \\
.00 \\
60.00 \\
.00 \\
60.00 \\
.00 \\
.00 \\
.00 \\
.00 \\
.00 \\
.00 \\
.00 \\
.00 \\
.00 \\
59.00 \\
59.00 \\
507.05 \\
714.06 \\
.00 \\
.00 \\
.00 \\
714.06 \\
714.06 \\
.00 \\
.00 \\
714.06 \\
714.06 \\
.00 \\
.00 \\
.00 \\
714.06 \\
1850.00 \\
540.50 \\
507.05 \\
.00 \\
.00 \\
.00 \\
713.73 \\
.00 \\
.00 \\
713.73 \\
.00 \\
60.00\end{array}$ & $\begin{array}{r}0 . \\
0 . \\
139702 . \\
0 . \\
139702 . \\
0 . \\
0 . \\
0 . \\
0 . \\
0 . \\
0 . \\
0 . \\
0 . \\
0 . \\
0 . \\
0 . \\
5395896 . \\
5395896 . \\
117232 . \\
388515 . \\
0 . \\
0 . \\
0 . \\
4890149 . \\
4890149 . \\
0 . \\
0 . \\
4890149 . \\
4890149 . \\
0 . \\
0 . \\
0 . \\
4890149 . \\
5048972 . \\
388515 . \\
117232 . \\
0 . \\
0 . \\
0 . \\
555419 . \\
0 . \\
0 . \\
5554719 .\end{array}$ \\
\hline
\end{tabular}


Table 2-3. Dry Coal-Fueled Combined Cycle Thermodynamic Data (Continued)

\begin{tabular}{|c|c|c|c|c|c|c|c|}
\hline$D C$ & DESCRIPTION & $\begin{array}{l}\text { ENTHAL } \\
\text { BTU/LB }\end{array}$ & $\begin{array}{l}\text { PRESS } \\
\text { PSIA }\end{array}$ & $\begin{array}{l}\text { QUAL } \\
-\end{array}$ & $\begin{array}{r}\text { SPVOL } \\
\text { CUFT/LB }\end{array}$ & $\begin{array}{r}\text { TEMP } \\
F\end{array}$ & $\begin{array}{l}\text { WTFLO } \\
\text { LB/H }\end{array}$ \\
\hline $\begin{array}{l}49 \\
50 \\
51\end{array}$ & $\begin{array}{l}\text { HP Brnr H20 Injc } \\
\text { LP Brnr Fue I Inl } \\
\text { LP Brnr H2O Injc } \\
\text { Gas Turbine Fuel } \\
\text { Intrclr Wtr Inlt } \\
\text { Intrclr Wtr Exit } \\
\text { Recuper LP Air I } \\
\text { Recuper LP Air O } \\
\text { Rec Cmp Air Inlt } \\
\text { Recuper HP Air I } \\
\text { Recuper Cwtr Inl } \\
\text { Recuper Cwtr Out } \\
\text { HRSG LP Stm Supp } \\
\text { HRSG IP Stm Supp } \\
\text { HRSG HP Stm Supp } \\
\text { HRSG Zone Gas In } \\
\text { HRSG Gas InIt } \\
\text { Reheatr Gas Inlt } \\
\text { Reheatr Gas Exit } \\
\text { HP Suph Gas Inlt } \\
\text { HP Suph Gas Exit } \\
\text { HP Evap Gas Inlt } \\
\text { HP Evap Gas Exit } \\
\text { HP Econ Gas Inlt } \\
\text { HP Econ Gas Exit } \\
\text { IP Suph Gas Inlt } \\
\text { IP Suph Gas Exit } \\
\text { IP Evap Gas Inlt } \\
\text { IP Evap Gas Exit } \\
\text { IP Econ Gas Inlt } \\
\text { IP Econ Gas Exit } \\
\text { LP Suph Gas Inlt } \\
\text { LP Suph Gas Exit } \\
\text { LP Evap Gas Inlt } \\
\text { LP Evap Gas Exit } \\
\text { HRSG Gas Exit } \\
\text { Makeup Water } \\
\text { HRSG LP Deaer In } \\
\text { LP Daer Wtr Exit } \\
\text { LP Evap Stm Drum } \\
\text { LP Evap Tube Inl } \\
\text { LP Evap Tube Out } \\
\text { LP Evap Stm Exit }\end{array}$ & $\begin{array}{r}.00 \\
46.08 \\
-31.68 \\
46.08 \\
.00 \\
.00 \\
.00 \\
.00 \\
.00 \\
.00 \\
.00 \\
.00 \\
19.56 \\
.00 \\
-31.68 \\
192.73 \\
192.73 \\
192.73 \\
167.38 \\
192.73 \\
167.38 \\
167.38 \\
129.06 \\
129.06 \\
118.36 \\
.00 \\
.00 \\
118.36 \\
105.30 \\
105.30 \\
100.51 \\
.00 \\
.00 \\
100.51 \\
84.71 \\
84.71 \\
19.56 \\
60.98 \\
218.93 \\
75.58 \\
76.11 \\
762.28 \\
1164.15\end{array}$ & $\begin{array}{r}.00 \\
280.74 \\
280.74 \\
280.74 \\
14.70 \\
.00 \\
.00 \\
.00 \\
.00 \\
.00 \\
.00 \\
.00 \\
14.70 \\
100.97 \\
403.90 \\
15.13 \\
15.13 \\
15.13 \\
15.05 \\
15.13 \\
15.05 \\
15.05 \\
14.98 \\
14.98 \\
14.91 \\
.00 \\
.00 \\
14.91 \\
14.83 \\
14.83 \\
14.76 \\
.00 \\
.00 \\
14.76 \\
14.70 \\
14.70 \\
14.70 \\
30.00 \\
30.00 \\
30.00 \\
172.22 \\
30.00 \\
30.00\end{array}$ & $\begin{array}{r}1.00 \\
.00 \\
1.00 \\
.00 \\
.00 \\
.00 \\
.00 \\
.00 \\
.00 \\
.00 \\
.00 \\
.00 \\
1.00 \\
1.00 \\
1.00 \\
.00 \\
.00 \\
.00 \\
.00 \\
.00 \\
.00 \\
.00 \\
.00 \\
.00 \\
.00 \\
.00 \\
.00 \\
.00 \\
.00 \\
.00 \\
.00 \\
.00 \\
.00 \\
.00 \\
.00 \\
.00\end{array}$ & $\begin{array}{r}.02 \\
.01 \\
.0 ? \\
.01 \\
.00 \\
.00 \\
.00 \\
.00 \\
.00 \\
.00 \\
.00 \\
.00 \\
.02 \\
.00 \\
.02 \\
28.60 \\
28.60 \\
28.60 \\
26.35 \\
28.60 \\
26.35 \\
24.61 \\
22.78 \\
22.78 \\
21.84 \\
.00 \\
.00 \\
21.28 \\
20.65 \\
20.65 \\
20.26 \\
.00 \\
.00 \\
19.55 \\
18.76 \\
18.76 \\
.02 \\
.02 \\
.02 \\
.02 \\
.02 \\
7.91 \\
13.74\end{array}$ & $\begin{array}{r}.00 \\
60.00 \\
.00 \\
60.00 \\
59.00 \\
.00 \\
.00 \\
.00 \\
.00 \\
.00 \\
.00 \\
.00 \\
51.46 \\
.00 \\
.00 \\
713.73 \\
713.73 \\
713.73 \\
615.87 \\
713.73 \\
615.87 \\
615.87 \\
465.54 \\
465.54 \\
423.05 \\
.00 \\
.00 \\
423.05 \\
370.89 \\
370.89 \\
351.68 \\
.00 \\
.00 \\
351.68 \\
288.01 \\
288.01 \\
51.46 \\
92.86 \\
250.34 \\
107.53 \\
107.53 \\
250.34 \\
250.34\end{array}$ & $\begin{array}{r}0 . \\
139702 . \\
24779 . \\
139702 . \\
0 . \\
0 . \\
0 . \\
0 . \\
0 . \\
0 . \\
0 . \\
0 . \\
-24779 \\
0 . \\
24779 . \\
5554719 . \\
5554719 . \\
2865183 . \\
2865183 . \\
2689536 . \\
2689536 . \\
5554719 . \\
5554719 . \\
5554719 . \\
5554719 . \\
0 . \\
0 . \\
5554719 . \\
5554719 . \\
5554719 . \\
5554719 . \\
0 . \\
0 . \\
5554719 . \\
5554719 . \\
5554719 \\
24779 . \\
532607 \\
558763 . \\
127828 \\
127828 \\
127828 \\
-1377\end{array}$ \\
\hline
\end{tabular}


Table 2-3. Dry Coal-Fueled Combined Cycle Thermodynamic Data (Cont inued)

\begin{tabular}{|c|c|c|c|c|c|c|c|}
\hline LOC & DESCRIPTION & $\begin{array}{l}\text { ENTHAL } \\
\text { BTU/LB }\end{array}$ & $\begin{array}{r}\text { PRESS } \\
\text { PSIA }\end{array}$ & $\underset{-}{\text { QUAL }}$ & $\begin{array}{r}\text { SPVOL } \\
\text { CUFT/LB }\end{array}$ & $\begin{array}{r}\text { TEMP } \\
\mathbf{F}\end{array}$ & $\begin{array}{r}\text { WTFLO } \\
\text { LB/H }\end{array}$ \\
\hline $\begin{array}{c}89 \\
90 \\
91 \\
92 \\
93 \\
94 \\
95 \\
96 \\
97 \\
98 \\
99 \\
100 \\
101 \\
102 \\
103 \\
104 \\
105 \\
106 \\
107 \\
108 \\
109 \\
110 \\
111 \\
112 \\
113 \\
114 \\
115 \\
116 \\
117 \\
118 \\
119 \\
120 \\
121 \\
119\end{array}$ & $\begin{array}{l}\text { LP Suph Stm Exit } \\
\text { IP Econ Wtr Inlt } \\
\text { IP Evap Wtr Inlt } \\
\text { IP Evap Stm Drum } \\
\text { IP Evap Tube Inl } \\
\text { IP Evap Tube Out } \\
\text { IP Evap Stm Exit } \\
\text { IP Suph Stm Exit } \\
\text { HP Econ Wtr Inlt } \\
\text { HP Evap Wtr Inlt } \\
\text { HP Evap Stm Drum } \\
\text { HP Evap Tube Inl } \\
\text { HP Evap Tube Out } \\
\text { HP Evap Stm Exit } \\
\text { Reheatr Stm Inlt } \\
\text { Throttle Steam } \\
\text { Hot Rht Exit } \\
\text { Stm Trb Stm Inlt } \\
\text { Stm Trb HP Leak } \\
\text { HP Stm Trb Exit } \\
\text { Stm Trb LP Inlet } \\
\text { Stm Trb Stm Exit } \\
\text { Condnsr Stm Inlt } \\
\text { Cndnsr Cnd Exit } \\
\text { Clg Twr Air Inlt } \\
\text { Clg Twr Air Exit } \\
\text { Hrsg AB Fuel Gas } \\
\text { Sorbent Inlet } \\
\text { Gas Midpoint } \\
\text { Slag Exit } \\
\text { Slg Clr Pump Inl } \\
\text { Hot Cycl CW Inlt } \\
\text { Slg Comb CW Inlt } \\
\text { Slg Comb CW Exit } \\
\text { Cold Gt Fuel Gas }\end{array}$ & $\begin{array}{r}1164.15 \\
220.63 \\
268.25 \\
273.20 \\
273.93 \\
1045.64 \\
1187.34 \\
1187.34 \\
268.25 \\
392.12 \\
393.67 \\
394.16 \\
1140.43 \\
1204.62 \\
1231.56 \\
1354.42 \\
1369.92 \\
1354.42 \\
1354.42 \\
1237.21 \\
1265.14 \\
1053.21 \\
1053.21 \\
60.87 \\
28.52 \\
181.31 \\
.00 \\
.00 \\
.00 \\
551.93 \\
393.67 \\
394.78 \\
394.78 \\
450.62 \\
46.08\end{array}$ & $\begin{array}{r}30.00 \\
488.72 \\
100.97 \\
100.97 \\
279.80 \\
100.97 \\
100.97 \\
100.97 \\
444.29 \\
403.90 \\
403.90 \\
517.42 \\
403.90 \\
403.90 \\
100.97 \\
367.18 \\
91.80 \\
367.18 \\
367.18 \\
100.97 \\
30.00 \\
.76 \\
.76 \\
.76 \\
14.75 \\
14.70 \\
.00 \\
.00 \\
.00 \\
.00 \\
403.90 \\
659.74 \\
659.74 \\
659.74 \\
.00\end{array}$ & $\begin{array}{l}.00 \\
.00 \\
.00 \\
.00 \\
.00 \\
.84 \\
.00 \\
.00 \\
.00 \\
.00 \\
.00 \\
.00 \\
.92 \\
.00 \\
1.00 \\
.00 \\
1.00 \\
1.00 \\
.00 \\
1.00 \\
1.00 \\
.95 \\
.95 \\
.00 \\
.00 \\
.00 \\
.00\end{array}$ & $\begin{array}{r}13.74 \\
.00 \\
.00 \\
.02 \\
.02 \\
3.69 \\
4.39 \\
4.39 \\
.00 \\
.00 \\
.02 \\
.02 \\
1.06 \\
1.15 \\
5.04 \\
1.77 \\
7.32 \\
1.77 \\
1.77 \\
5.01 \\
18.05 \\
410.19 \\
410.19 \\
.02 \\
.00 \\
.00 \\
.00 \\
.00 \\
.00 \\
.00 \\
.02 \\
.02 \\
.02 \\
.02 \\
.01\end{array}$ & $\begin{array}{r}250.34 \\
251.08 \\
298.53 \\
303.33 \\
303.33 \\
328.53 \\
328.53 \\
328.53 \\
298.53 \\
415.55 \\
416.97 \\
416.97 \\
445.55 \\
445.55 \\
422.90 \\
680.00 \\
680.00 \\
680.00 \\
680.00 \\
418.77 \\
456.74 \\
92.86 \\
92.86 \\
92.86 \\
59.00 \\
75.88 \\
.00 \\
59.00 \\
.00 \\
1850.00 \\
416.97 \\
417.77 \\
417.77 \\
467.94 \\
60.00\end{array}$ & $\begin{array}{r}-1377 . \\
558763 . \\
558763 . \\
93921 . \\
93921 . \\
93921 . \\
78935 . \\
78935 . \\
479828 . \\
479828 . \\
285040 . \\
285040 . \\
285040 . \\
455049 . \\
524883 . \\
455049 . \\
524883 . \\
445948 . \\
9101 . \\
445948 . \\
532607 . \\
532607 . \\
532607 . \\
532607 . \\
3459085 . \\
3459085 . \\
0 . \\
27543 . \\
0 . \\
33202 . \\
2621524 . \\
2621524 . \\
2621524 . \\
2621524 . \\
139702 .\end{array}$ \\
\hline
\end{tabular}

$\begin{array}{lr}\text { Water Dewpoint } & 81.8 \\ \text { Acid Dewpoint } & 238.1\end{array}$ 
Table 2-4. Combined Cycle Power Summary
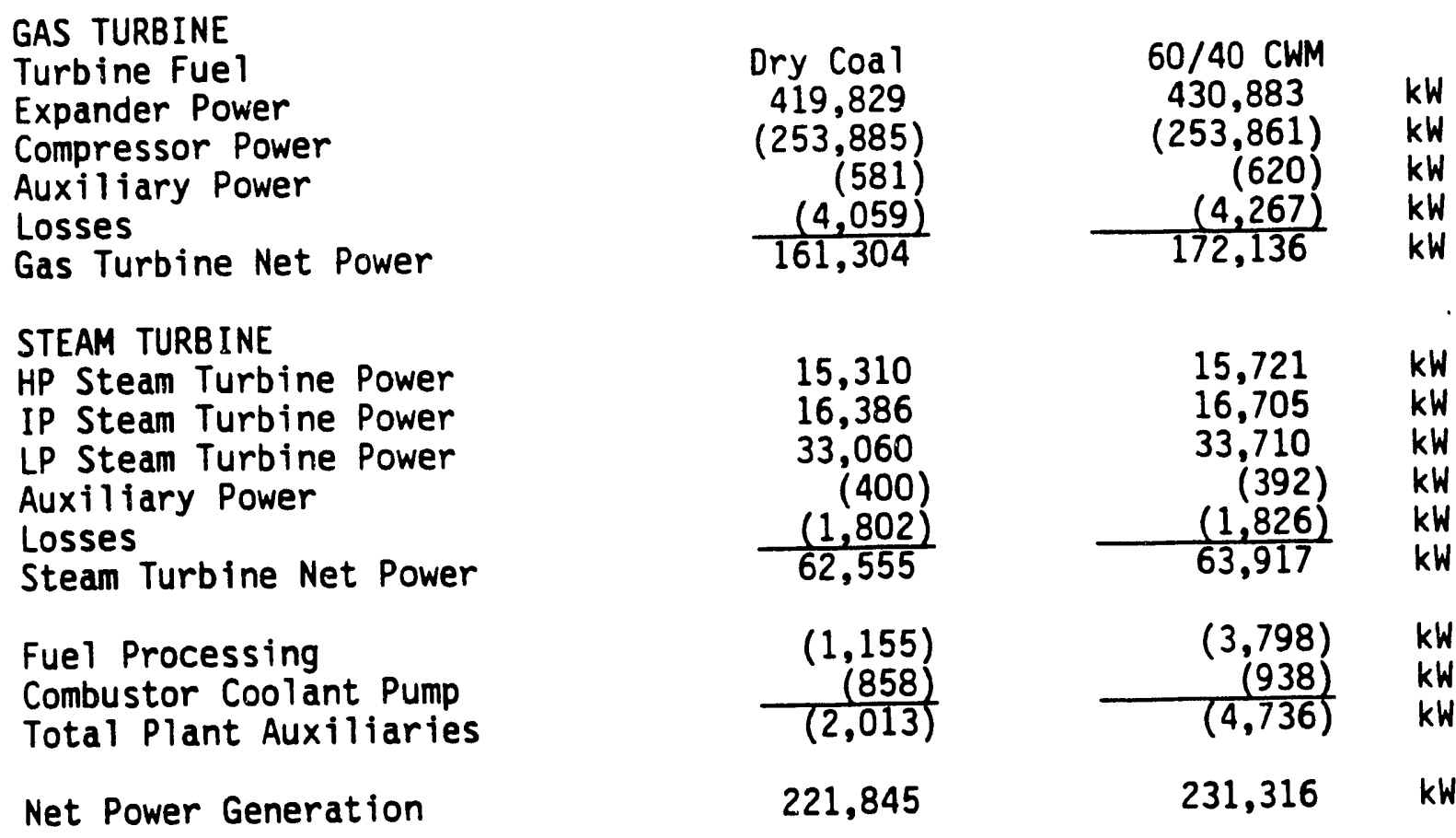

STEAM TURBINE

HP Steam Turbine Power

IP Steam Turbine Power

LP Steam Turbine Power

Auxiliary Power

Losses

Fuel Processing

Combustor Coolant Pump

Net Power Generation
15,310

16,386

33,060

(400)

$\frac{(1,802)}{62,555}$

$\begin{array}{r}(1,155) \\ (858) \\ \hline(2,013)\end{array}$

221,845
kW

$\mathrm{kW}$

$\mathrm{kW}$

k

\begin{tabular}{rr}
15,721 & $\mathrm{~kW}$ \\
16,705 & $\mathrm{~kW}$ \\
33,710 & $\mathrm{~kW}$ \\
$(392)$ & $\mathrm{kW}$ \\
$(1,826)$ & $\mathrm{kW}$ \\
\hline 63,917 & $\mathrm{~kW}$
\end{tabular}

$\begin{array}{rr}(3,798) & \mathrm{kW} \\ (938) & \mathrm{kW} \\ (4,736) & \mathrm{kW}\end{array}$

$231,316 \quad \mathrm{~kW}$

Table 2-5. CWM Combined Cycle Energy Balance

\begin{tabular}{|c|c|c|c|c|c|}
\hline ENERGY INPUTS & LBS/HR & $\begin{array}{c}\text { TEMP } \\
\mathrm{F}\end{array}$ & $\begin{array}{l}\text { ENTHALPY } \\
\text { BTU/LB }\end{array}$ & $\begin{array}{l}\text { MILLIONS } \\
\text { BTU/HR }\end{array}$ & $\begin{array}{l}\text { POWER } \\
\mathrm{kW}\end{array}$ \\
\hline $\begin{array}{l}\text { S1g Clg Wtr Pump } \\
\text { Condensate Pump } \\
\text { Clg Twr Air Fan } \\
\text { Clg Twr Cir. Pump } \\
\text { Stm Trb Gen Loss } \\
\text { Stm Trb Mch Loss } \\
\text { Stm Trb Aux Loss } \\
\text { Boiler Feed Pump } \\
\text { Boiler Circ Pump } \\
\text { Boiler Circ Pump } \\
\text { Boiler Circ Pump } \\
\text { GT Generatr Loss } \\
\text { Slurry Plant } \\
\text { G. Turb Aux Load } \\
\text { G. Turb Mech Loss } \\
\text { LP Air Compressor } \\
\text { Ht Cycl Cooling } \\
\text { Clg Twr Air Inlt } \\
\text { Makeup Water }\end{array}$ & $\begin{array}{r}3527057 \\
0\end{array}$ & $\begin{array}{l}59 . \\
51 .\end{array}$ & $\begin{array}{l}28.52 \\
19.56\end{array}$ & $\begin{array}{r}3.20 \\
.06 \\
.04 \\
.04 \\
3.68 \\
2.26 \\
.29 \\
.93 \\
.06 \\
.06 \\
.15 \\
8.52 \\
12.96 \\
2.11 \\
6.04 \\
866.42 \\
.00 \\
100.57 \\
.00\end{array}$ & $\begin{array}{r}937.5 \mathrm{~kW} \\
17.3 \mathrm{~kW} \\
12.0 \mathrm{~kW} \\
12.3 \mathrm{~kW} \\
1079.2 \mathrm{~kW} \\
661.4 \mathrm{~kW} \\
86.0 \mathrm{~kW} \\
271.0 \mathrm{~kW} \\
18.1 \mathrm{~kW} \\
18.6 \mathrm{~kW} \\
42.7 \mathrm{~kW} \\
2497.2 \mathrm{~kW} \\
3798.3 \mathrm{~kW} \\
619.6 \mathrm{~kW} \\
1770.2 \mathrm{~kW} \\
253860.6 \mathrm{~kW}\end{array}$ \\
\hline
\end{tabular}


Table 2-5. CWM Combined Cycle Energy Balance

(Continued)

\begin{tabular}{|c|c|c|c|c|c|}
\hline ENERGY INPUTS & LBS/HR & $\begin{array}{l}\text { TEMP } \\
\mathrm{F}\end{array}$ & $\begin{array}{l}\text { ENTHALPY } \\
\text { BTU/LB }\end{array}$ & $\begin{array}{l}\text { MILLIONS } \\
\text { BTU/HR }\end{array}$ & $\begin{array}{l}\text { POWER } \\
\mathrm{kW}\end{array}$ \\
\hline $\begin{array}{l}\text { Fuel L.H.V. (Eff.) } \\
\text { Gas Turbine Fuel } \\
\text { Comprsr Air Inlt } \\
\text { G. Turb HP Cooling } \\
\text { siagger Reaction } \\
\text { Sorbent Inlet }\end{array}$ & $\begin{array}{r}253815 \\
5395896 \\
30025\end{array}$ & $\begin{array}{l}59 . \\
59 . \\
59 .\end{array}$ & $\begin{array}{r}75.02 \\
28.52 \\
.00\end{array}$ & $\begin{array}{r}1994.44 \\
19.04 \\
153.87 \\
.00 \\
7.89 \\
.00\end{array}$ & \\
\hline Total & 9206793. & & & 3182.64 & \\
\hline ENERGY INPUTS & LBS/HR & $\underset{\mathrm{F}}{\text { TEMP }}$ & $\begin{array}{l}\text { ENTHALPY } \\
\text { BTU/LB }\end{array}$ & $\begin{array}{l}\text { MILLIONS } \\
\text { BTU/HR }\end{array}$ & $\begin{array}{l}\text { POWER } \\
\text { kW }\end{array}$ \\
\hline $\begin{array}{l}\text { LP Stm Turb } \\
\text { IP Stm Turb } \\
\text { HP Stm Turb } \\
\text { LP Gas Expander } \\
\text { HRSG Gas Exit } \\
\text { Clg Twr Air Exit } \\
\text { Clg Twr Air Fan } \\
\text { Clg Twr Cir. Pump } \\
\text { Stm Trb Gen Loss } \\
\text { Stm Trb Mch Loss } \\
\text { Stm Trb Aux Loss } \\
\text { Gt Generatr Loss } \\
\text { Slurry Plant } \\
\text { G. Turb LP Cooling } \\
\text { Radiation Losses } \\
\text { G. Turb Aux Load } \\
\text { G. Turb Mech Loss } \\
\text { Siagger Lat. Heat } \\
\text { Slag Exit }\end{array}$ & $\begin{array}{l}5643542 \\
3527057\end{array}$ & 298. & $\begin{array}{r}88.23 \\
181.31\end{array}$ & $\begin{array}{r}115.05 \\
57.01 \\
53.65 \\
1470.59 \\
497.91 \\
639.49 \\
.04 \\
.04 \\
3.68 \\
2.26 \\
.29 \\
8.52 \\
12.96 \\
7.37 \\
\star 167.99 \\
2.11 \\
6.04 \\
119.41 \\
19.98\end{array}$ & $\begin{array}{r}33719.1 \mathrm{~kW} \\
16704.6 \mathrm{~kW} \\
15720.8 \mathrm{~kW} \\
430883.2 \mathrm{~kW}\end{array}$ \\
\hline & 9206793. & & & & \\
\hline
\end{tabular}

* Conservative value established under original project ground rules in 1983. Radiation losses include everything in the combustion zone which includes the slagging combustion process. 
Table 2-6. Dry Coal-Fueled Combined Cycle Energy 8:1ance

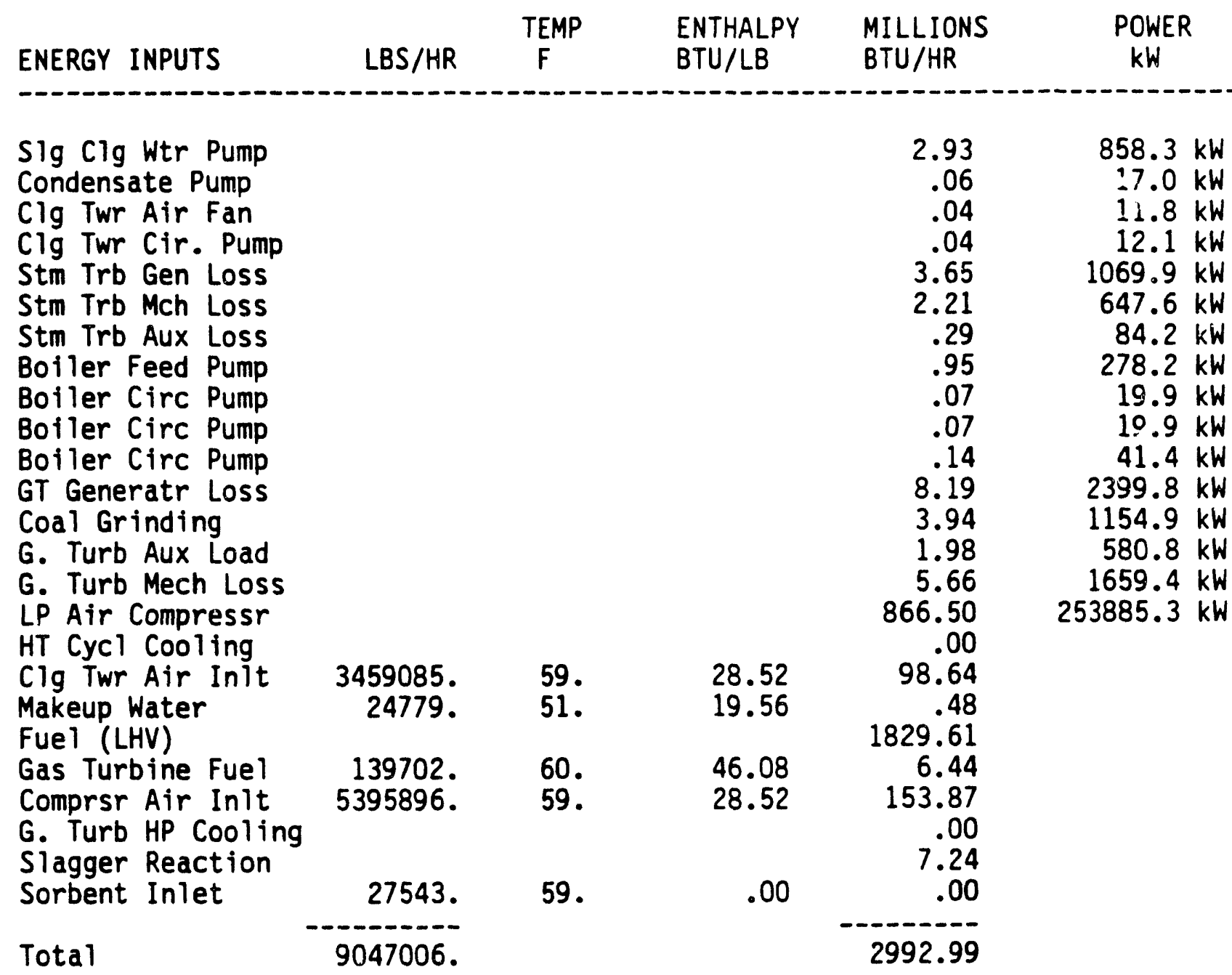

\begin{tabular}{|c|c|c|c|c|c|}
\hline ENERGY INPUTS & LBS/HR & $\begin{array}{l}\text { TEMP } \\
\mathbf{F}\end{array}$ & $\begin{array}{l}\text { ENTHALPY } \\
\text { BTU/LB }\end{array}$ & $\begin{array}{l}\text { MILLIONS } \\
\text { BTU/HR }\end{array}$ & $\begin{array}{l}\text { POWER } \\
\mathrm{kW}\end{array}$ \\
\hline $\begin{array}{l}\text { LP Stm Turb } \\
\text { IP Stm Turb } \\
\text { HP Stm Turb } \\
\text { LP Gas Expander } \\
\text { HRSG Gas Exit } \\
\text { Clg Twr Air Exit } \\
\text { Clg Twr Air Fan } \\
\text { Clg Twr Cir. Pump } \\
\text { Stm Trb Gen Loss } \\
\text { Stm Trb Mch Loss } \\
\text { Stm Trb Aux Loss } \\
\text { Gt Generatr Loss } \\
\text { Coal Grinding }\end{array}$ & $\begin{array}{l}5554719 \\
3459085\end{array}$ & $\begin{array}{c}288 \\
76\end{array}$ & $\begin{array}{r}84.71 \\
181.31\end{array}$ & $\begin{array}{r}112.83 \\
55.93 \\
52.25 \\
1432.86 \\
470.54 \\
627.17 \\
.04 \\
.04 \\
3.65 \\
2.21 \\
.29 \\
8.19 \\
3.94\end{array}$ & $\begin{array}{r}33060.4 \mathrm{~kW} \\
16386.4 \mathrm{~kW} \\
15310.0 \mathrm{~kW} \\
419829.1 \mathrm{~kW}\end{array}$ \\
\hline
\end{tabular}


Table 2-6. Dry Coal-Fueled Combined Cycle Energy Balance (Continued)

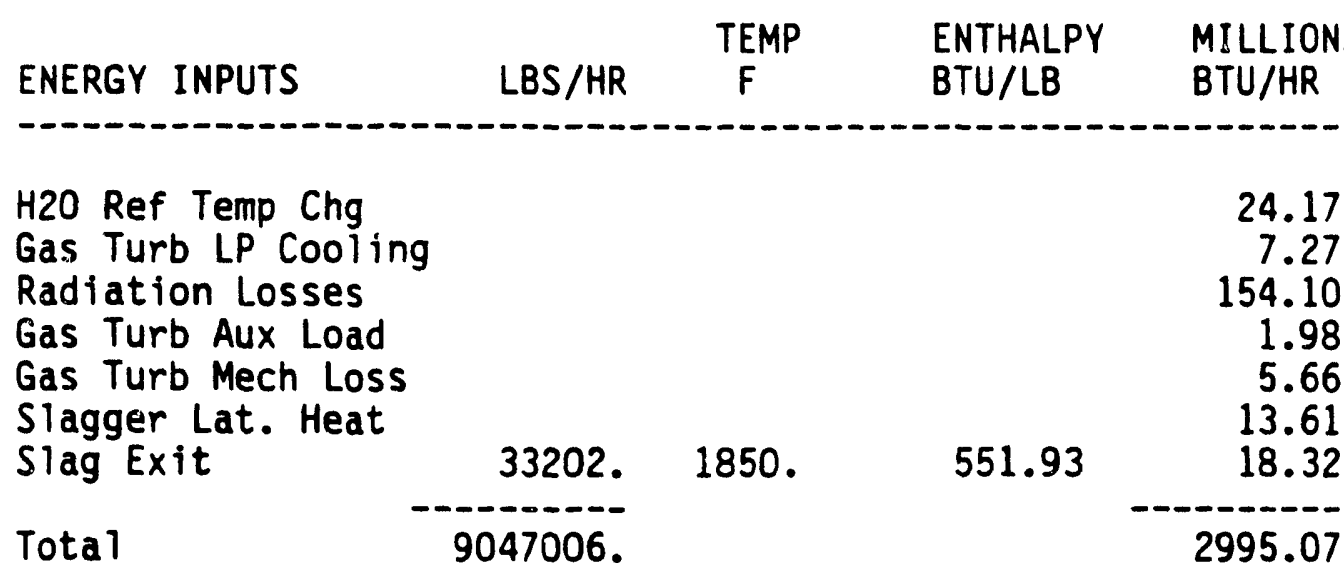

\subsection{Emission Goals}

New Source Performance Standards (NSPS) are assumed to be the emissions criteria. Stipulations of the Code of Federal Regulations, Volume 40, parts 53-60, July 1, 1989 are summarized in Table 2-7, as applied to electric utility boilers. The combined cycle plants burning coal-water slurry are treated as coal-in, electric-power-out plants, so the boiler rules are expected to apply.

\section{Table 2-7. Emissions Goals}

\section{Pollutant Species}

Particulates: Boiler Rule

Opacity: Boiler Rule

Sulfur: Boiler Rule Option 1:

Option 2:

Nitrogen Oxides: Boiler Rule
Maximum Amount

$0.031 \mathrm{~b} / \mathrm{MMBtu}$

20 percent

$1.2 \mathrm{lb} / \mathrm{MMBtu}$, with $90 \%$ reduction in uncontrolled $\mathrm{SO}_{2}$

$0.61 \mathrm{~b} / \mathrm{MMBtu}$, with $70 \%$ reduction in uncontrolled $\mathrm{SO}_{2}$

$0.6 \mathrm{lb} / \mathrm{MMBtu}$ 


\section{ECONOMICS}

\subsection{Economic Assumptions}

The assumptions underlying the economic assessment of the proposed power plant are described in this section. The same assumptions and methods are applied to assuring consistency in the comparisons.

The assumptions are divided into five sections:

- Section 3.1.1 explains the choice of COE as the criterion

- Section 3.1.2 describes the power plant that is being evaluated

- Section 3.1.3 outlines financial assumptions specific to the power plant

- Section 3.1.4 describes the COEs of the conventional plants to which the proposed plant are compared.

\subsubsection{Criterion: Cost of Electricity}

Cost of Electricity (COE) is the basis for financial comparison because it is a powerful tool for comparing the economic merits of competing systems. Although various financing assumptions are possible within the EPRI Technical Assessment Guide, and although resulting COE figures may not represent current utility cost structures, COE evaluates the trade-off between fuel cost (the largest contributor to the levelized COE) and utility capital requirements. $\mathrm{COE}$ is useful because it considers the total plant configuration in the comparative evaluations.

The COE, otherwise known as the levelized busbar cost of electricity, is the sum of six levelized components:

- Carrying Charges (a function of capital cost)

- Fixed Operating and Maintenance Expense

- Variable Operating and Maintenance Expense

- Cost of Consumables

- By-Product Credit (not used in study)

- Fuel Cost

The COE margin, which is the difference between the COE of a candidate system and the COE of a pulverized-coal plant with stack gas cleanup, is the financial indicator. Systems with COE margins above 10 percent could be of commercial interest, but systems with COE margins above 20 percent would definitely draw commercial interest.

The COE calculations are described in greater detail in Section 3.2 .

\subsubsection{Power Plant Definition}

The direct coal-fired power plant, into which the low-emission cleanup system is integrated, is a combustion turbine combined cycle (CFCTCC) fueled with CWM or PC. The combined cycle plant consists of two gas turbines and one reheat steam turbine. The characteristics of the plant are shown in Table $3-1$. This configuration combines the low cost of domestic coal with the high efficiency of a combustion turbine combined cycle plant. 
Table 3-1. Reference System Plant Characteristics

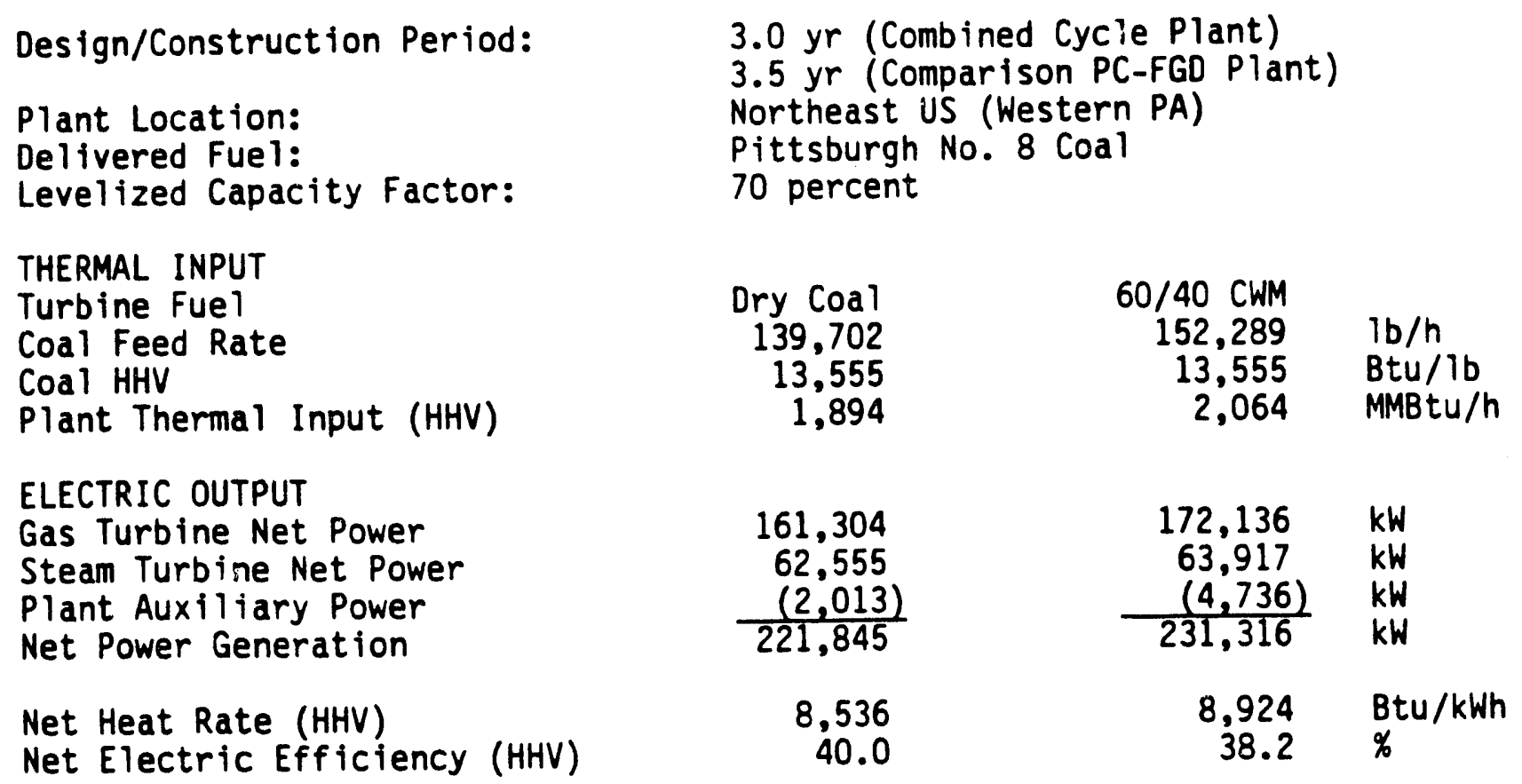

The delivered coal is Pittsburgh No. 8 coal whose ultimate analysis and heating value are given in Table 3-2. On-site fuel preparation consists of conventional grinding and CWM production for the CWM plant, and conventional grinding for the dry coal-fueled plant. There is no cleaning of the coal in either of these processes to remove ash or sulfur before it is burned in the slagging combustor.

Table 3-2. Fuel Characteristics

$\begin{array}{rrrr}60 / 40 & \text { Dry } & \text { No.2 } & \text { Natural } \\ \text { CWM } & \text { Coa } & 017 & \text { Gas }\end{array}$

$\begin{array}{lrrrr}\text { WEIGHT (\%) } & & & & \\ \text { Carbon } & 44.67 & 74.45 & 86-66 & 69.26 \\ \text { Hydrogen } & 2.98 & 4.97 & 12-14 & 22.68 \\ \text { Nitrogen } & 0.91 & 1.51 & <0.1 & 8.06 \\ \text { Oxygen } & 3.70 & 6.17 & - & - \\ \text { Sulfur } & 1.80 & 3.00 & 0.05-1.0 & - \\ \text { Moisture } & 41.51 & 2.51 & - & - \\ \text { Ash/Inert } & 4.43 & 7.39 & - & \\ \text { CONSTITUENTS (\%vol) } & & & & \\ \mathrm{CH}_{4} & & & & \\ \mathrm{C}_{2} \mathrm{H}_{6} & & & & 5.0 \\ \mathrm{~N}_{2} & & & & 5.0 \\ \end{array}$


Table 3-2. Fuel Characteristics (Continued)

$\begin{array}{rrrr}60 / 40 & \text { Dry } & \text { No.2 } & \text { Natural } \\ \text { CWM } & \text { Coa1 } & 0 i 1 & \text { Gas }\end{array}$

HEATING VALUE (Btu/1b)

Higher HV

Lower HV

8,133

7,858

13,555

13,096

$\sim 19,500$

21,799

19,671

The compositions of the sorbents used in this study -- limestone and taconite -- are characterized in Table 3-3.

\section{Table 3-3. Sorbent Constituents}

Limestone

Taconite

WEIGHT (\%)

Calcium Carbonate, $\mathrm{CaCO}_{3}$

Moisture, $\mathrm{H}_{2} \mathrm{O}$

Magnetite, $\mathrm{Fe}_{2} \mathrm{O}_{3}$

Inert Material
95.00

5.00

35.74

64.26

\subsubsection{Plant Financial Data}

The financial assumptions used to compare the economic performance of the direct coal-fired combustion turbine plant with that of the reference pulverized coal plant are summarized here. The same assumptions apply to both plants. Table 3-4 lists the financial assumptions (economics, financing, and taxes) that affect the calculations of carrying charge rate and leveliziny factors.

\section{Table 3-4. Financial Assumptions}

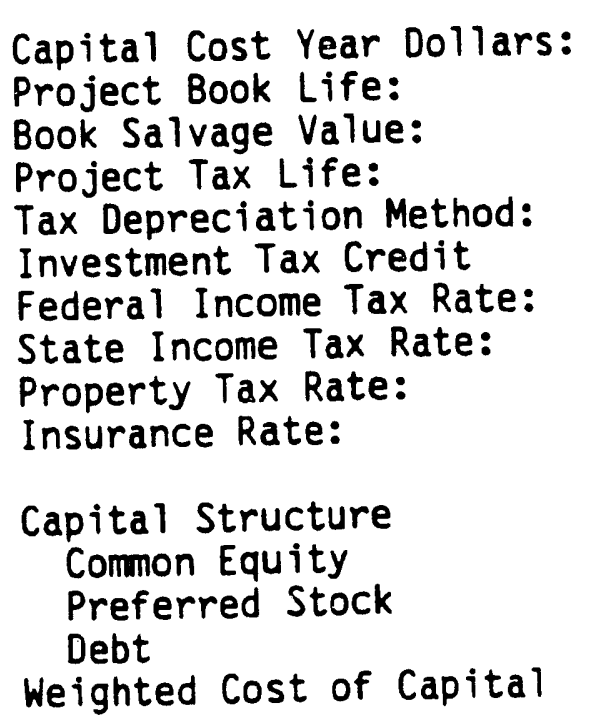

1989 (December)
30 years
-0 -
20 years
Reform
$0 \%$
$34.0 \%$
$4.0 \%$
$1.0 \%$
$1.0 \%$
$\frac{\% \text { of Total }}{35}$
15
50

Cost $(\%)$

15.2

11.5

11.0

12.5 
Table 3-4. Financial Assumptions

(Continued)

Escalation Rates (Apparent)

General Escalation

$6.0 \%$ per year

Fuel Escalation

2.0\% per year

Table 3-5. Operating Costs

ITEM

General Inflation

Interest during Construction

Operating Labor

Pittsburgh No. 8 Coal

Limestone sorbent

Hematite $\left(\mathrm{Fe}_{2} \mathrm{O}_{3}\right)$ sorbent

Magnetite $\left(\mathrm{Fe}_{3} \mathrm{O}_{4}\right)$ sorbent

Taconite $\left(\mathrm{Fe}_{3} \mathrm{O}_{4} \mathrm{w} /\right.$ inerts) sorbent

Nitrogen

Raw Water

Water treatment chemicals

CWM dispersant

CWM stabilizer

CWM pH modifier

Sludge disposal

Solid Waste Disposal
OPERATING COST

$6.0 \%$ per year
$12.5 \%$ per year
$\$ 21.70$ /hr w/burden
$\$ 1.80$ /MMBtu
$\$ 17.20 /$ ton
$\$ 380$ /ton
$\$ 380 /$ ton
$\$ 30 /$ ton
$\$ 96.86 /$ ton
$\$ 0.70 / 1000$ gallons
$\$ 0.12 / 1 \mathrm{~b}$
$\$ 0.24 / 1 \mathrm{~b}$
$\$ 2.75 / 1 \mathrm{~b}$
$\$ 0.167 / 1 \mathrm{~b}$
$\$ 10.60$ /ton
$\$ 9.20 /$ ton

Table 3-5 shows the assumed values for process flow costs of the power plant.

\subsubsection{COE of Conventional Plants}

The cost of a conventional PC-FGD plant, and of a CTCC plant provides economic reference points for the evaluation of CFCTCC plants. For consistency in comparisons, the reference cost data was developed for 220 MWe PC-FGD plants. The design values on which the costs were based reflect generic design conditions. Table 3-6 summarizes the design conditions of the conventional plant designs.

Table 3-6. Conventional Plants - Design Conditions (HHV)

Plant Type

Plant Output, MW

Fuel Type

Fuel HHV, Btu

Plant Heat Rate, Btu/kWh

Boiler

Steam Turbine Generator [1]

Cooling Tower [2]
PC-FGD

220

Pgh. 8 Coal

$13,555 / 16$

9,960

Subcrit

$\mathrm{TC} / 2 \mathrm{~F}$

MD, Wet
CTCC, gas

Nat Gas

$1,035 / \mathrm{SCF}$

8,208

Subcrit

$\mathrm{TC} / 2 \mathrm{~F}$

$M D$, Wet
CTCC, 0 il 258

No. 2011 $138,690 / \mathrm{ga} 1$ 8,227

Subcrit $\mathrm{TC} / 2 \mathrm{~F}$

MD, Wet 
Table 3-6. Conventional Plants - Design Conditions

(Continued)

Sulfur Control System

Fuel cost, \$/MMBtu

Construction Time, yrs

Book Life, yrs

TPC Year

TPI Year

Capacity Factor
Limestone FGD

$\$ 1.80$

3.5

30

Dec 1989

Jan 1990

$70 \%$ none
$\$ 4.00$

2.0

30

Dec 1989

Jan 1990

$70 \%$ none

$\$ 4.00$

2.0

30

Dec 1989

Jan 1990

[1] Tandem Compound, Double Flow

[2] Mechanical Draft, Wet

All costs for the PC-FGD and CTCC plants were developed with the same cost basis as for the CFCTCC plants. These cost items are discussed in greater detail in Section 3.2. The conventional cost estimates are for complete PCFGD and CTCC plants, including all equipment, materials, labor, and construction support.

Tables 3-7 and 3-8 summarize the capital and operating costs, respectively, for the conventional power plants. The Total Plant Investment (TPI) includes allowances for funds used during construction, as explained in Section 3.2.2.

The levelized busbar COE of these plants, summarized in Table 3-9 are the reference values to which all other plants in this study are compared.

The COE is calculated by dividing the total annual capital and operating costs (levelized) by the total annual electric production. Calculation procedures are explained in Section 3.5.

The capital and O\&M costs of the PC-FGD plant are about three times the cost of either combined cycle plant, and its capital and O\&M charges are correspondingly higher. On the other hand, the annual fuel cost for coal is only about a third of the annual cost of either oil or natural gas. The net result

of these differences is that combined cycle plants in base-loaded operation can produce electricity at a lower cost than can conventional pulverized coal plants.

\section{Table 3-7. Conventional Plants - Capital Requirements}

$\begin{array}{lrrr}\text { Plant Type } & \text { PC-FGD } & \text { CTCC, gas } & \text { CTCC, oil } \\ \text { CAPITAL INVESTMENT } & (\$ / \mathrm{kW}) & (\$ / \mathrm{kW}) & (\$ / \mathrm{kW}) \\ \text { Process Capita1 \& Facilities } & 1255.2 & 444.0 & 454.4 \\ \text { Engrg \& H.0. Fee } & 125.5 & 35.5 & 36.4 \\ \text { Process Cont ingency } & -0- & -0- & -0- \\ \text { Project Cont ingency } & 138.1 & 48.0 & 49.1 \\ \text { TOTAL PLANT COST (TPC) } & 1518.8 & 527.5 & 539.9 \\ \text { TOTAL PLANT INVESTMENT (TPI) } & 1665.4 & 543.7 & 556.5\end{array}$


Table 3-7. Conventional Plants - Capital Requirements (Continued)

Royalty Allowance

Preproduction Costs

Inventory Capital

Initial Catalysts \& Chemicals

Land Cost

TOTAL CAPITAL REQUIREMENT (TCR)

\begin{tabular}{rrr}
$-0-$ & $-0-$ & $-0-$ \\
44.2 & 19.3 & 19.7 \\
31.6 & 1.6 & 9.7 \\
$-0-$ & $-0-$ & $-0-$ \\
6.8 & 2.9 & 3.2 \\
\hline 1748.0 & 567.4 & 589.0
\end{tabular}

Table 3-8. Conventional Plants - Operating Costs

$\begin{array}{lrrr}\text { Plant Type } & \text { PC-FGD } & \text { CTCC, gas } & \text { CTCC, oil } \\ \text { OPERATION \& MAINTENANCE } & (\$ / k W-y r) & (\$ / k W-y r) & (\$ / k W-y r) \\ \text { Operating Labor } & 18.9 & 8.7 & 9.6 \\ \text { Maintenance Labor } & 14.6 & 3.9 & 3.9 \\ \text { Maintenance Material } & 21.9 & 5.8 & 5.9 \\ \text { Admin \& Support Labor } & 10.0 & 3.8 & 4.0 \\ \text { Total 0\&M (first year) } & 65.4 & 22.1 & 23.4 \\ \text { CONSUMABLE OPERATING COSTS } & (\$ / M W h) & (\$ / M W h) & (\$ / M W h) \\ \text { Water } & 0.60 & 0.49 & 0.50 \\ \text { Chemicals } & 1.05 & 0.27 & 0.27 \\ \text { Other Consumables } & -0- & -0- & -0- \\ \text { Waste Disposal } & 1.39 & -0- & -0- \\ \text { Total Consumables (first year) } & 3.03 & 0.76 & 0.77 \\ \text { FUEL COST (first year) } & 17.93 & 32.83 & 32.91\end{array}$

Table 3-9. Conventional Plants - COE Sumary

Plant Type

Total Plant Cost, $\$ / k W$

Capital Charges, $\$ / M W h$

Fixed Oper \& Maint, \$/MWh

Variable Oper \& Maint, \$/MWh

Consumables, \$/MWh

Fuel, S/MWh

Levelized COE, \$/MWh

$\begin{array}{r}\text { PC-FGD } \\ 1518.8 \\ 49.3 \\ 13.0 \\ 5.6 \\ 5.3 \\ 21.2 \\ \hline 94.4\end{array}$

CTCC, gas

527.5

16.0

4.4

1.9

1.3

60.5

84.1 
To provide the economic analysis of the direct coal fired combined cycle power plant with relevancy to current commercial technology, the costs of a conventional pulverized coal fired fossil plant were conceptually developed. For the purpose of consistency in comparisons, this cost data was developed for a nominal $220 \mathrm{MW}$ PC-FGD plant.

In determining the capital costs (process capital and general facilities), several sources were utilized. The cost estimate is based on Gilbert/ Commonwealth's (G/C) in-house reference fossil plant estimate and a recent project of a similar size. These costs include vendor quotations for major equipment supplemented by current literature, and pricing from several recently completed cost studies and estimates of $250 \mathrm{MW}$ and $350 \mathrm{MW}$ plants. In conjunction with these sources, scaling was done to allow for differences in equipment and system sizes. The site specific components, such as site development, coal handling system, ash handling and disposal, and cooling system, were estimated by adjusting the generic estimate. Based on the above approach, a direct capital cost (process capital and general facilities) of 276 million or $1,255 \$ / \mathrm{kW}$ was developed. This result was compared to other G/C in-house small PC-FGD plant data to verify that results were within the range of expected values under similar conditions.

Engineering and project contingency costs (no process contingency was required) were evaluated to yield a total plant cost value at $\$ 366$ million or $1,665 \mathrm{~s} / \mathrm{kW}$. The total plant investment factor was slightly higher for the PC-FGD plant, due to the expected longer construction period (4 years vs. 3 years). The addition of preproduction costs, inventory capital, and land cost result in a Total Capital Requirement of $\$ 384$ million or $1,748 \$ / \mathrm{kW}$.

The number of plant operators was reduced to 21 , in contrast to 23 for the CFCTCC plant. Maintenance percent values were modified, where required, but kept consistent for similar systems or equipment. Similarly, consumable costs were developed, with the PC-FGD plant values being much higher than the CFCTCC plant values for water and water treating chemicals, and waste disposal (FGD sludge) costs. However, overall chemical costs for the PC-FGD plant are much lower than the costs for the CWM CFCTCC plant due to the lack of slurry chemicals.

The cost of fuel for the PC-FGD plant was developed in a similar approach as the slurry plants and, based on the PC-FGD plant heat rate of $9960 \mathrm{Btu} / \mathrm{kWh}$, yielded a first year fuel cost of $\$ 24$ million.

The Levelized Busbar Cost of Power, as well as the levelized value of the busbar cost constituents, were determined on the same basis as were the costs for the CFCTCC plants. The COE for the PC-FGD plant was calculated to be 94.4 $\mathrm{mill} \mathrm{s} / \mathrm{kWh}$. This value, as well as the constituent values and all other capital and operating cost values, are summarized in Table 3-10. Table 3-11 summarizes the estimate basis and financial criteria used to arrive at the COE. 
Table 3-10. PC-FGD PIant COE Summary

CAPITAL INVESTMENT \& REVENUE REQUIREMENT SUMMARY

TITLE/DEFINITION

Case :

Plant Size:

Fuel (type):

Design/Construction:

TPC (Plant Cost) Year:

Capacity Factor

CAPITAL INVESTMENT

Process Capital \& Facilities

Engineering ( incl. C.M., H.O. \& Fee)

Process Contingency

Project Contingency

TOTAL PLANT COST (TPC)

TOTAL CASH EXPENDED

AFDC

TOTAL PLANT INVESTMENT (TPI)

Royalty Al lowance

Preproduction Costs

Inventory Capital

Initial Catalyst \& Chemicals

Land Cost

TOTAL CAPITAL REQUIREMENT (TCR)

OPERATING \& MAINTENANCE COSTS (First year)

Operating Labor

Maintenance Labor

Maintenance Material

Administrative \& Support Labor

TOTAL OPERATION \& MAINTENANCE (1st yr.)

FIXED 0 \& $M\left(1 s+y r_{.}\right)$

VARIABLE O \& $M(1 s+y r$.

CONSUMABLE OPERATING COSTS (Less Fuel)

Water

Chemicals

Other Consumables

Waste Disposal

TOTAL CONSUMABLES (1st yr.-fuel)

BY-PRODUCT CREDITS (First year)

FUEL COST (First Year)

LEVELIZED OPERATION \& MAINTENANCE COSTS

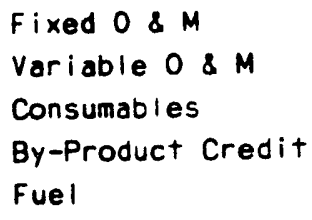

LEVELIZED BUS BAR COST OF POWER

30 Year at a Capacity Factor of:
Conventional PC Fired Power PIant with FGD

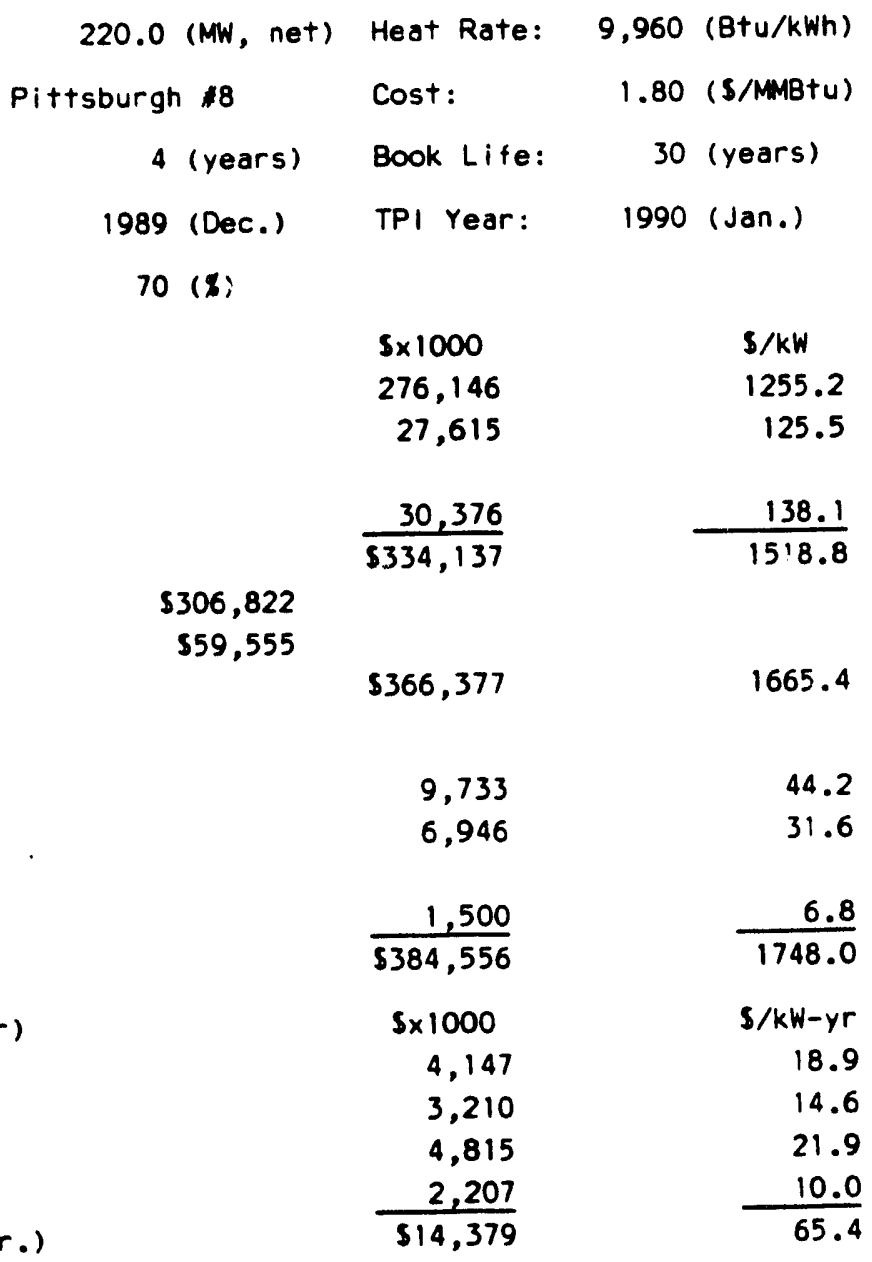

$45.75 \mathrm{~s} / \mathrm{kW}-\mathrm{yr}$

$3.20 \mathrm{mills} / \mathrm{kWh}$

$\$ \times 1000$

$\mathrm{mills} / \mathrm{kWh}$

0.60

811

1.05

1,413

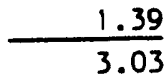

$\$ 24,186$

17.93

$79.9 \mathrm{~S} / \mathrm{kW}-\mathrm{yr}$

$5.6 \mathrm{mi} / \mathrm{ls} / \mathrm{kWh}$

$5.3 \mathrm{mills} / \mathrm{kWh}$ $\mathrm{mi} / 1 \mathrm{~s} / \mathrm{kWh}$

$21.2 \mathrm{mills} / \mathrm{kWh}$

$94.4 \mathrm{mills} / \mathrm{kWh}$ 
ESTIMATE BASIS/FINANCIAL CRITERIA FOR REVENUE REQUIREMENT CALCULATIONS

GENERAL DATA/CHARACTERISTICS

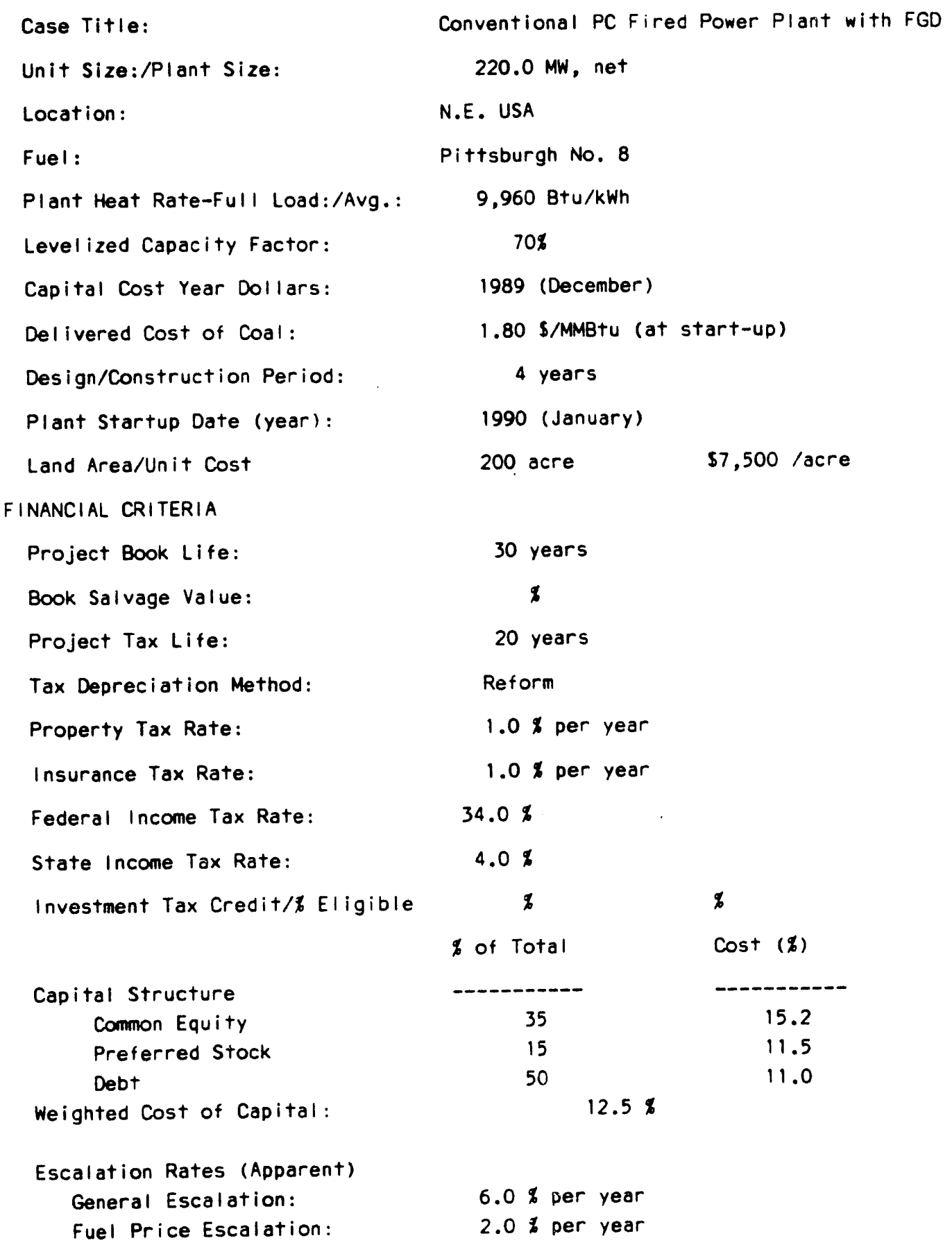


The power generating island is based on two current generation gas turbines, each equipped with its own hydrogen-cooled electric generator rated at 100,000 kVA. The gas turbine combustors are designed for dual fuel operation so that they can be scarted on natural gas or 011 . The gas turbines used in combine cycle plants are assumed to have inlet and exhaust losses of 4 inches of water ano 10 inches of water, respectively.

Overall, the gas turbine generator is approximately 70 feet long by 29 feet wide by 13 feet high. Each gas turbine exhaust is connected to a heat recovery steam generator (HRSG) which produces steam at two pressure levels (1.622 psia and 312 psia). The HRSGs are approximately 40 feet wide by 50 feet long by 40 feet high, and exhaust to individual stacks approximately 125 feet tal1. The HRSG is equipped with a duct burner that fires natural gas to heat the gâs turbine exhaust to $1200^{\circ} \mathrm{F}$.

NO control ror the gas turbine will be achieved by water injection. For this conceptual design, a water to fuel mass flow ratio of $1: 1$ was assumed to reduce $\mathrm{NO}_{\mathrm{x}}$ emission to $42 \mathrm{ppm}(\mathrm{v})$ dry at $15 \% \mathrm{O}_{2}$ for gas and $65 \mathrm{ppm}(\mathrm{v})$ at $15 \%$ $\mathrm{O}_{2}$ for oit.

Upstream of the HRSG is an exhaust bypass stack that is approximately 75 feet tal1. This stack, equipped with silencers, allows the gas turbine to operate in a simple cycle mode when the HRSG or steam cycle equipment is inoperative. This stack also allows the operator to divert some of the exhaust gas away from the HRSG during start-up to assist in bringing the steam cycle equipment on line.

The steam turbine used in the configuration is a current generation non-reheat type with $1450 \mathrm{psig} / 1000^{\circ} \mathrm{F}$ throttle condition, and a 2.5-in. HgA back pressure. The high pressure turbine element is housed in a single casing and exhausts to a separate low pressure turbine with a double flow exhaust and 26in. last stage blades. The steam turbine has two extraction ports to provide steam to a low pressure feedwater heater and the deaerator. The steam turbine is attached to a dedicated, hydrogen-cooled electric generator rated at 138,000 kVA.

Steam cycle heat rejection is through a wet, mechanical draft cooling tower. The cooling tower is designed to achieve a 2.5-in. of mercury condenser pressure for $a 75^{\circ} \mathrm{F}$ wet bulb, a $9^{\circ} \mathrm{F}$ approach, and a $19.7^{\circ} \mathrm{F}$ range. Maximum circulating water temperature is $103.7^{\circ} \mathrm{F}$ : A set of two $50 \%$ capacity pumps circulate water from the cooling tower to the condenser at a pressure of 80 feet of water.

Each gas turbine exhausts into a stack which is 75-feet tall. The stack is equipped with silencing material and is arranged so that future flue gas bypass dampers and HRSG addition can be easily accommodated for combined cycle conversion.

The capital cost, operating costs, and COE for gas-fueled and oil-fueled combined cycles are shown in Tables 3-12 and 3-13, respectively. The financial bases for these calculations are shown in Tables 3-14 and 3-15. 
Table 3-12. Gas-Fueled Combined Cycle COE Summary CAPITAL INVESTMENT \& REVENUE REQUIREMENT SUMMARY

TITLE/DEFINITION

Case :

Plant Size:

Fuel (type):

Design/Construction:

TPC (Plant Cost) Year:

Capacity Factor

CAPITAL INVESTMENT

Process Capital \& Facilities

Engineering ( incl. C.M., H.O. \& Fee)

Process Contingency

Project Contingency

TOTAL PLANT COST (TPC)

TOTAL CASH EXPENDED

AFDC

TOTAL PLANT INVESTMENT (TPI)

Royalty Allowance

Preproduction Costs

Inventory Capital

Initial Catalyst \& Chemicals

Land Cost

TOTAL CAPITAL REQUIREMENT (TCR)

OPERATING \& MAINTENANCE COSTS (First year)

Operating Labor

Maintenance Labor

Maintenance Material

Administrative \& Support Labor

TOTAL OPERATION \& MAINTENANCE (1st yr.)

FIXED $O$ \& $M$ (ist $\left.y r_{.}\right)$

VARIABLE 0 \& $M$ (1st yr.)

CONSUMABLE OPERATING COSTS (LeSS FUEI)

Water

Chemicals

Other Consumables

Waste Disposal

TOTAL CONSUMABLES (ist yr.-fuel)

BY-PRODUCT CREDITS (First year)

FUEL COST (First Year)

LEVELIZED OPERATION \& MAINTENANCE COSTS

Fixed $O \& M$

Variable $0 \& M$

Consumables

By-Product Credit

Fuel

LEVEL IZED BUSBAR COST OF POWER

30 Year at a Capacity Factor of:
Natural Gas Combined Cycle Plant

$$
261.8 \text { (MW, net) Heat Rate: }
$$

Natural Gas

Cost:

8,208 (B+u/kWh)

2 (years)

Book Life:

4.00 (S/MMBtu)

1989 (Dec.)

TPI Year:

30 (years)

1990 (Jan.)

$70(\%)$

\begin{tabular}{rr}
$\$ \times 1000$ & \multicolumn{1}{c}{$\$ / \mathrm{kW}$} \\
116,235 & 444.0 \\
9,299 & 35.5 \\
& \\
12,553 & 48.0 \\
\hline$\$ 138,088$ & 527.5
\end{tabular}

$\$ 134,179$

$\$ 8,171$

$\$ 142,351$

543.7

$$
5,043
$$

407

$\frac{750}{\$ 148,551}$

$5 \times 1000$

2,271

1,009

1,514

984

5 5,779

$\$ \times 1000$

787

435

$\$ 1,222$

$\$ 52,707$

32.83

$27.0 \mathrm{~s} / \mathrm{kW}-y \mathrm{r}$

$1.9 \mathrm{mil} / \mathrm{s} / \mathrm{kWh}$

$1.3 \mathrm{mi} / \mathrm{s} / \mathrm{kWh}$

$\mathrm{mi} \mid \mathrm{ls} / \mathrm{kWh}$

$60.5 \mathrm{mills} / \mathrm{kWh}$

$84.1 \mathrm{mi} \mid \mathrm{s} / \mathrm{kWh}$ 
Table 3-13. Oil-fueled Combined Cycle COE Sumnary

CAPITAL INVESTMENT \& REVENUE REQUIREMENT SUMMARY

TITLE/DEFINITION

Case:

Plant Size:

Fuel (type):

Design/Construction:

TPC (PIant Cost) Year:

Capacity Factor

CAPITAL INVESTMENT

Process Capital \& Facilities

Engineering ( incl. C.M., H.O. \& Fee)

Process Contingency

Project Contingency

TOTAL PLANT COST (TPC)

TOTAL CASH EXPENDED

AFDC

TOTAL PLANT INVESTMENT (TPI)

Royalty Allowance

Preproduction Costs

Inventory Capital

Initial Catalyst \& Chemicals

Land Cost

TOTAL CAPITAL REQUIREMENT (TCR)

OPERATING \& MAINTENANCE COSTS (First year)

Operating Labor

Maintenance Labor

Maintenance Material

Administrative \& Support Labor

TOTAL OPERATION \& MAINTENANCE (1st yr.)

FIXED $O \& M\left(1 s+y r_{.}\right)$

VARIABLE $O \& M\left(1 s+y r_{.}\right)$

CONSUMABLE OPERATING COSTS (LeSS FUEI)

Water

Chemicals

Other Consumables

Waste Disposal

TOTAL CONSUMABLES (ist $y r_{.}-f$ Uel $)$

BY-PRODUCT CREDITS (First year)

FUEL COST (First Year)

LEVELIZED OPERATION \& MAINTENANCE COSTS

Fixed $0 \& M$

Variable $O$ \& $M$

Consumables

By-Product Credit

Fuel

LEVEL I ZED BUSBAR COST OF POWER

30 Year at a Capacity Factor of:
Distillate Oil Combined Cycle Plant

258.4 (MW, net) Heat Rate: 8,227 (Btu/kWh)

Distillate 0il

Cost:

4.00 (S/MMBtu)

2 (years)

Book Life:

30 (years)

1989 (Dec.)

TPI Year:

1990 (Jan.)

$70(x)$

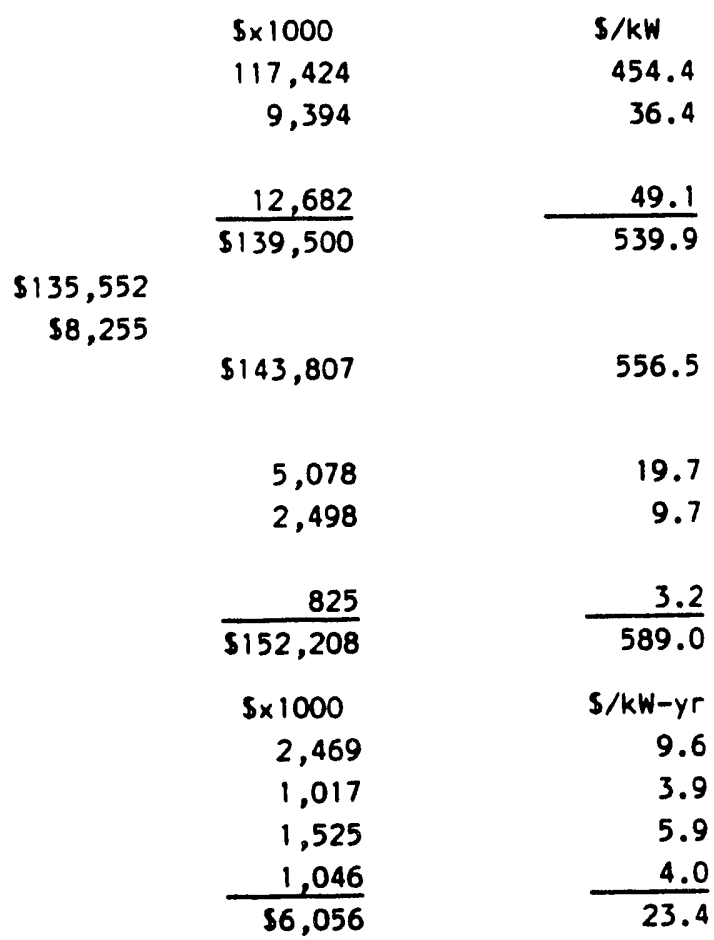

$16.41 \mathrm{~S} / \mathrm{kW}-\mathrm{yr}$

$1.15 \mathrm{mills} / \mathrm{kWh}$

$5 \times 1000$

787

435

mil/s/kwh

0.50

0.27

$\$ 1,222$

0.77

$\$ 52,143$

32.91

$28.6 \mathrm{~s} / \mathrm{kW}-\mathrm{yr}$

$2.0 \mathrm{mi} / 1 \mathrm{~s} / \mathrm{kWh}$

$1.3 \mathrm{mi} / 1 \mathrm{~s} / \mathrm{kWh}$

mills/kwh

$60.6 \mathrm{mills} / \mathrm{kWh}$

$85.2 \mathrm{mi} / \mathrm{s} / \mathrm{kWh}$ 
Table 3-14. Gas-fueled Combined Cycle Financial Basis

ESTIMATE BASIS/FINANCIAL CRITERIA fOr REVENUE REQUIREMENT CALCULATIONS

GENERAL DATA/CHARACTERISTICS

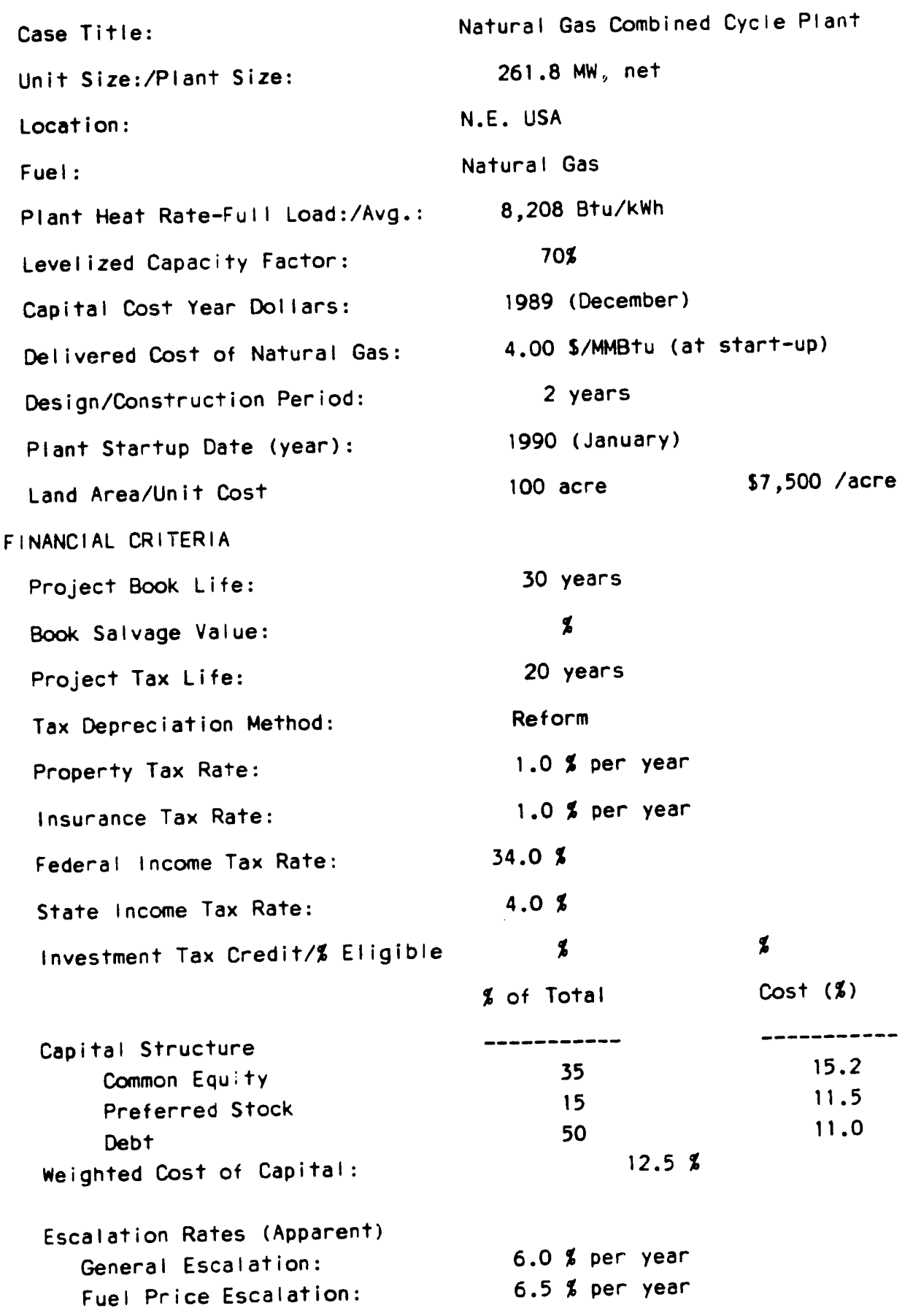


Table 3-15. Oil-Fueled Combined Cycle Financial Basis

ESTIMATE BASIS/FINANCIAL CRITERIA fOr REVENUE REQUIREMENT CALCULATIONS

GENERAL DATA/CHARACTERISTICS

\begin{tabular}{|c|c|}
\hline Case Title: & Distillate Oil Combined Cycle Plant \\
\hline Unit Size:/Plant Size: & $258.4 \mathrm{MW}$, net \\
\hline Location: & N.E. USA \\
\hline Fuel: & Distillate Oil \\
\hline Plant Heat Rate-Full Load:/Avg.: & $8,227 \mathrm{~B}+u / \mathrm{kWh}$ \\
\hline Levelized Capacity Factor: & 708 \\
\hline Capital Cost Year Dollars: & 1989 (December) \\
\hline Delivered Cost of Oil: & $4.00 \mathrm{~s} / \mathrm{MMB}+u$ (at start-up) \\
\hline Design/Construction Period: & 2 years \\
\hline Plant Startup Date (year): & 1990 (January) \\
\hline Land Area/Unit Cost & $\$ 7,500$ /acre \\
\hline FINANCIAL CRITERIA & \\
\hline Project Book Life: & 30 years \\
\hline Book Salvage Value: & $\$$ \\
\hline Project Tax Life: & 20 years \\
\hline Tax Depreciation Method: & Reform \\
\hline Property Tax Rate: & $1.0 \%$ per year \\
\hline Insurance Tax Rate: & $1.0 \&$ per year \\
\hline Federal Income Tax Rate: & $34.0 \%$ \\
\hline State Income Tax Rate: & $4.0 \%$ \\
\hline Investment Tax Credit/\$ Eligible & 8 \\
\hline & b of Total \\
\hline Capital Structure & $-\cdots-\cdots$ \\
\hline Common Equity & 15.2 \\
\hline Preferred Stock & 11.5 \\
\hline Debt & 11.0 \\
\hline Weighted Cost of Capital: & $12.5 \not$ \\
\hline Escalation Rates (Apparent) & \\
\hline General Escalation: & $6.0 \%$ per year \\
\hline Fuel Price Escalation: & $6.5 \%$ per year \\
\hline
\end{tabular}




\subsection{Cost of Electricity Calcuiations}

Cost of electricity was chosen because it considers the total plant configuration. As a comprehensive evaluator, the COE calculation entails several sets of constituent calculations which are described in this section.

The revenue requirement method is used to compile the COE. This method is generally used by electric utilities to assess the economic consequences of alternatives. The overall COE calculation is displayed in Figure 3-1. The individual calculations shown in the figure are explained in greater detail in subsequent paragraphs:

- Section 3.2.1 describes the Total ?lant Cost

- Section 3.2.2 converts the cost into Total Plant Investment

- Section 3.2.3 explains Total Capital Requirements

- Section 3.2.4 discusses Operation and Maintenance Costs

- Section 3.2.5 explains the use of levelizing factors

- Section 3.2.6 lists the COE of the first plant

- Section 3.2.7 tabulates the COE of a mature plant

\subsubsection{Total Plant Cost}

The installed cost of all equipment and facilities of the power plant, including the cost of services related to installation, is the total plant cost (TPC). When the TPC is divided by the plant net power output, the resulting figure, in $\$ / \mathrm{kW}$, is a widely used evaluator of power systems. The total plant costs of the Reference System Plants are tabulated in Table 3-16 and Table 3-17.

The cost of each item in the power plant is the sum of four constituent costs:

- Process capital and general facilities

- Engineering and home office overhead charge

- Process contingency

- Project contingency

\section{Process Capital and General Facilities}

Process capital is the total constructed cost of all on-site processing and generating systems. Process capital includes equipment, direct labor, and indirect labor. General facilities, reported as structures and site work, is the constructed cost of all roads, yard facilities, office buildings, shops, laboratories, and storage systems for fuel, chemicals, and by-products.

\section{Engineering and Home Office Overhead Charge}

The engineering and home office overhead charge, which includes a cost allowance for construction management, is presented as a fraction of process capital and general facilities. A representative composite fraction of 10 percent was applied to each item in the cost estimate. 


\section{Process Contingency}

The probability of functional success of each component is reflected in its process contingency. Continuing development of the newer components tends to increase their costs as problems are discovered and solved. The process contingency, expressed as a percent of the process capital cost, quantifies this development uncertainty in equipment design and performance in the form of a cost, process contingency factors generally follow the guidelines published by EPRI, as listed in Table 3-18.

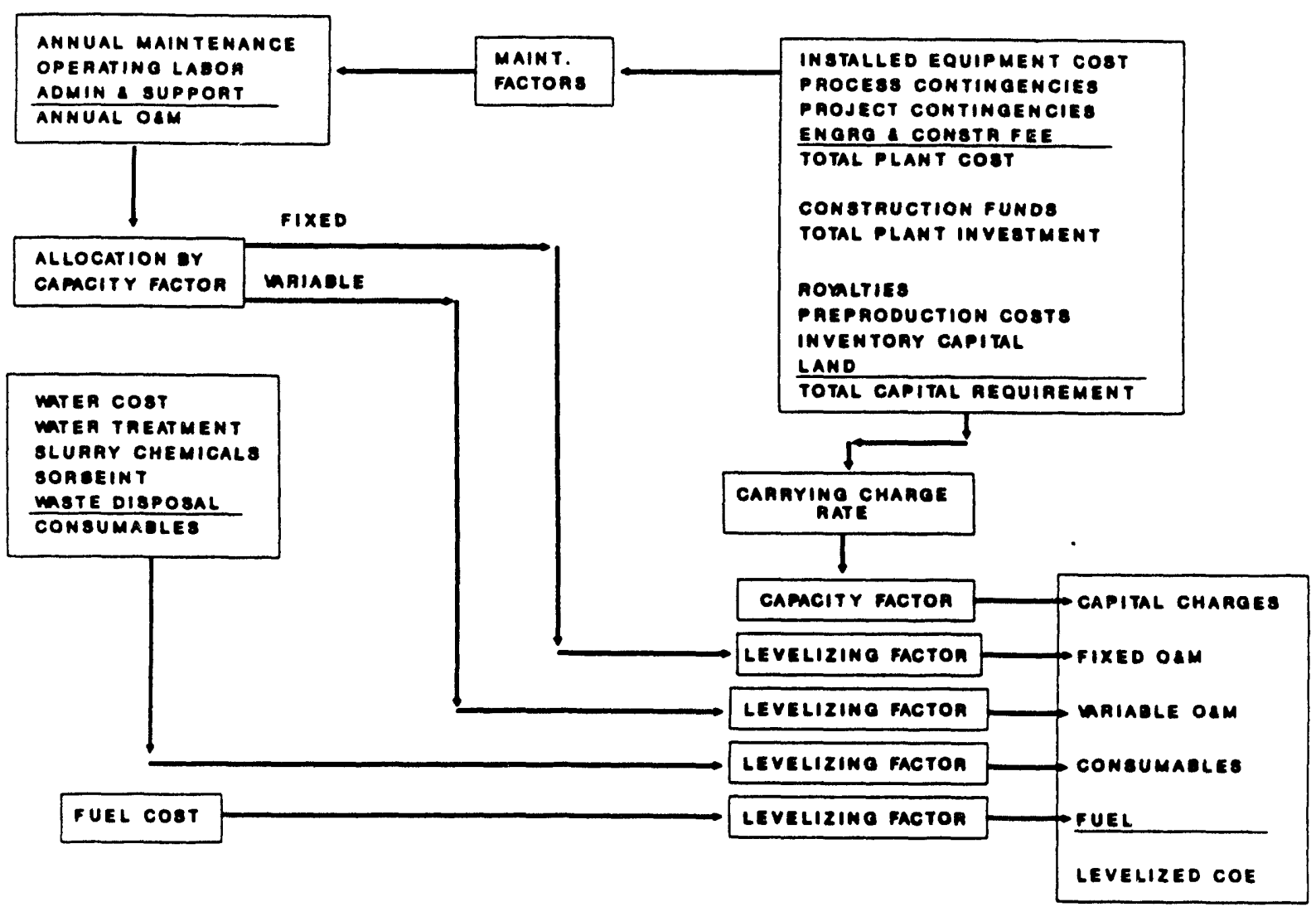

Figure 3-1. COE Calculation Model 
Table 3-16. PC CFCTCC Plant Costs (Thousand 1989 Dollars)

\begin{tabular}{|c|c|c|c|c|c|}
\hline ANT SECTION & GEN FAC: & PROJECT & PROCESS & MGT FEE & COST \\
\hline $\begin{array}{l}\text { Coal Processing } \\
\text { Slagging Combstr } \\
\text { Compressor Inlet } \\
\text { Inlet Filter } \\
\text { Main Compressor } \\
\text { LP Expander } \\
\text { Generator } \\
\text { Steam Power Plant } \\
\text { Stm Cyc Clg Twr } \\
\text { Heat Exchangers } \\
\text { Instr. + Controls } \\
\text { Access. Electric } \\
\text { Other BOP Equip. } \\
\text { Structures } \\
\text { Site Work }\end{array}$ & $\begin{array}{c}29604 . \\
19476 . \\
2124 . \\
536 . \\
8198 . \\
17028 . \\
10020 . \\
33956 . \\
4680 . \\
12849 . \\
8460 . \\
18504 . \\
14097 . \\
19939 . \\
8128 .\end{array}$ & $\begin{array}{r}2960 . \\
1948 . \\
212 . \\
54 . \\
820 . \\
1703 . \\
1002 . \\
3396 . \\
468 . \\
1285 . \\
846 . \\
1850 . \\
1410 . \\
1994 . \\
813 .\end{array}$ & $\begin{array}{r}2960 . \\
3895 . \\
0 . \\
0 . \\
0 . \\
851 . \\
0 . \\
0 . \\
0 . \\
64 . \\
0 . \\
0 . \\
0 . \\
0 . \\
0 .\end{array}$ & $\begin{array}{r}3256 . \\
2142 . \\
234 . \\
59 . \\
902 . \\
1873 . \\
1102 . \\
3735 . \\
515 . \\
1413 . \\
931 . \\
2035 . \\
1551 . \\
2193 . \\
894 .\end{array}$ & $\begin{array}{r}38781 . \\
27461 . \\
2570 . \\
649 . \\
9920 . \\
21455 . \\
12124 . \\
41087 . \\
5662 . \\
15612 . \\
10237 . \\
22390 . \\
17057 . \\
24126 . \\
9835 .\end{array}$ \\
\hline rotal (\$k) & 207599. & 20760 . & 7771. & 22836 . & 966. \\
\hline Total $(\$ / \mathrm{kW})$ & 935.8 & 93.6 & 35.0 & 102.9 & 1167.3 \\
\hline
\end{tabular}

Table 3-17. CMM CFCTCC Plant Costs (Thousand 1989 Dollars)

\begin{tabular}{|c|c|c|c|c|c|}
\hline PLANT SECTION & $\begin{array}{l}\text { PROC. CAP. } \\
\& \text { GEN FAC. }\end{array}$ & $\begin{array}{r}\text { CONTIN } \\
\text { PROJECT } \\
\end{array}$ & $\begin{array}{l}\text { ENCIES } \\
\text { PROCESS }\end{array}$ & $\begin{array}{l}\text { ENGRG } \\
+ \text { +CONSTR } \\
\text { MGT FEE }\end{array}$ & $\begin{array}{l}\text { TOTAL } \\
\text { PLANT } \\
\text { COST }\end{array}$ \\
\hline $\begin{array}{l}\text { CWM Equipment } \\
\text { Slagging Combstr } \\
\text { Compressor Inlet } \\
\text { Inlet Filter } \\
\text { Main Compressor } \\
\text { LP Expander } \\
\text { Generator } \\
\text { Steam Power Plant } \\
\text { Stm Cyc Clg Twr } \\
\text { Heat Exchangers } \\
\text { Inst. + Controls } \\
\text { Access. Electric } \\
\text { Other BOP Equip. } \\
\text { Structures } \\
\text { Site Work }\end{array}$ & $\begin{array}{r}22118 . \\
21644 . \\
2124 . \\
536 . \\
8197 . \\
17636 . \\
10506 . \\
34678 . \\
4753 . \\
12716 . \\
8857 . \\
18504 . \\
14097 . \\
19939 . \\
8128 .\end{array}$ & $\begin{array}{l}2212 . \\
2164 . \\
212 . \\
54 . \\
820 . \\
1764 . \\
1051 . \\
3468 . \\
475 . \\
1272 . \\
886 . \\
1850 . \\
1410 . \\
1994 . \\
813 .\end{array}$ & $\begin{array}{r}2212 . \\
4329 . \\
0 . \\
0 . \\
0 . \\
882 . \\
0 . \\
0 . \\
0 . \\
64 . \\
0 . \\
0 . \\
0 . \\
0 . \\
0 .\end{array}$ & $\begin{array}{c}2433 . \\
2381 . \\
234 . \\
59 . \\
902 . \\
1940 . \\
1156 . \\
3815 . \\
523 . \\
1399 . \\
974 . \\
2035 . \\
1551 . \\
2193 . \\
894 .\end{array}$ & $\begin{array}{r}28974 . \\
30518 . \\
2570 . \\
649 . \\
9918 . \\
22221 . \\
12712 . \\
41961 . \\
5751 . \\
15450 . \\
10718 . \\
22390 . \\
17057 . \\
24126 . \\
9835 .\end{array}$ \\
\hline Total & 2044 & & & 22488 . & 32. \\
\hline otal $(\$ / \mathrm{kW}$ & 883.8 & 88.4 & 32.4 & 97.2 & 1101.8 \\
\hline
\end{tabular}


Table 3-18. Development Categories

State of Technology Development

Process Contingency

The process is used commercially

A full-sized module has been operated

Small pilot plant data is available

Concept with bench-scale data available

New concept with limited data

$\begin{aligned} & 0-5 \% \\ & 5=10 \% \\ & 10=15 \% \\ & 15=25 \% \\ & 25 \% \text { and higher }\end{aligned}$

The process contingency factors for the equipment items in the power plant are listed in Table 3-19. Process contingencies for advanced components are based on the judgements of the technical experts working on this study.

Table 3-19. Process Contingency Factors

Equipment Process Contingency Factor

Coal Processing

CWM Plant Equipment

Combustor

$10 \%$

$10 \%$

Main Compressor

Expander

Generator (Expander)

Steam Power Plant

Cooling Tower (Circ. Matl)

$40 \%$

Heat Exchangers

Instrumentation and Controls

$0 \%$

$5 \%$

$0 \%$

$0 \%$

Accessory Electric

Other BOP Equipment

Structures

Site Work

$0 \%$

$0 \%$

$0 \%$

$0 \%$

$0 \%$

$0 \%$

$0 \%$

\section{Project Contingency}

Consistent with conventional power plant practice, a general project contingency was added to the total plant cost to cover the cost of any additional equipment that could result from a detailed design. The project contingency is intended to cover uncertainties in the cost estimate itself, whereas the process contingency covers uncertainties in the technical performance of the equipment. A nominal value of 10 percent project contingency was applied to each item in the cost estimate.

The total plant cost is estimated on the basis of instantaneous construction, and does not include any consideration of financing or construction time. 


\subsubsection{Total Plant Investment}

The Total Plant Investment (TPI) at date of start-up includes consideration for escalation of construction costs and allowance for funds used during construction (AFDC, formerly called interest during construction) over the construction period. TPI is computed from the total plant cost where the TPC is expressed on an "overnight" or instantaneous construction basis. The calculation method for TPI is taken from the EPRI Technical Assessment Guide (TAG):

$$
\text { TPI }=\text { TPC } \times \text { AFtPi }
$$

where:

$$
\begin{aligned}
& \text { AFtpi }=\left(Z^{N-1}\right) /(Z-1)^{N} \\
& Z=(1+i) /(1+\text { ea }) \\
& i=\text { Weighted cost of capital } \\
& \text { ea }=\text { Apparent escalation rate for equipment } \\
& N=\text { Construction period, years }
\end{aligned}
$$

The equation is based on a uniform expenditure rate over the construction period, with all expenditures taking place at the end of each year. The construction period for this purpose was established as three years. The apparent escalation rate for this calculation was 6 percent per year, while the discount rate was 12.5 percent.

\subsubsection{Total Capital Requirements}

The Total Capital Requirement (TCR) value includes all capital necessary to complete the entire project. The TCR is the sum of the TPI, prepaid royalties, preproduction (or start-up) costs, inventory capital, initial chemical and catalyst charge, and land cost.

Prepaid Royalties: The paid-up royalties allowance was estimated to be 0.5 percent of the associated process capital. Royalties were charged for cleanup devices, the compressor, the combustor, the expander and the slurry plant.

Preproduction Costs: The preproduction costs are intended to cover operator training, equipment checkout, major changes in plant equipment, extra maintenance, and inefficient use of fuel and other materials during plant start-up. The preproduction costs are estimated as follows:

- One month of fixed operating costs. Fixed operating costs are operating and maintenance labor, administrative and support labor, and maintenance materials.

- One month of variable operating costs at full capacity excluding fuel. These variable operating costs include chemicals, water, and other consumables and waste disposal charges.

- 25 percent of full capacity fuel cost for one month. This charge covers inefficient operation that occurs during the start-up period. 
- 2 percent of total plant investment (TPI). This charge covers expected changes and modifications of equipment that will be needed to bring the plant up to full capacity.

Inventory Capital: The inventory capital is the value of inventories of fuel and other consumables. The inventory is estimated to be a 60-day supply of fuel and other consumables (excluding water) based on full capacity operation.

Initial Catalyst and Chemicals: The initial catalyst and chemical charge is the initial cost of any catalysts or chemicals that are contained in the process equipment (but not in storage, which is covered in inventory capital). No value is shown because charges are included in the component material capital cost.

Land Cost: The required land area was determined on the basis of similar plot plans to be 90 acres. The land cost was $\$ 7,800$ per acre.

The TCR of a plant is converted into an operating cost by expressing it as the levelized carrying charge, which is the revenue obligation needed to support the investment in the plant. The carrying charge is the sum of return of debt, return on equity, federal and state income tax liability, book depreciation, property taxes, and insurance. The values of these components are listed with other plant financial assumptions in Section 3.1.3, and levelization is discussed in Section 3.2.5.

The total capital requirements and levelized carrying charge for both Reference power plants are summarized in Table 3-20.

Table 3-20. First CFCTCC Plant Capital Requirements

Plant Type

CAPITAL INVESTMENT

Process Capital \& Facilities

Engrg \& H.O. Fee

Process Contingency

Project Contingency

TOTAL PLANT COST (TPC)

TOTAL PLANT INVESTMENT (TPI)

Royalty Allowance

Preproduction Costs

Inventory Capital

Initial Catalysts \& Chemicals

Land Cost

TOTAL CAPITAL REQUIREMENT (TCR)
Dry PC

( $\$ / \mathrm{kW})$

935.8

102.9

35.0

93.6
1167.3

1240.4

2.0

35.7

29.7

$-0-$

3.3
1311.0
CWM

(\$/kW)

883.8

97.2

32.4

88.4

1101.8

1170.7

1.8

37.6

37.4

$-0-$

$\frac{3.2}{1250.6}$ 


\subsection{Operation and Maintenance Costs}

The operating and related maintenance costs are combined under the following headings: Operating Labor, Maintenance Labor, Maintenance Material, and Administrative \& Support Labor. Once determined, the sum of these values is re-apportioned into fixed (independent of plant power generation) and variable (directly proportional to the amount of power generated) components.

\subsubsection{Operating Costs}

The operating costs are estimated on a first year basis and given in December 1989 dollars. The "first year" costs assume normal operation and do not include the initial start-1,p costs, which are computed separately. The costs are subsequently presented on a 30-year levelized basis.

The cost of operating labor was estimated on the basis of the number of operating jobs (OJ) that are required to operate the plant. The operating labor charges (OLC) were then computed using the average labor rate as follows:

$O L C=\frac{(0 \mathrm{~J}) \times \text { (Labor Rate } \times \text { Labor Burden) } \times(8766 \mathrm{hr} / \mathrm{yr})}{\text { (net capacity of plant at ful1 load in } \mathrm{KW})}$

Table 3-21, CFCTCC Plant Operating Labor Requirements, indicates the number of operating jobs, the operating labor rate, and the operating labor burden that were used to determine the first year operating labor cost value. The operating labor requirements were determined on the basis of data provided by the United Coal Company for the slurry plant, supplemented by $G / C$ data for combined cycle plants and subsequently adjusted for expected other labor requirements to arrive at total plant operating requirements.

Table 3-21. CFCTCC Plant Operating Labor Requirements

Operating Labor Rate (base): Operating Labor Burden:

Labor Overhead Charge Rate:

Operating Labor Requirements (0J) per shift:

\section{Category}

Skilled Operator

Operator

Foreman

Lab Techs, etc.

TOTAL (OJs)
1 Unit/Mod.

3.0

16.0

2.0

$\frac{2.0}{23.0}$
$\$ 16.10 / \mathrm{hr}$

35 percent of base

30 percent of labor

\section{Total Plant}

3.0

16.0

2.0

$-\frac{2.0}{23.0}$ 


\subsubsection{Maintenance Costs}

Since the development of the maintenance labor and maintenance material costs are interrelated, these two costs are discussed together. Annual maintenance costs, especially for new technologies, are of ten estimated as a percentage of the installed capital cost of the facilities. The percentage varies widely depending on the nature of the processing conditions and the type of design.

Maintenance factors for the equipment in the power plant are listed in Table 3-22. A typical piece of equipment has an annual maintenance factor of 1.5 percent. Items that are expected to need more maintenance have higher maintenance factors, and items needing less maintenance have lower factors.

Table 3-22. CFCTCC Maintenance Factors

Equipment

Coal Processing

CWM Plant Equipment

Slagging Combustor

Main Compressor

Expander

Generator (Expander)

Steam Power Plant

Cooling Tower (Circ. Mat 1)

Heat Exchangers

Instrumentation and Controls

Accessory Electric

Other BOP Equipment

Structures

Site Work
Factor

$3.0 \%$

$3.0 \%$

$3.0 \%$

$3.0 \%$

$3.0 \%$

$1.5 \%$

$1.5 \%$

$1.5 \%$

$2.0 \%$

$1.5 \%$

$1.5 \%$

$2.0 \%$

$0.5 \%$

$1.5 \%$

Since the maintenance costs should be separately expressed as maintenance labor and maintenance materials, a maintenance labor/materials ratio of $40 / 60$ was used for this breakdown. This ratio is consistent with EPRI guidelines.

The administrative and support labor cost is an 08M overhead charge for administrative and support labor. This charge taken as 30 percent of the operating and maintenance labor. General and administrative expenses are not included.

\section{3:3.3 Fixed and Variable Components}

The total of operating and maintenance costs are divided into fixed and variable 0\&M costs. The fixed costs are essentially independent of capacity factor, and are generally expressed as $\$ / k W-y r$. The variable costs are directiy proportional to the amount of power produced, and are generally expressed as $\$ / M W h$.

Based on EPRI guideline and utility experience, base-loaded plants tend to have a relatively high fixed component of the operating cost, whereas peaking and intermediate plants have a relatively high variable component. It was 
therefore assumed that the fixed portion of the operating cost is equal to the expected nominal capacity factor for the plant. The balance of the cost is then assumed to be variable. An example of the calculation is shown below.

Fixed 0\&M = Capacity Factor (CF) $\times$ Total 0\&M (\$/kW-yr)

Variable $0 \& M=\frac{[(1-C F) \times \text { Tota } 10 \& M \times 1,000 \mathrm{mil} 1 \mathrm{~s} / \$ 1}{(C F \times 8,760 \mathrm{hrs} / \mathrm{yr})}$

\subsection{Fuel and Consumables}

The fuel, feedstock, and disposal costs reported in this section pertain to the CWM-fired combined cycle power plant. In terms of a strict EPRI-TAG terminology these items are referred to as consumable operating costs, byproduct credits, and fuel costs.

Consumable operating costs are developed on a first year bas is and subsequently levelized over the 30-year life of the plant. The quantities and unit costs that were used to develop the corresponding cost values are included in Table 3-23.

The water component is the acquisition charge for water required for the plant steam cycle and slurry plant. The water treatment chemicals consist of the $\mathrm{H}_{2} \mathrm{SO}_{4}$ and caustic required to treat the associated water quantity.

\section{Table 3-23. CFCTCC Fuel and Consumables}

Turbine Fuel

Coal - Pittsburgh No. 8

Water

Water Treatment

Dispersant

Stabilizer

pH Modifier

Sorbent - Limestone

Nitrogen

Solids Disposal
$60 / 40$ CWM

Dry Coal

Cost

$(\$ / k 1 b)$

0.08

120.00

240.0

$2,750.00$

167.43

8.57

48.43

4.60
Flow

$\frac{(1 \mathrm{~b} / \mathrm{h})}{152,289}$

479,309

276

2,014

426

1,534

30,025

36,193
Flow

$(1 \mathrm{~b} / \mathrm{h})$

$1 \frac{1}{39,702}$

369,830

213

0

0

27,543

17,463

33,202

Waste disposal is the cost allowance for off-site disposal of plant solid wastes. The sludge is the dry-weight equivalent of the beneficiation plant tailings. The unit cost for disposal was based on the EPRI recommended value. The dry solids quantity is the composite of captured ash and spent sorbent. Again, the unit cost for disposal was based on the EPRI recommended value.

For the coal, as well as for all feedstock and disposal costs, the quantities represent the 100-percent capacity requirement, while all values in the COE tables are adjusted for the designated 70-percent power plant capacity factor. 
The estimated operating costs for the first year of commercial operation are summarized in Table 3-24. These costs provide data that is used to calculate the levelized busbar COE.

Table 3-24. CFCTCC Reference System Operating Costs

$\begin{array}{lrr}\text { Plant Type } & \text { CWM } & \text { Dry PC } \\ \text { OPERATION \& MAINTENANCE } & (\$ / k W-y r) & (\$ / k W-y r) \\ \text { Operating Labor } & 16.43 & 17.14 \\ \text { Maintenance Labor } & 8.05 & 8.61 \\ \text { Maintenance Material } & 12.08 & 12.92 \\ \text { Admin \& Support Labor } & 7.35 & 7.72 \\ \text { Total O\&M (first year) } & \frac{43.92}{46.39} \\ \text { CONSUMABLE OPERATING COSTS } & (\$ / M W h) & (\$ / M W h) \\ \text { Water } & 0.17 & 0.14 \\ \text { Water Treatment } & 0.14 & 0.12 \\ \text { CWM Dispersant } & 2.09 & -0- \\ \text { CWM Stabilizer } & 5.07 & -0- \\ \text { pH Modifier } & 1.11 & -0- \\ \text { Sorbent } & 1.11 & 1.06 \\ \text { Nitrogen } & -0 . & 3.81 \\ \text { Waste Disposal } & 0.72 & 0.69 \\ \text { Total Consumables (first year) } & 10.42 & 5.82 \\ \text { FUEL COST (first year) } & & 15.36\end{array}$

Inflation will tend to increase the operating costs (in current dollars) over the life of the plant. In order to avoid the complication of varying each of the fixed and variable operation costs from year to year, a single "levelized" value is used.

The general 30-year levelizing factor, based on a 6-percent annual escalation and an 12.5-percent cost of capita1, is 1.75. This general factor is used for all levelizing calculations except for fuel. The 30-year levelizing factor for fuel, based on 2.0-percent annual escalation and an 12.5-percent cost of capital is 1.18 .

\subsection{Cost of Electricity Estimate}

The coal-pile-to-busbar cost of electricity is the conventional figure of merit used by utilities to compare power generation alternatives. The COE includes consideration of total capital requirements, represented by the levelized carrying charge (sometimes referred to as the fixed charge), levelized fixed and variable operation and maintenance costs, levelized consumable operating costs, and levelized fuel costs. The 30-year levelized COE for the first plant is summarized in Table 3-25. 
Table 3-25. First CFCTCC Plant COE Summary

Plant Type

Total Plant Cost, $\$ / \mathrm{kW}$

Capital Charges, $\$ / M W h$

Fixed Oper \& Maint, \$/MWh

Variable Oper \& Maint, \$/MWh

Consumables, $\$ / M W h$

Fue 1, \$/MWH

Levelized COE, $\$ / M W h$
CWM

1101.8

35.28

8.76

3.75

18.21

19.03

85.04
Dry PC

1167.3

36.99

9.25

3.97

10.17

18.20

\subsection{COE of a Mature Plant}

By the time the fifth plant is built, it is assumed that design improvements to the relatively new components would reduce their cost by an amount equal to the process contingency in the first plant. Consequently, the fifth plant would have a lower capital cost than the first plant. The "Mature Plant" costs reflect this reduced capital cost, and provide a fair comparison to the cost of mature pulverized coal plant. The COE of the mature plant is itemized in Table 3-26.

Table 3-26. Mature CFCTCC Plant COE Summary

Plant Type

Total Plant Cost, $\$ / \mathrm{kW}$

Capital Charges, $\$ / M W h$

Fixed Oper \& Maint, \$/MWh

Variable Oper \& Maint, \$/MWh

Consumables, \$/MWh

Fue 1, \$/MWh

Levelized COE, \$/MWh

COE Margin (ref: $\$ 94.4 / \mathrm{MWh}$ )
CWM Dry PC

$1,069.4$

34.29

8.76

3.75

18.21

19.03

84.05

$11.0 \% \quad 17.9 \%$ 


\section{SLAGGING COMBUSTOR DESCRIPTION}

In slagging combustion systems, coal is burned at a temperature high enough so that coal ash melts and turns to liquid. This liquid, which flows down the combustor walls, is collected and extracted from the combustor. Therefore, there are few solid ash particles to pass out of the chamber with the hot gases and damage the turbine. In addition, the sulfur found in most coals can also be removed at this point. Calcium compounds are introduced into the chamber where they combine with the sulfur. The resulting sorbent-captured sulfur melts and joins the slag. Also, because a slagging combustor operates fuel-rich in the primary zone and lean-burn in the secondary zone, it will suppress $\mathrm{NO}_{x}$ formation.

For slagging to occur, temperatures throughout the combustion chamber, and particularly at the walls, must not fall below approximately $2600^{\circ} \mathrm{F}$, depending upon the type of coal. These temperatures are achieved by employing a proper air/fuel ratio, refractory walls, and adequate residence time for the reacting coal/air mixture. Refractory walls are used in the subscale combustor to reduce heat loss and promote slagging, during the relatively short duration development tests.

\subsection{Slagging Combustor Concept}

Slagging temperatures are attained in the first stage, where the primary combustion takes place. Larger ash and slag particles are inertially separated from the gas in a toroidal-vortex flow pattern. The fuel-rich conditions in this stage inhibit the conversion of fuel-bound nitrogen into NO. A sorbent, such as limestone, is injected into the combustor at the downstream end of the first stage where conditions are right to capture sulfur.

The second stage is an efficient impact separator that is closely coupled to the first stage. This stage collects the finer particles of slag, ash, and sorbent that are carried over from the first stage. Slag separation in the second stage takes place in three phases: the transport of molten particles from the gas stream to the wall; the flow of slag along the wall to the slag tap due to gravity; and the flow of the slag through the slag tap. Molten slag droplets separate from the gas stream by centrifugal force. The efficiency of separation depends on the velocity and the radius of turning. The thickness of the slag layer and its movement under the influence of gravitational, and gas-flow shear forces are influenced more by gas temperature and wall cooling than they are by combustor size. The slag can be prevented from freezing in the slag tap by letting a small flow of gases escape through the center of the slag tap.

Though the impact separator is very effective at removing ash/slag particles from the products of fuel-rich combustion, further particulate cleanup is required in order to meet both the turbine requirements and the NSPS requirements. In the current combustor configuration, a slagging cyclone separator has been incorporated into the fuel-rich zone of the combustor to further reduce particulate emissions. This is a novel application for cyclone separators: a literature search was performed and no evidence was found of any operating experience with a slagging cyclone separator (i.e., a cyclone separator operating at such a high temperature that the particulate matter to 
be separated is molten and the separated slag forms a flowing layer on the walls of the cyclone). It was postulated that the relatively high gas temperature in the cyclone may enable a very high cyclone collection efficiency to be attained. Re-entrainment and turbulence effects are important considerations in cyclone performance and such effects are difficult to predict. At the high temperature in the combustor second stage, the ash particles to be separated are molten and sticky. Operation with liquid ash alleviates potential problems due to re-entrainment of separated slag and allows the use of higher than normal tangential inlet velocities, thereby generating high inertial separation forces and improved collection performance.

Combustion is completed in the fuel-lean third stage, where rapid quenching with secondary air reduces the gas temperature below the temperature at which thermal $\mathrm{NO}_{\mathrm{x}}$ can form. The design of the third stage is based on conventional gas turbine combustor designi practice. The combustor uses a rich-lean approach with quick quench to control nitrogen oxides. Thermal $\mathrm{NO}_{\mathrm{x}}$ kinetics require quenching from rich to lean in a few milliseconds. This time requirement determines the number, geometry, placement, and orientation of the secondary air jets.

Integrated with the turbine, the external combustion assembly physically replaces a normal combustor. As a preliminary estimate, the external combustion assembly comprises two slagging combustor modules which are connected to the reference utility-sized combustion turbine.

\subsection{Particulate Control}

Particles and slag are removed in both the first stage and the separator stage. The toroidal-vortex flow field in the first stage separates ash particles by centrifugal collection. The separated ash particles combine with the liquid slag flowing down the combustor wall. The combustor dome design and injection arrangement result in a small toroidal-vortex radius that permits efficient separation without excessive pressure drop.

The inertial-impact separator stage collects the finer particles carried over from the first stage. Gases from the first stage are accelerated through a single nozzle and impinge on a plate. This design can efficiently remove particles of 5 microns and larger without excessive pressure drop. An acceptatle pressure drop is needed to maintain the high efficiency of the power system.

\subsection{Sulfur Control}

Sulfur is captured by injecting dolomite or limestone into the fuel-rich first stage. Under normal combustor conditions, $\mathrm{CaO}$ in the sorbent reacts with $\mathrm{SO}_{2}$ in the gas to form $\mathrm{CaSO}_{3}+\mathrm{CaSO}_{4}$, which can be removed along with the slag. Formation of CaS by reactions between calcium (inherent in the coal ash or impregnated with the coal) and pyritic sulfur in the coal ash have also been reported. This supplemental reaction would enhance the overall sulfur capture.

Results of leaching and activity tests on sulfated dolomite (CaS) have shown that it is environmentally unacceptable for disposal. Several processes are available to convert it to environmentally acceptable forms for disposal. One 
desirable process is the dry oxidation of $\mathrm{CaS}_{\text {to }} \mathrm{CaSO}_{4}$. Oxidizing the CaS in a fluidized-bed reactor at a proper temperature in excess air ( 32 moles of air per mole of $\mathrm{CaS}$ ) prevents competing reactions that form $\mathrm{SO}_{2}$ and $\mathrm{CaO}$. It is important to remove CaS from the combustor before final oxidation in the third stage. At the fuel-lean condition, sulfur is partially or completely released, and its capture presents a formidable problem.

\subsection{Nitrogen Oxide Control}

The slagging combustor concept can control $\mathrm{NO}_{\mathrm{x}}$ levels to far below those currently required by NSPS. The intense and rapid mixing of the reactants in the first stage promotes rapid volatilization of the coal and homogeneous combustion. The first stage is expected to operate with a fuel/air equivalence ratio between 1.2 and 1.4 . Under these fuel-rich conditions, fuel-bound nitrogen is converted to $\mathrm{N}_{2}$ instead of $\mathrm{NO}_{x} \cdot$ Conditions in the first and second stages also minimize the carryover of fuel-bound nitrogen to the third stage. Additional air is added to this fuel-lean stage in such a manner that the gas is rapidly quenched to below the temperature at which thermal $\mathrm{NO}_{x}$ can form.

\subsection{Alkali Control}

The relatively volatile alkali compounds can cause corrosion and deposition in the expander. They can volatilize during combustion and subsequently condense at the cooler gas turbine operating temperature to form molten alkali sulfates, which are highly corrosive. In addition, condensed alkalies can provide a sticky surface on which ash particles accumulate. This deposition buildup on the blading results in performance degradation of the gas turbine.

Alkalies (sodium and potassium) can be controlled by controlling the thermochemistry of coal ash and by operating at conditions that inhibit the volatilization of alkalies during combustion. Because most of the coal is burned in a very short time the volatilization of alkalies is limited by reaction kinetics. Further, silicates in the fused ash are relatively stable at combustion temperatures, and they can serve as getters for controlling alkalies. 


\section{ECONOMIC SENSITIVITY STUDIES}

Sensitivity studies were performed using the computer model to assess the influence of certain parameters on the COE margin of the CWM-fueled plant. Table 5-1 lists the parameters that were evaluated, along with the relative sensitivity of COE margin to each parameter.

Parameter

Combustor Outlet

Temperature, ${ }^{\circ} \mathrm{F}$

Slurry Chemical

Expense, \$M

Sulfur Capture:

Limestone Ca/S [1]

Limestone $\mathrm{Ca} / \mathrm{S}[2]$

Taconite $\mathrm{Fe} / \mathrm{S}[2]$

Combustor Capital

Cost, \$M

Reblading Interval: over 5,000 hours under 5,000 hours

Combustor Pressure Drop, $\%$

Combustor Heat Rejection, $\%$

Table 5-1. COE Sensitivities Summary

\begin{tabular}{|c|c|c|c|c|}
\hline $\begin{array}{c}\text { Reference } \\
\text { Plant } \\
\text { Value } \\
\end{array}$ & $\begin{array}{c}\text { Extreme } \\
\text { Value } \\
\end{array}$ & 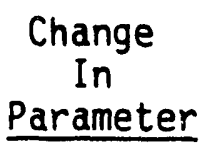 & $\begin{array}{c}\text { Possible } \\
\text { COE } \\
\text { Margin } \\
\end{array}$ & $\begin{array}{l}\text { Change } \\
\text { In COE } \\
\text { Margin } \\
\end{array}$ \\
\hline 1850 & 2150 & $16 \%$ & $19.9 \%$ & $82 \%$ \\
\hline 11.7 & 10.5 & $-10 \%$ & $12.5 \%$ & $14 \%$ \\
\hline $\begin{array}{r}2.00 \\
2.00 \\
\mathrm{n} / \mathrm{a}\end{array}$ & $\begin{array}{r}8.00 \\
6.00 \\
10.00\end{array}$ & $\begin{array}{r}300 \% \\
200 \% \\
n / a\end{array}$ & $\begin{array}{r}-3.0 \% \\
-11.8 \% \\
-53.4 \%\end{array}$ & $\begin{array}{l}-127 \% \\
-207 \% \\
-587 \%\end{array}$ \\
\hline 26.2 & 39.3 & $50 \%$ & $9.0 \%$ & $-18 \%$ \\
\hline $\begin{array}{l}25,000 \\
25,000\end{array}$ & $\begin{array}{r}40,000 \\
1,000\end{array}$ & $\begin{array}{r}60 \% \\
-96 \%\end{array}$ & $\begin{array}{r}11.2 \% \\
-34.6 \%\end{array}$ & $\begin{array}{r}2 \% \\
-416 \%\end{array}$ \\
\hline $7 \%$ & $9 \%$ & $+29 \%$ & $10.2 \%$ & $-7 \%$ \\
\hline $8 \%$ & $10 \%$ & $+25 \%$ & $10.8 \%$ & $-1 \%$ \\
\hline
\end{tabular}

11) Assuming 90\% sulfur capture without FGD

[2] Assuming FGD required

The effects of these parameters are discussed in subsequent paragraphs.

This section also describes the effect of changing natural gas prices on the COE margin of a combined cycle fueled by coal, compared to a combined cycle fueled by natural gas.

\subsection{Combustor Out let Temperature}

The reference system operates with a combustor outlet temperature of $1850^{\circ} \mathrm{F}$, which is several hundred degrees lower than the firing temperature of commercial turbines fueled by oil or gas. Table 5-2 and Figure 5-1 show the dramatic improvement in COE margin resulting from increasing the firing 
temperature to $2150^{\circ} \mathrm{F}$. The improvement is due to the increased power and efficiency of the higher temperature cycle. The progressive improvement is tempered somewhat at higher temperatures by the requirement for increased turbine blade cooling, which reduces the cycle efficiency, and by the increased cost of the higher temperature turbine hot parts.

Table 5-2. COE Sensitivity to Firing Temperature (CWM-Fueled Plant, HHV)

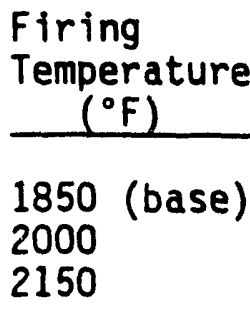

Net

Power

(MW)

231.3

267.3

301.1
Plant

Efficiency

(\%)

38.2

39.4

40.2
Capital

Cost

$(\$ / k W)$

\section{1,069}

967

925
COE Margin

11.0

16.9

19.9

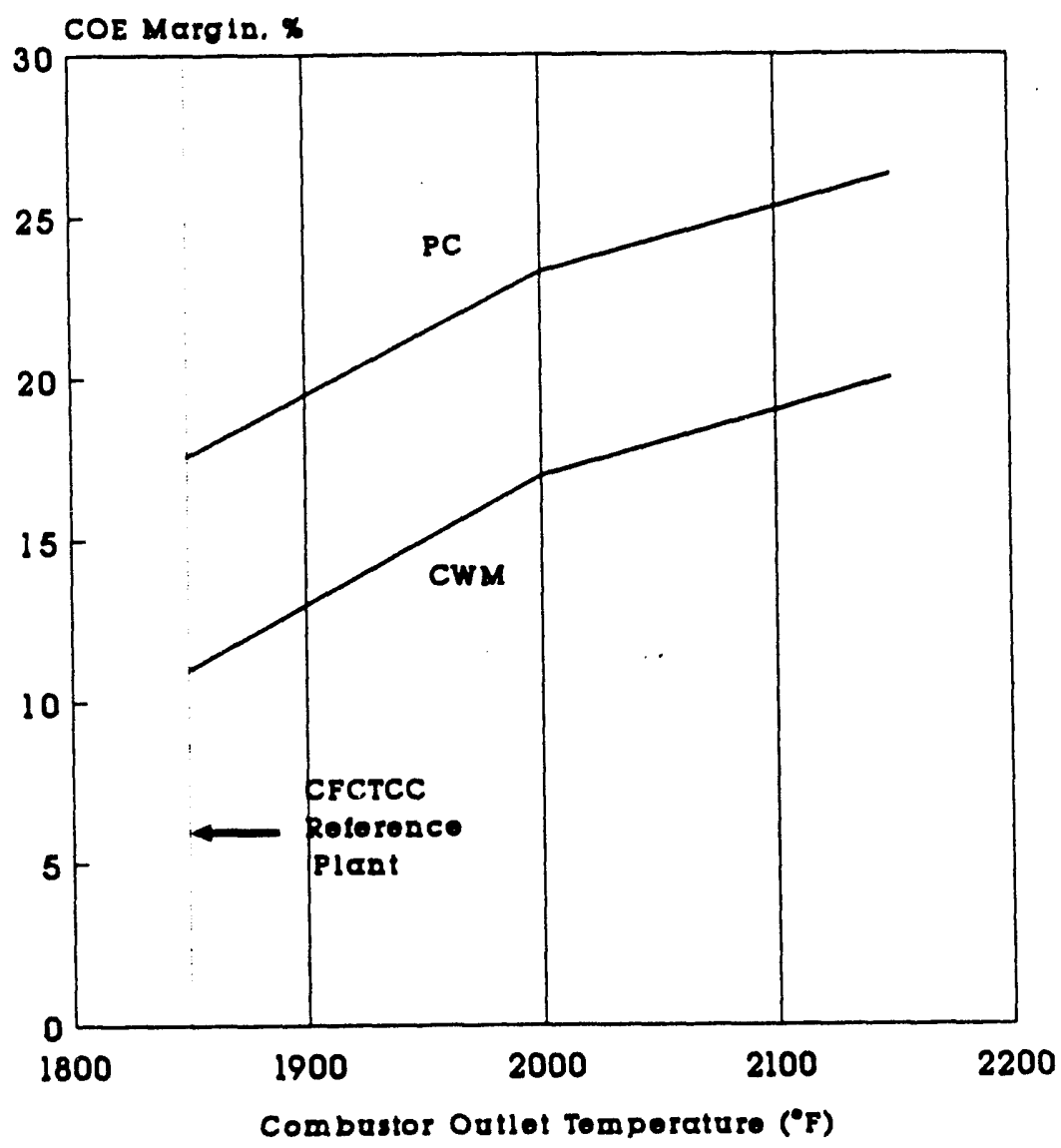

Figure 5-1. COE Margin vs. Firing Temperature 


\subsection{Slurry Chemical Expense}

In the CWM-fueled reference plant, the first year cost of slurry chemicals (dispersant, stabilizer, and $\mathrm{pH}$ modifier) is estimated to be $\$ 11.7 \mathrm{million}$, or 79.5 percent of the $\$ 14.8$-million total first year consumables cost. The complete consumable cost breakdown is listed in another section of this report.

For this same plant, consumables account for 21.7 percent of the total COE. A 10-percent reduction in chemicals cost, by reducing either the amount of chemicals used or their costs, would result in a reduction in COE of $0.100 \times 0.795 \times 0.217$, or 1.7 percent.

In the extreme case, if the slurry chemical cost were eliminated altogether, the COE would decrease by 17.2 percent from $\$ 84.0 / \mathrm{MWh}$ to $\$ 69.6 / \mathrm{MWh}$, and the COE margin would improve from 11.0 percent to 26.3 percent.

\subsection{Sulfur Capture}

During the slagging combustor tests, over 90 percent of the sulfur was captured in the primary combustion zone, but much of it escaped from the slag in the slag separator zone, resulting in a net sulfur capture efficiency for the complete rig of only about 50 percent. In the test rig, the slag is retained in the separation zone for the duration of the test, allowing the sulfur time to escape. It is thought that sulfur escape will be significantly reduced when a slag removal system is added, resulting in overall sulfur capture efficiencies of at least 90 percent.

The addition of more sorbent results in increased feedstock costs, slightiy decreased plant efficiency, and increased capital cost of the slag-handing equipment. Table 5-3 and Figure 5-2 project COE margins between -2.9 and +11.0 percent for CWM, and between 4.7 and 17.9 percent for dry pulverized coal, assuming that 90-percent of the sulfur can be captured using limestone with $\mathrm{Ca} / \mathrm{S}$ ratios between 2.0 and 8.0 . Each 1.0 increase in $\mathrm{Ca} / \mathrm{S}$ ratio results in an approximate 2.3-percent decrease in COE margin.

Table 5-3. COE Sensitivity to Ca/S Ratio (CWM-Fueled Plant with 90\% Sulfur Capture, HHV)

\begin{tabular}{|c|c|c|c|c|}
\hline $\begin{array}{l}\text { Limestone } \\
\text { Ca/S Ratio } \\
\text { (w/90\% capture) }\end{array}$ & $\begin{array}{l}\text { Net } \\
\text { Power } \\
\text { (MW) }\end{array}$ & $\begin{array}{c}\text { Plant } \\
\text { Eff iciency } \\
(\%) \\
\end{array}$ & $\begin{array}{c}\text { Capital } \\
\text { Cost } \\
(\$ / k W) \\
\end{array}$ & $\begin{array}{c}\text { COE } \\
\text { Margin } \\
(\%)\end{array}$ \\
\hline $\begin{array}{l}2.0 \text { (base) } \\
4.0 \\
6.0 \\
8.0\end{array}$ & $\begin{array}{l}231.3 \\
231.9 \\
232.4 \\
233.0\end{array}$ & $\begin{array}{l}38.2 \\
37.8 \\
37.4 \\
37.0\end{array}$ & $\begin{array}{l}1,069 \\
1,094 \\
1,116 \\
1,136\end{array}$ & $\begin{array}{l}+11.0 \\
+6.3 \\
+1.7 \\
-2.9\end{array}$ \\
\hline
\end{tabular}




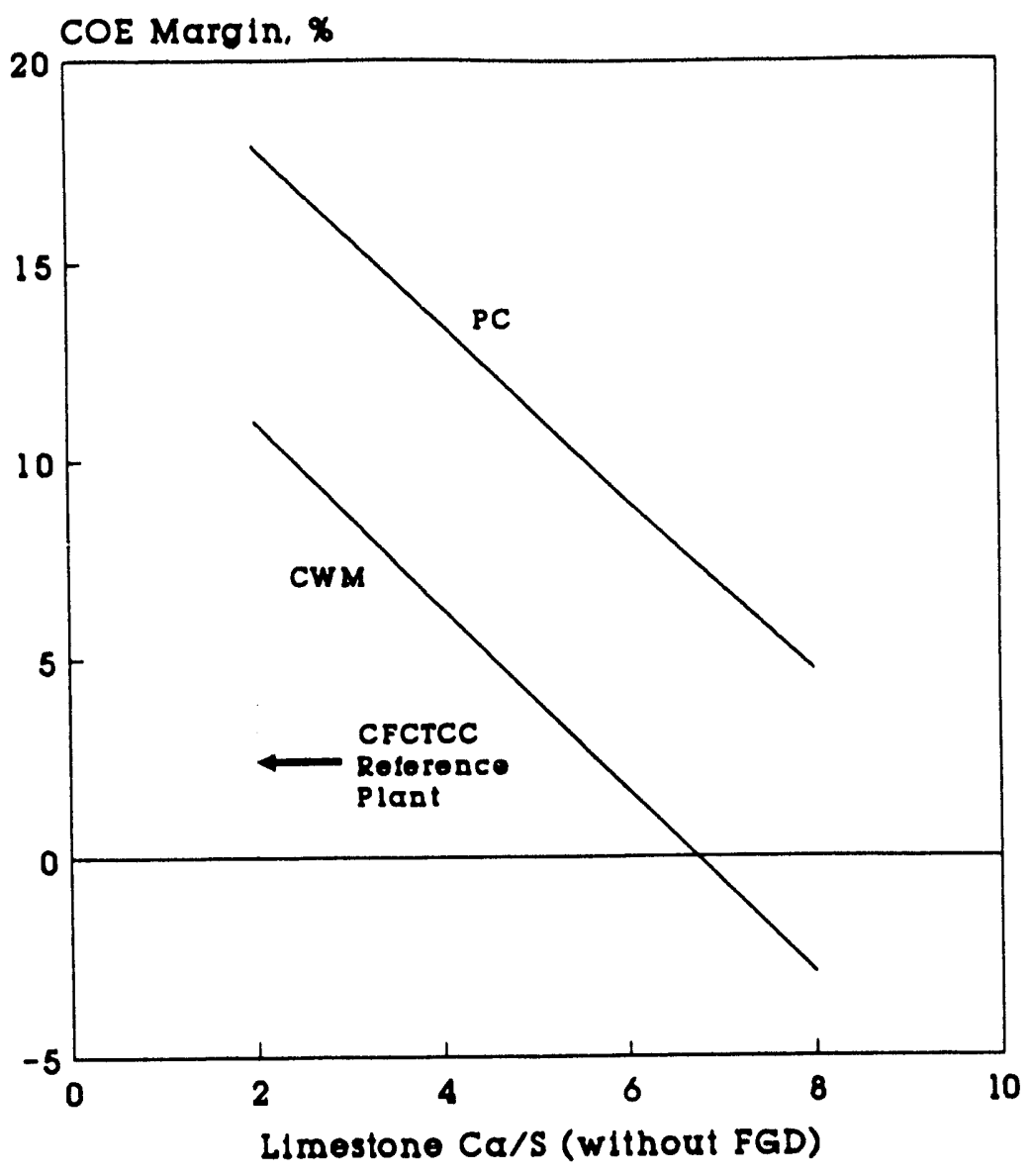

Figure 5-2. COE Margin vs. Ca/S Ratio

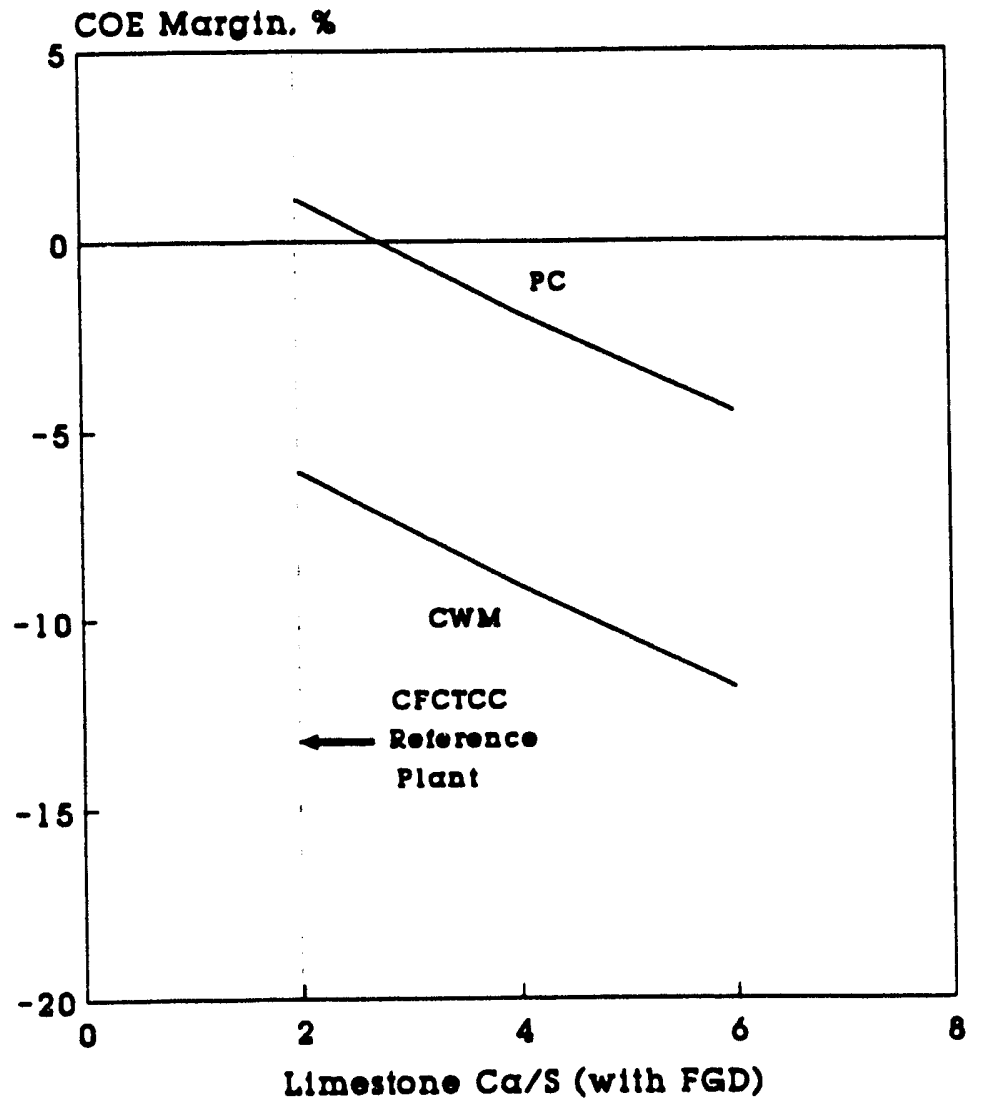

Figure 5-3. COE Margin for Plant with FGD 
If the slagging combustor is unable to remove all 90 percent of the sulfur, a FGD could be added to the plant, but at the cost of a considerable erosion of COE margin. As shown in Table 5-4 and Figure 5-3, the COE marg in for a plant with FGD ranges from 1 percent (for dry coal plant with a $\mathrm{Ca} / \mathrm{S}$ of 2.0 ) to -11.8 percent (for a CWM-fueled plant with a $\mathrm{Ca} / \mathrm{S}$ ratio of 6.0 ). The capital cost of the FGD depends mainly on gas volumetric flow rate, not sulfur removal ability. The change in COE margin with changing $\mathrm{Ca} / \mathrm{S}$ ratio is due to changes in feedstock cost, plant efficiency, and slag-removal equipment cost, as described above. The case with $\mathrm{Ca} / \mathrm{S}$ equal to 0.0 represents a plant in which all sulfur is captured by limestone in the FGD, and none is captured by the slagging combustor.

Table 5-4. COE Sensitivity to Ca/S Ratio (CWM-Fueled Plant with FGD, HHV)

\begin{tabular}{|c|c|c|c|c|}
\hline $\begin{array}{l}\text { Limestone } \\
\text { Ca/S Rat io } \\
\text { (w/FGD) }\end{array}$ & $\begin{array}{l}\text { Net } \\
\text { Power } \\
\text { (MW) }\end{array}$ & $\begin{array}{c}\text { Plant } \\
\text { Efficiency } \\
(\%) \\
\end{array}$ & $\begin{array}{c}\text { Capital } \\
\text { Cost } \\
(\$ / k W) \\
\end{array}$ & $\begin{array}{c}\text { COE } \\
\text { Margin } \\
(\%) \\
\end{array}$ \\
\hline $\begin{array}{l}0.0 \\
2.0 \\
4.0 \\
6.0\end{array}$ & $\begin{array}{l}226.4 \\
227.8 \\
229.0 \\
230.5\end{array}$ & $\begin{array}{l}37.7 \\
37.5 \\
37.3 \\
37.1\end{array}$ & $\begin{array}{l}1,205 \\
1,229 \\
1,247 \\
1,262\end{array}$ & $\begin{array}{r}-3.5 \\
-6.1 \\
-9.1 \\
-11.8\end{array}$ \\
\hline
\end{tabular}

Taconite, an iron-based sorbent, is a less reactive and less expensive alternative to limestone. The temperatures in the slagging combustor are much nigher than the normal operating range of this sorbent, and operation with $\mathrm{Fe} / \mathrm{S}$ ratios below 10 is expected to require a FGD to maintain the required 90-percent sulfur removal. Table 5-5 and Figure 5-4 show negative COE margins in all cases, due to the low sulfur capture efficiency of taconite and the increased capital cost of slag-removal equipment and of the FGD. The case with $\mathrm{Fe} / \mathrm{S}$ equal to 0.0 represents a plant in which all sulfur is captured by limestone in the FGD, and none is captured by the slagging combustor.

Table 5-5. COE Sensitivity to Taconite Fe/S Ratio (CWM-Fueled Plant, HHV)

\begin{tabular}{|c|c|c|c|c|}
\hline $\begin{array}{c}\text { Taconite } \\
\text { Fe/S Ratio } \\
\text { (w/FGD) } \\
\end{array}$ & $\begin{array}{l}\text { Net } \\
\text { Power } \\
\text { (MW) }\end{array}$ & $\begin{array}{c}\text { Plant } \\
\text { Efficiency } \\
(\%) \\
\end{array}$ & $\begin{array}{c}\text { Capital } \\
\text { Cost } \\
(\$ / k W) \\
\end{array}$ & $\begin{array}{c}\text { COE } \\
\text { Margin } \\
(\%)\end{array}$ \\
\hline $\begin{array}{r}0.0 \\
4.0 \\
6.0 \\
8.0 \\
10.0 \text { (no FGD) }\end{array}$ & $\begin{array}{l}226.4 \\
228.6 \\
229.2 \\
230.5 \\
232.5\end{array}$ & $\begin{array}{l}37.7 \\
36.7 \\
36.2 \\
35.7 \\
35.3\end{array}$ & $\begin{array}{l}1,205 \\
1,304 \\
1,347 \\
1,386 \\
1,280\end{array}$ & $\begin{array}{l}-3.5 \\
-27.0 \\
-39.7 \\
-52.4 \\
-53.4\end{array}$ \\
\hline
\end{tabular}

For a CWM-fueled, taconite-assisted plant with an $\mathrm{Fe} / \mathrm{S}$ ratio of 10.0 , the first year taconite cost is estimated to be $\$ 32$ million, or about 58 percent of the \$55-million total first year consumables cost, as itemized in Table 5-6. 


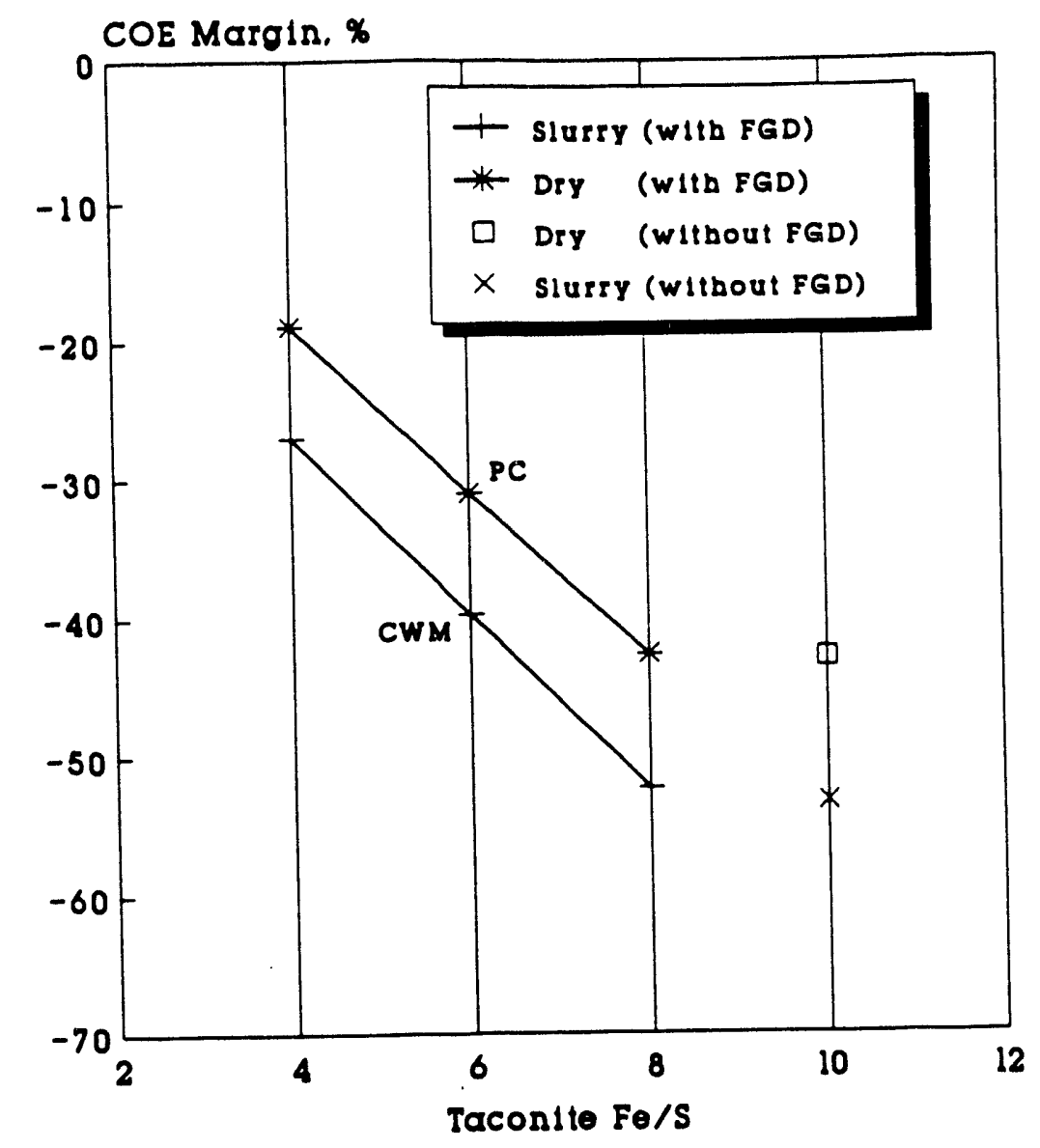

Figure 5-4. COE Margin vs. Fe/S Ratios with FGD

Table 5-6. Taconite and Other Consumable Costs

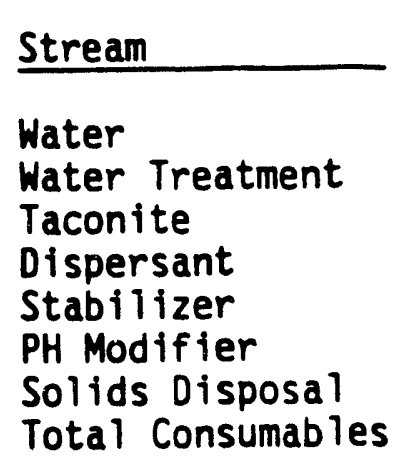

\begin{tabular}{|c|c|c|}
\hline $1 \mathrm{~b} / \mathrm{h}$ & $s / k 1 b$ & $k \$ / y r$ \\
\hline $\begin{array}{r}487,292 \\
280 \\
346,334 \\
2,192 \\
464 \\
1,669 \\
327,381\end{array}$ & $\begin{array}{r}0.08 \\
120.00 \\
15.00 \\
240.00 \\
2750.00 \\
167.43 \\
4.60\end{array}$ & $\begin{array}{r}250.80 \\
206.18 \\
31,855.77 \\
3,225.57 \\
7,822.14 \\
1,713.33 \\
10,146.16 \\
55,219.95\end{array}$ \\
\hline
\end{tabular}

For this same plant, consumables account for 46.8 percent of the total COE, as shown in Table 5-7. A 10-percent reduction in taconite cost, therefore, would result in a reduction in $\operatorname{COE}$ of $0.100 \times 0.58 \times 0.468$, or 2.7 percent. 
Table 5-7. COE with Taconite for CFCTCC - CWM

Total Plant Cost, $\$ / \mathrm{kW}$ $1,069.4$

Capital Charges, \$/MWh

42.32

Fixed Oper \& Maint, \$/MWh

9.90

Variable Oper \& Maint, $\$ / M W h$

4.24

Consumables, \$/MWh

Fue 1, \$/MWh

Levelized COE, \$/MWh

67.72

20.61

144.80

COE Margin (ref: $\$ 94.4 / \mathrm{MWh}$ )

In the extreme case, if the taconite cost were eliminated altogether, the COE would decrease by 27.1 percent from $\$ 144.80 / \mathrm{MWh}$ to $\$ 105.5 / \mathrm{MWh}$, and the COE marg in would improve from -53.4 percent to -11.8 percent, not enough to break even.

\subsection{Combustor Capital Cost}

The capital cost of the slagging combustor in a mature CWM-fueled plant is estimated to be $\$ 26.2$ million, or about 10.6 percent of the $\$ 247-m i 11$ ion total plant cost. (The capital cost breakdown is shown in another section of this report.) For this same plant, carrying charges based on these capital costs account for 40.8 percent of the total COE. The impact of a combustor cost reduction on COE is relatively minor.

A 10-percent reduction in slagging combustor cost, therefore, would result in a reduction in COE of $0.100 \times 0.106 \times 0.408$, or 0.44 percent.

In the extreme case, if the slagging combustor cost were eliminated altogether, the COE would decrease by 4.4 percent from $\$ 84.0 / \mathrm{MWh}$ to $\$ 80.3 / \mathrm{MWh}$, and the COE margin would improve from 11.0 percent to 14.9 percent. If the cost of the slagging combustor doubled to $\$ 52.4$ million, the COE would increase to $\$ 87.8 / \mathrm{MWh}$.

\subsection{Turbine Reblading Interval}

A critical factor in the successful development of a CFCTCC is the delivery of a suitable clean gas to the turbine inlet that is compatible with turbine components. Potentially higher particulate loadings and alkali levels within a direct coal-fired combustion turbine indicates that an economic trade-off should be considered between hot gas cleanup and turbine reblading intervals. In this study only the reblading interval of the turbine was considered.

Periodic replacement of corroded or eroded turbine blades affect the COE by increasing maintenance cost and reducing the operating availability of the turbine. Since there is not enough data on the effects of corrosion and erosion on turbine blade life, the COE was calculated for the range of values listed in Table 5-8. For each case, including the base case, the COE includes the materials and labor cost of opening the turbine and replacing worn-out rows of vanes and blades. 
Table 5-9 and Figure 5-5 show that reblading interval has little effect on COE margin as long as the shortest time between rebladings is at least 5,000 hours. At shorter reblading intervals, however, turbine down-time begins to reduce the capacity factor of the power plant. Blade lives of 2,000 and 1,000 hours reduce the nominal 70 -percent availability to 58 percent and 46 percent, respectively, which severely reduces the COE margin of the coal-fueled combined cycle.

Table 5-8. Turbine Reblading Interval

\begin{tabular}{|c|c|c|c|c|}
\hline $\begin{array}{l}\text { Reblading } \\
\text { Schedule }\end{array}$ & $\begin{array}{l}\text { Row } 1 \\
\text { (hours) }\end{array}$ & $\begin{array}{c}\text { Row } 2 \\
\text { (hours) }\end{array}$ & $\begin{array}{l}\text { Row } 3 \\
\text { (hours) }\end{array}$ & $\begin{array}{r}\text { Row } 4 \\
\text { (hours) }\end{array}$ \\
\hline $\begin{array}{l}\text { Schedule } 1 \\
\text { Schedule } 2 \text { (base) } \\
\text { Schedule } 3 \\
\text { Schedule } 4 \\
\text { Schedule } 5 \\
\text { Schedule } 6\end{array}$ & $\begin{array}{r}40,000 \\
25,000 \\
10,000 \\
5,000 \\
2,000 \\
1,000\end{array}$ & $\begin{array}{r}60,000 \\
50,000 \\
20,000 \\
10,000 \\
4,000 \\
2,000\end{array}$ & $\begin{array}{r}60,000 \\
50,000 \\
20,000 \\
10,000 \\
4,000 \\
2,000\end{array}$ & $\begin{array}{r}100,000 \\
90,000 \\
50,000 \\
25,000 \\
10,000 \\
5,000\end{array}$ \\
\hline
\end{tabular}

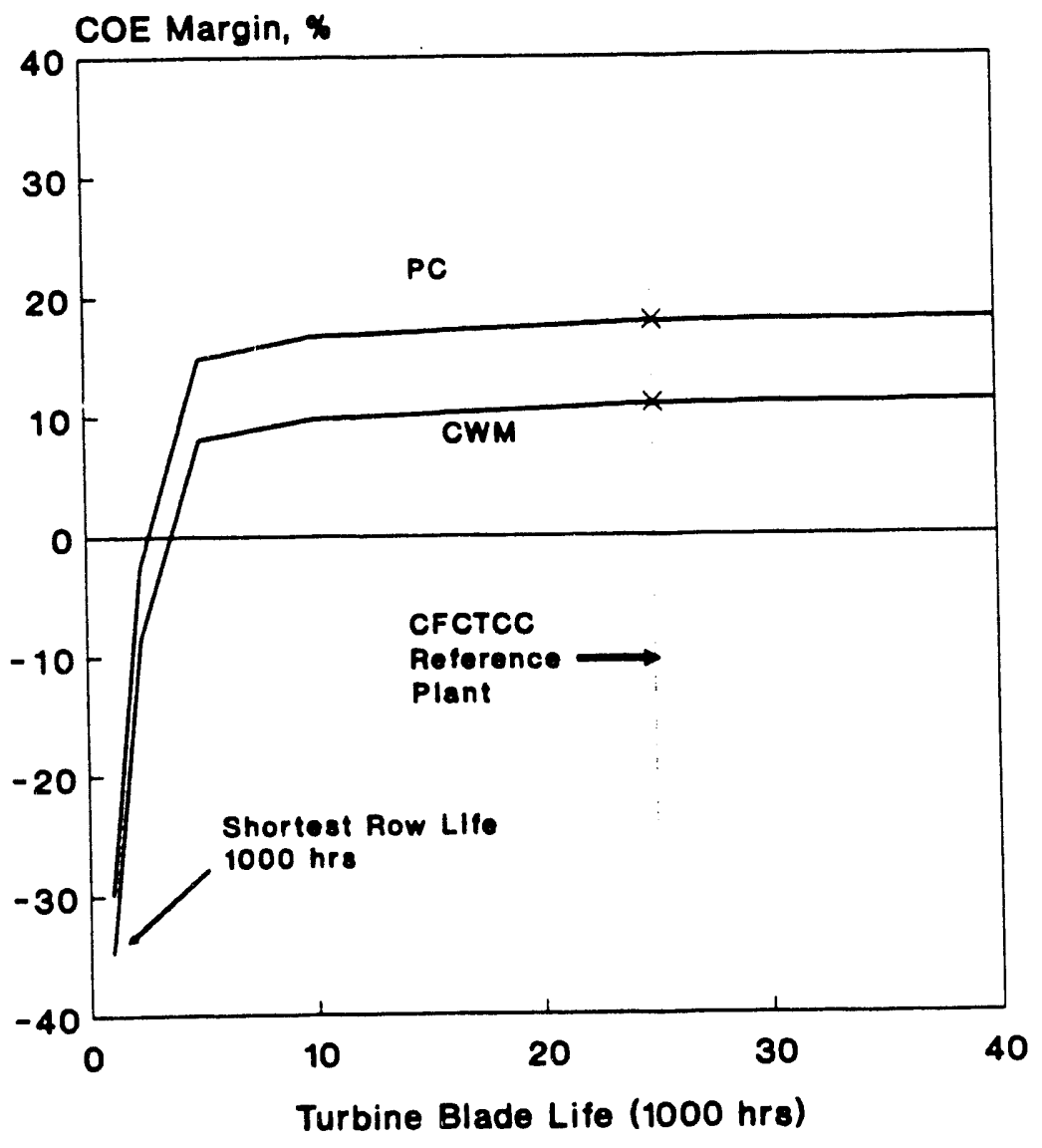

Figure 5-5. COE Margin vs. Turbine Reblading Intervals 
Table 5-9. COE Sensitivity to Reblading Interval

(CWM-Fue ied Plant, HHV)

Shortest

Blade Life

(hrs)

40,000

25,000 (base)

10,000

5,000

2,000

1,000

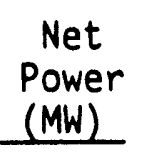

231.3

231.3

231.3

231.3

231.3

231.3
Plant

Efficiency

(\%)

38.2

38.2

38.2

38.2

38.2

38.2
Capital

Cost

$(\$ / \mathrm{kW})$

1,069

1,069

1,069

1,069

1,069

1,069
COE Margin

$(\%)$

11.2

11.0

9.8

8.1

$-8.5$

$-34.7$

\subsection{Combustor Pressure Loss}

The pressure loss through the combustor-and-cyclone flow path affects the expansion pressure ratio of, and the power produced by, the gas turbine. Table 5-10 and Figure 5-6 show that a 1-percent increase in pressure drop results in a 0.3-percent reduction in COE margin. This effect is minor compared with the effects of other parameters such as combustor outlet temperature and sulfur capture effectiveness (discussed in other sections).

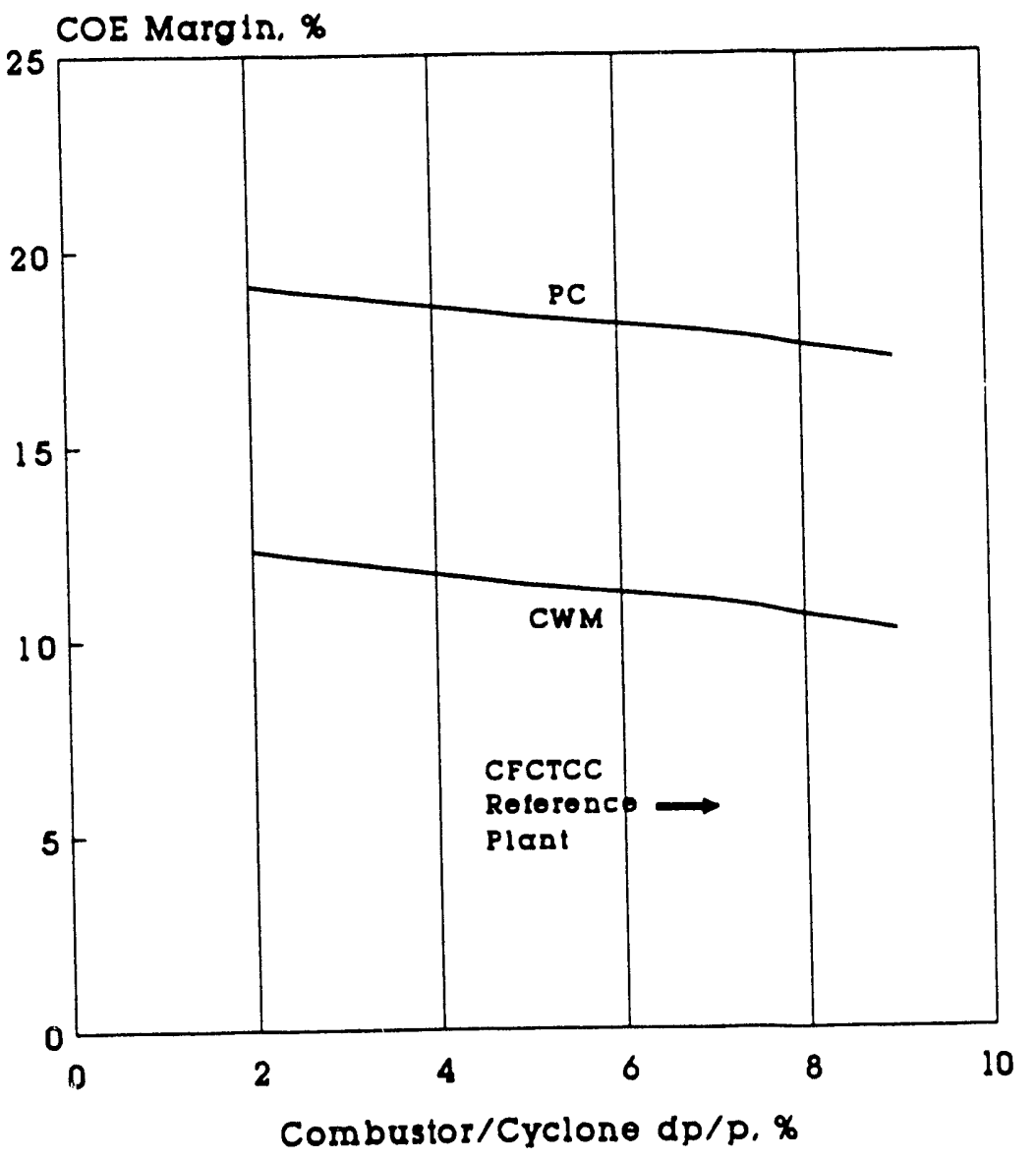

Figure 5-6. COE Margin vs. Combustor/Cyclone Pressure Drop 
Table 5-10. COE Sensitivity to Combustor Pressure Loss

(CWM-Fueled Plant, HHV)

\begin{tabular}{|c|c|c|c|c|}
\hline $\begin{array}{l}\text { Combustor } \\
\text { Pressure Loss } \\
(\%)\end{array}$ & $\begin{array}{l}\text { Net } \\
\text { Power } \\
\text { (MW) }\end{array}$ & $\begin{array}{c}\text { Plant } \\
\text { Efficiency } \\
(\%) \\
\end{array}$ & $\begin{array}{c}\text { Capital } \\
\text { Cost } \\
(\$ / k W) \\
\end{array}$ & $\begin{array}{c}\text { COE } \\
\text { Margin } \\
(\%) \\
\end{array}$ \\
\hline $\begin{array}{l}2.0 \\
5.0 \\
7.0 \text { (base) } \\
9.0\end{array}$ & $\begin{array}{l}234.7 \\
232.6 \\
231.2 \\
229.5\end{array}$ & $\begin{array}{l}38.8 \\
38.5 \\
38.2 \\
37.9\end{array}$ & $\begin{array}{l}1,054 \\
1,064 \\
1,069 \\
1,080\end{array}$ & $\begin{array}{l}12.3 \\
11.4 \\
11.0 \\
10.2\end{array}$ \\
\hline
\end{tabular}

\subsection{Combustor Heat Rejection}

In the proposed configuration, the high-temperature zones of the slagging combustor are cooled by circulating water from the HRSG high-pressure boiler, effectively removing energy from the gas turbine cycle and moving it directly to the steam turbine cycle. This shift in energy utilization increases the power produced by the plant while it reduces the overall plant thermal efficiency. These offsetting effects reduce the per-kilowatt capital cost but increase the per-kilowatt-hour operating cost. The net economic result is that a 10-percent increase in combustor cooling (based on LHV heat released) causes only a 0.2-percent decrease in COE margin. As long as the cooling energy is returned to the steam cycle, the COE margin is virtually insensitive to combustor heat rejection.

The effect of combustor cooling on COE margin is shown in Table 5-11 and Figure 5-7. For this set of data, all of the heat rejected by the combustor is used by the steam cycle.

Table 5-11. COE Sensitivity to Combustor Cooling (Rejected Heat Used By Stean Cycle, HHV)

\begin{tabular}{|c|c|c|c|c|}
\hline $\begin{array}{l}\text { Combustor } \\
\text { Cooling } \\
\text { (\% of QLHV) }\end{array}$ & $\begin{array}{l}\text { Net } \\
\text { Power } \\
\text { (MW) }\end{array}$ & $\begin{array}{c}\text { Plant } \\
\text { Efficiency } \\
(\%) \\
\end{array}$ & $\begin{array}{c}\text { Capital } \\
\text { Cost } \\
(\$ / k W) \\
\end{array}$ & $\begin{array}{c}\text { COE } \\
\text { Margin } \\
(\%) \\
\end{array}$ \\
\hline $\begin{array}{r}0.0 \\
6.0 \\
8.0 \text { (base) } \\
10.0\end{array}$ & $\begin{array}{l}216.7 \\
227.3 \\
231.3 \\
235.6\end{array}$ & $\begin{array}{l}39.6 \\
38.6 \\
38.2 \\
37.9\end{array}$ & $\begin{array}{l}1,071 \\
1,069 \\
1,069 \\
1,067\end{array}$ & $\begin{array}{l}11.9 \\
11.2 \\
11.0 \\
10.8\end{array}$ \\
\hline
\end{tabular}




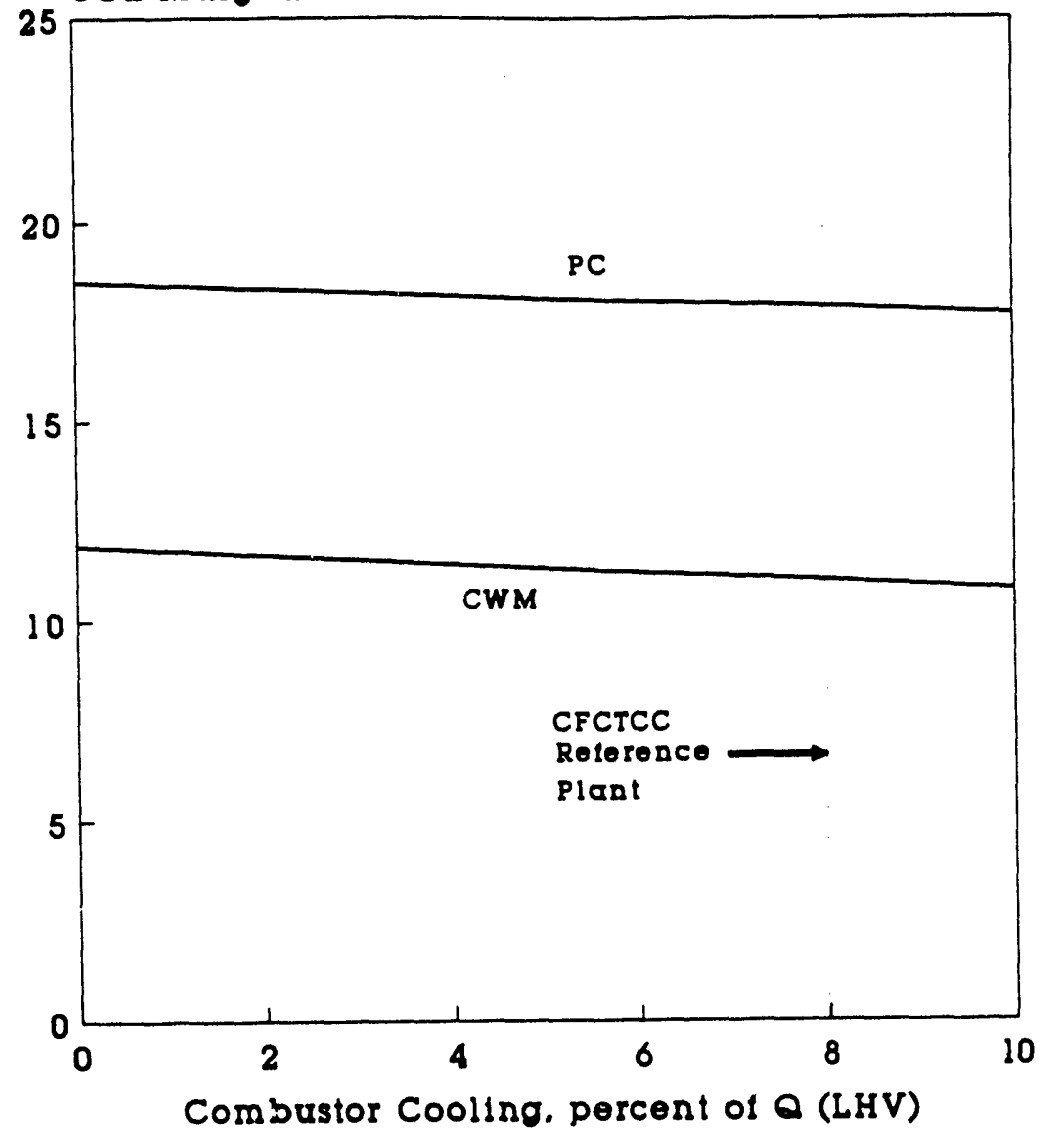

Figure 5-7. COE Margin vs. Combustor Cooling (CWM-Fueled Plant; Rejected Heat Used by Steam Cycle)

If, instead of being used by the steam turbine cycle, the energy from combustor cooling is rejected to the environment, the impact on COE is dramatically different. Table 5-12 and Figure 5-8 show COE margins between 5.8 and 8.4 percent resulting from unrecovered combustor cooling losses, compared with the 11-percent margin of the Reference Plant.

Table 5-12. COE Sensitivity to Combustor Cooling (CWM-Fueled Plant; Energy Lost from Cycle, HHV)

\begin{tabular}{lcccc}
$\begin{array}{l}\text { Combustor } \\
\text { Cooling } \\
(\% \text { of QLHV) }\end{array}$ & $\begin{array}{c}\text { Net } \\
\text { Power } \\
(\text { MW })\end{array}$ & $\begin{array}{c}\text { Plant } \\
\text { Efficiency } \\
(\%)\end{array}$ & $\begin{array}{c}\text { Capital } \\
\text { Cost } \\
(\$ / \mathrm{kW})\end{array}$ & $\begin{array}{c}\text { COE } \\
\text { Margin } \\
(\%)\end{array}$ \\
\hline 0.0 & 216.7 & 39.6 & 1,071 & 11.9 \\
6.0 & 217.1 & 36.8 & 1,085 & 8.4 \\
8.0 & 217.3 & 35.9 & 1,090 & 7.1 \\
10.0 & 217.6 & 35.0 & 1,095 & 5.8 \\
8.0 (Base, ref) & 231.3 & 38.2 & 1,069 & 11.0
\end{tabular}




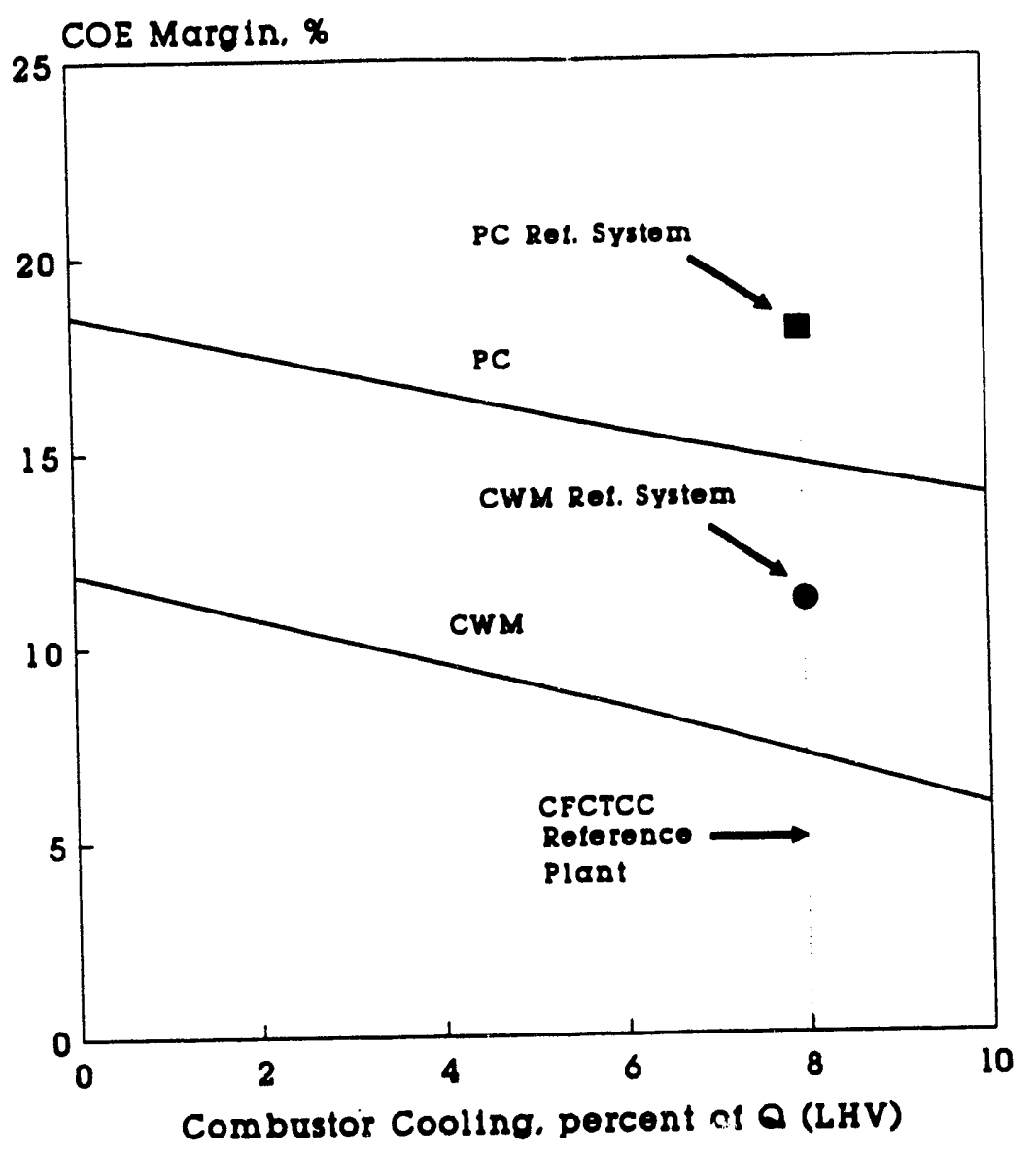

Figure 5-8. COE Margin vs. Combustor Cooling (Energy Lost from Cycle)

\subsection{Natural Gas Prices}

In recent years natural gas prices have been more volatile than coal prices. Both the CWM and dry-coal plants have higher COEs than a combined cycle fueled by natural gas at a price of $\$ 4.00 / M M B t u$, but a change in gas price could make the coal-fueled combined cycle less expensive to operate than its gas-fueled counterpart.

Figure 5-9 shows the strong relationship between natural gas price and $C O E$ margin for coal-fueled plants. Over a range of gas prices from $\$ 2$ to $\$ 20 / M B t u$ (gas/coal costs of 1.1 to 11.1), the COE margins of dry-coal-fueled Reference Systems range from -44 percent to +76 percent. The corresponding values for the CWM-fueled plants are -56 percent and +74 percent. COE "break-even" values occur at Gas/Coal price ratios around 2.22 (\$3.99/MBtu gas) for the CWm-fueled plant, and around 1.98 (\$3.56/MBtu gas) for the dry-coal-fueled plant. 


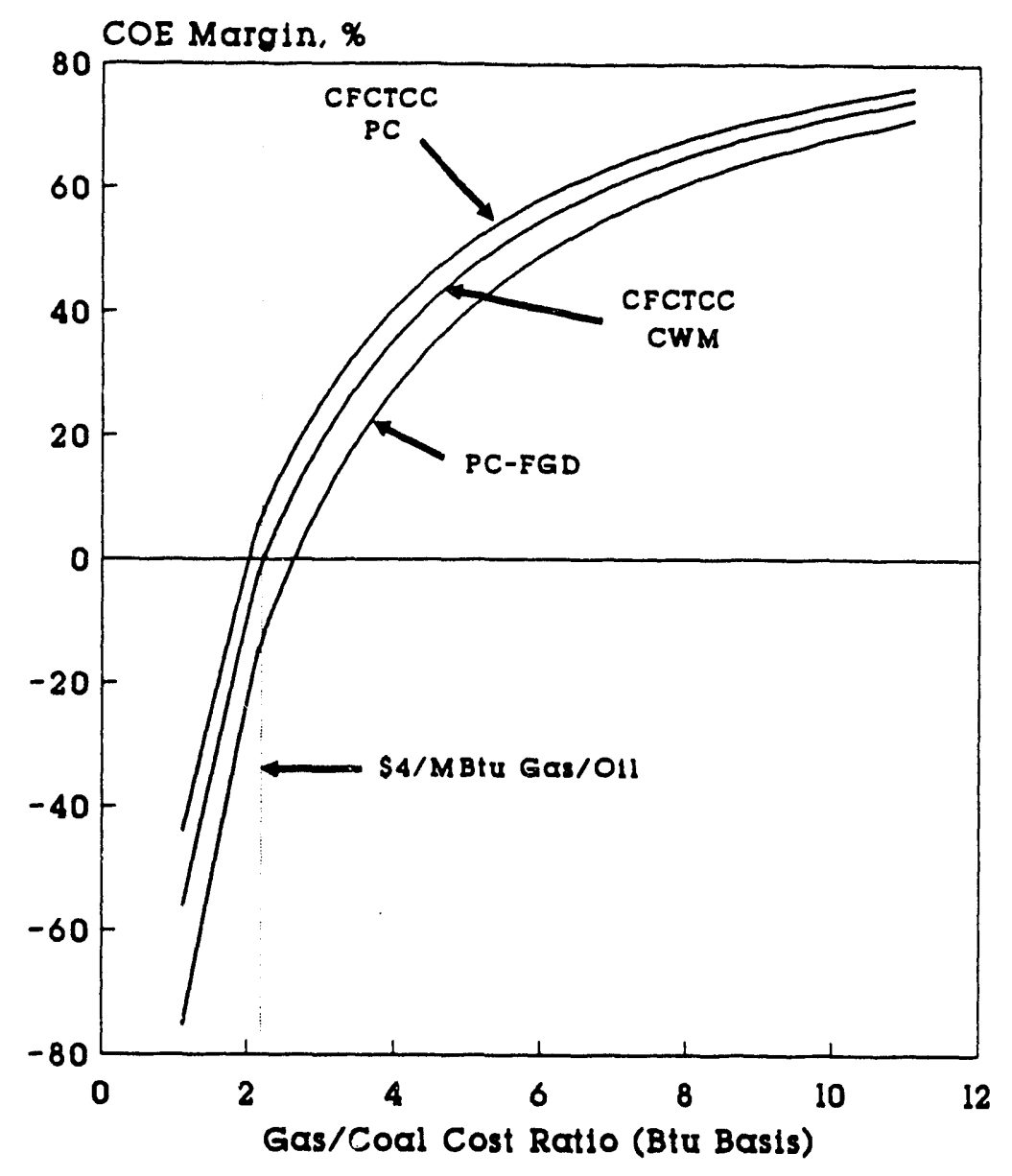

Figure 5-9. COE Margin Sensitivity to Natural Gas Prices

\subsection{Coal Benefication}

The effect of various types of coal cleaning on the thermal and economic performance of the PC-Fired Reference System was evaluated in a sensitivity study. Direct Coal-Fueled Reference Systems with no coal cleaning were compared to systems with four different types of physical coal cleaning (including the LICADO process) and two types of chemical coal cleaning. The LICADO coal cleaning process is described in Appendix $A$ and brief descriptions of the other coal cleaning processes are given in Appendix B. The PC-Fueled Reference System without coal cleaning had the best efficiency, plant cost, and COE margin, as shown in the ranked comparisons in Table 5-13. In general, physical coal cleaning alternatives ranked better than the chemical cleaning alternatives. The conventional pulverized coal steam power plant with flue gas desulfurization (PC/FGD) placed last or second-last in all categories. 
Table 5-13. Comparative Rankings (1=best, 9=worst)

REFERENCE SYSTEMS:

CWM-Fueled

PC-Fueled

COMPARISON PLANTS:

\author{
Plant \\ Efficiency \\ (Table 5-14)
}

3
1

PC/FGD

PC/LICADO

PC/PCC-1

$P C / P C C-2$

$P C / P C C-3$

PC/TRW

PC/Kennecott

\author{
Plant \\ Cost \\ (Table 5-15)
}

COE
Margin
$($ Table $5-16)$

5

1

The thermal performance of each of the plants is summarized in Table 5-14. The HHV efficiencies of both Reference Systems and the TRW chemical cleaning process are above 38 percent, and all of the direct coal-fueled gas turbine alternative plants have efficiencies above 36 percent. The relatively large auxiliary requirements of the Kennecott process reduces the net power output and the efficiency by about 4 percent, but this reduction is offset by the high energy recovery of the process.

Table 5-14. Performance Comparisons

$\begin{array}{cccccc}\text { Gas } & \text { Stm } & & & & \\ \text { Turb } & \text { Turb } & \text { Auxil } & \text { Net } & \text { Coal } & \text { HHV } \\ \text { Power } & \text { Power } & \text { Power } & \text { Power } & \text { Feed } & \text { Eff. } \\ \text { (MW) } & \text { (MW) } & \text { (MW) } & \text { (MW) } & (1 \mathrm{~b} / \mathrm{h}) & (\%)\end{array}$

REFERENCE SYSTEMS:

$\begin{array}{lcccccc}\text { REFERENCE SYSTEMS: } & 172.1 & 63.9 & -4.7 & 231.3 & 152,289 & 38.34 \% \\ \begin{array}{l}\text { CWM-Fueled } \\ \text { PC-Fueled }\end{array} & 161.3 & 62.6 & -2.0 & 221.8 & 139,707 & 39.98 \% \\ \text { COMPARISON PLANTS: } & & & & & & \\ \text { PC/FGD } & - & - & - & 220.0 & 161,653 & 34.26 \% \\ \text { PC/LICADO } & 161.2 & 63.2 & -4.1 & 220.3 & 166,551 & 37.84 \% \\ \text { PC/PCC-1 } & 161.3 & 63.1 & -2.3 & 222.1 & 151,220 & 36.97 \% \\ \text { PC/PCC-2 } & 161.3 & 63.2 & -2.5 & 221.9 & 151,372 & 36.91 \% \\ \text { PC/PCC-3 } & 161.3 & 63.1 & -2.3 & 222.1 & 151,239 & 36.96 \% \\ \text { PC/TRW } & 161.3 & 64.2 & -3.9 & 221.5 & 140,169 & 39.79 \% \\ \text { PC/Kennecott } & 161.3 & 63.9 & -12.1 & 213.1 & 146,875 & 36.53 \%\end{array}$

Reference Systems with no coal cleaning or with physical coal cleaning other than LICADO cleaning have total plant costs under $\$ 1200 / \mathrm{kW}$, as shown in Table 5-15. The LICADO process equipment adds about $\$ 200 / \mathrm{kW}$ to the cost of the plant, making it cost about the same as a Reference System plant with chemical coal cleaning. The addition of coal cleaning equipment adds between $\$ 21 / \mathrm{kW}$ and $\$ 193 / \mathrm{kW}$ to the capital cost. 
The total plant cost of the PC/FGD comparison plant is about $\$ 400 / \mathrm{kW}$ more expensive than the Reference Systems without coal cleaning.

Table 5-15. Capital Cost Comparisons

$\begin{array}{cc}\begin{array}{c}\text { Coal } \\ \text { Processing } \\ (\$ / \mathrm{kW})\end{array} & \begin{array}{l}\text { Total } \\ \text { Plant } \\ (\$ / \mathrm{kW})\end{array} \\ 116 & 1,169 \\ 162 & 1,132 \\ & \\ - & 1,519 \\ 333 & 1,300 \\ 183 & 1,145 \\ 198 & 1,159 \\ 196 & 1,158 \\ 290 & 1,246 \\ 355 & 1,350\end{array}$

The most important comparison of the plants is that of their COE margins (compared to the PC/FGD plant), as shown in Table 5-16. In the table, operating and maintenance (O\&M) costs are presented as a single value that includes both fixed and variable costs. The PC-Fueled Reference System plant w: thout cOal cleaning shows the most favorable COE margin, followed by conventional physical coal cleaning, the CWM-Fueled plant without coal cleaning, LICADO coal cleaning, and chemical coal cleaning. The case with the Kennecott process was estimated to have a higher COE than that of the PC/FGD plant.

Table 5-16. COE Comparisons

$\begin{array}{cccccc}\text { Capital } & \text { F\&V } & \text { Consum- } & & \text { Levelized } & \text { COE } \\ \text { Charges } & \text { O\&M } & \text { ables } & \text { Fuel } & \text { COE } & \text { Margin } \\ (\$ / M W h) & (\$ / M W h) & (\$ / M w h) & (\$ / M W h) & (\$ / M W h) & (\%)\end{array}$

REFERENCE SYSTEMS:

CWM-Fueled

PC-Fueled

34.3

35.9

12.5

13.2

18.2

10.2

49.3

41.1

36.4

36.8

36.8

39.6

43.1
18.6

15.5

14.3

14.4

14.4

15.0

16.1
5.3

9.9

9.9

9.8

9.9

15.1

21.9
19.0

18.2

84.0

77.5

$11.0 \%$

$17.9 \%$

$\begin{array}{rrr}21.2 & 94.4 & -0-\% \\ 19.2 & 85.7 & 9.2 \% \\ 19.7 & 80.2 & 15.1 \% \\ 19.7 & 80.7 & 14.5 \% \\ 19.7 & 80.8 & 14.5 \% \\ 18.3 & 88.1 & 6.7 \% \\ 19.9 & 101.0 & -7.0 \%\end{array}$

The results of this sensitivity study show that the PC-Fueled gas turbine combined cycle has the best thermal and economic performance when used without supplemental coal cleaning; the sulfur is most effectively removed by the slagging combustor, not by an upstreain process. 


\section{PLANT DESCRIPTION}

The coal-fueled gas turbine combined cycle power plant is described in the the following sections:

Section 6.1 Fuel Processing

Section 6.2 Combustion Turbine Assembly

Section 6.3 Steam Turbine Cycle

Section 6.4 Slag Disposal System

\subsection{Fuel Processing}

The fuel processing facility performs all the functions needed to convert coal as received into a slagging combustor fuel, whether it is a coal-water slurry or dry pulverized coal. Table 6-1 is a brief functional overview of the two fuel processing systems.

Table 6-1. Fuel Processing Characteristics

\section{Turbine Fuel}

Receiving and Storage

Reclaim and Storage

Crushing, Drying and Storage

Pulverizing, Grinding

Slurry Production

Slurry Storage

Fuel Injection

Refuse Reclaim \& Disposal

Site Work

Miscellaneous

\section{Dry Coal}

$x$

$x$

$x$

$X$

$-$

$\bar{x}$

$\hat{x}$

$x$

$x$
$60 / 40$ CWM

$x$

$x$

$\bar{x}$

$x$

$x$

$x$

$x$

$x$

$x$

Table 6-2 characterizes the two coal fuels. The delivered coal in both cases is Pittsburgh No. 8.

Table 6-2. Coal and CWM Characteristics

\section{Turbine Fuel}

Carbon

Hydrogen

Nitrogen

oxygen

Sulfur

Moisture

Ash

Higher Heating Value

Dry Coal 60/40 CWM

74.45

4.97

1.51

6.17

3.00

2.51

7.39

13,555

$$
44.67
$$

2.98

0.91

3.70

1.80

41.51

4.43

8,133 $\%(w t)$

$\%(w t)$

$\%(w t)$

$\%(w t)$

$\%(w t)$

$\%(w t)$

$\%$ (wt)

Btu/lb 
The slurry processing facility and the dry coal processing facility are described below in greater detail.

\section{Slurry Processing Facility}

The coal slurry production facility supplies all the fuel for the 233 MW gas turbine combined cycle operating at 70-percent capacity factor. This facility is located at the power plant.

The fuel preparation facility converts Pittsburgh No. 8 lump coal into a coal-water fuel. The fuel processing consists of four major processes: coal receiving and storage, coal reclaim and storage, coal slurry production, and slurry storage and feed.

Receiving and Storage. Pittsburgh No. 8 coal, sized at $1-1 / 2^{\prime \prime} \times 0^{\prime \prime}$, is received at the power plant from unit trains consisting of 60 or 70100 -ton capacity bottom-dump cars. The rail unloading system consists of a double track with unloading hoppers installed beneath the railroad siding. The cars can be thawed, if needed, by electrical infrared radiant heaters. Two car shakers are provided to assist in dumping the cars. Vibrating feeders beneath the track hoppers feed coal to an inclined belt conveyor, which delivers coal to the active storage pile. A telescopic chute provides minimized dusting as coal discharges to the pile.

Two coal piles are provided: active and inactive. The active pile, which contains enough coal for 72 hours of operation at rated capacity, is located at the conveyor delivery point. The adjacent inactive coal storage pile is designed to store enough coal for 60 days of normal operation.

Reclaim and Storage. The reclaim system transfers coal from the coal pile to the fuel processing area. Coal is conveyed from two reclaim hoppers, located under the active storage pile, to the inclined belt conveyor by two vibrating feeders. The belt conveyor discharges coal onto a double-deck screen that passes $1 / 4^{\prime \prime} \times 0 "$ coal to a transfer chute. A hammer mill reducies the rest of the coal to the same size. A 456-foot belt conveyor moves the coal from the screen and hammer mill to two 1,000-ton slurry feed bins.

Cwi Production. The fuel production rate was calculated to be $470 \mathrm{gpm}$. The slurry facility is designed for a production rate of $550 \mathrm{gpm}$ to allow for 24 hours of maintenance per week. Under normal conditions, the required $470 \mathrm{gpm}$ is sent to the combustion turbine while $80 \mathrm{gpm}$ goes to storage.

The major components of the slurry production facility are:

Ball Mill - The ball mill is a wet grinding device that converts $1 / 4^{\prime \prime} \times 0 "$ coal into coal particles less than 100 mesh ( 150 microns) in size. Oversize particles are recycled through the ball mill by a belt conveyor.

Sieve Bend - The ball mill discharge is diluted to 12 percent solids, then screened for oversize particles in two sieve bends before flowing to the centrifuge dryers. 
Centrifuge Dryers - Ten high-speed centrifuges remove moisture to achieve a final dry coal flow with 6 percent moisture.

Slurry Preparation - Dried coal is discharged to the coal-water mixing tanks, where chemical additives and additional water are added to produce the required slurry composition. Demineralized water used to minimize any alkali and other trace metal contamination.

Refuse Reclaim and Disposal - The tailings from the drying mills are collected into a static thickener, from which processed water is pumped to the plant water holding tank for recirculation. A waste slurry containing 20 percent solids is pumped to two high-speed centrifuges, which dry the refuse to 6 -percent moisture. This refuse is delivered to an off-site ash disposal facility.

CWM Storage and Feed. The slurry is collected in an agitated sump for distribution to either the temporary storage tank or the gas turbine combustor. The three-day supply of stored slurry is mixed with a stabilizer to assure the stability of the mixture during storage. Three pumps transport 550 gpm of slurry to the fuel tank so the combustor can be fueled at full load while the storage tank is being replenished at $80 \mathrm{gpm}$.

\section{Dry Coal Processing Facility}

The dry coal production facility supplies all the fuel for the $222 \mathrm{MW}$ combustion turbine combined cycle operating at 70-percent capacity factor. This facility is located at the power plant.

The fuel preparation facility converts Pittsburgh No. 8 lump coal into a pulverized coal fuel. The fuel processing consists of four major processes: receiving and storage, reclaim and storage, crushing and storage, and coal injection.

Receiving and Storage. Pittsburgh No. 8 coal, sized at $1-1 / 2^{\prime \prime} \times 0^{\prime \prime}$, is received at the power plant from unit trains consisting of 60 or 70100 -ton capacity bottom-dump cars. The rail unloading system consists of a double track with unloading hoppers installed beneath the railroad siding. The cars can be thawed, if needed, by electrical infrared radiant heaters. Two car shakers are provided to assist in dumping the cars. Vibrating feeders beneath the track hoppers feed coal to an inclined belt conveyor, which delivers coal to the active storage pile. A telescopic chute provides minimized dusting as coal discharges to the pile.

Two coal piles are provided: active and inactive. The active pile, which contains enough coal for 72 hours of operation at rated capacity, is located at the conveyor delivery point. The adjacent inactive coal storage pile is designed to store enough coal for 60 days of normal operation.

Reclaim and Storage. The reclaim system transfers coal fron the coal pile to the fuel processing area. Coal is conveyed from two reclaim hoppers, located under the active storage pile, to the inclined belt conveyor by two vibrating feeders. The belt conveyor discharges coal onto a double-deck screen that 
passes $1 / 4^{\prime \prime} \times 0^{\prime \prime}$ coal to a transfer chute. A hammer mill reduces the rest of the coal to the same size. A 456-foot belt conveyor moves the coal from the screen and hammer mill to two 1,000-ton feed bins.

Crushing and Storage. The coal is conveyed from the feed bins to secondary crushers and dryers by vibrating feeders. The product coal is conveyed to surge bins, which feed three 50-percent pulverizers. The pulverizer system, which includes baghouse recovery, feeds the coal injection system through a set of lock hoppers.

Coal Injection. Pulverized coal is injected into the combustors by a Petrocarb-type lock hopper system. This 100-percent redundant system injects coal at a rate of $140,0001 \mathrm{~b} / \mathrm{hr}$.

\subsection{Combustion Turbine Assembly}

The combustion turbine assembly is a pedestal-mounted engine supported by two bearings on a single shaft. The assembly includes an axial flow compressor, an external combustor, a reaction turbine, and associated piping and wiring. The assembly is shipped with rotor in place. The rotor is supported by two tilting pad journal bearings and a double-acting, tilting pad thrust bearing. The engine uses cold-end drive with a rigid coupling at drive end. The turbine uses horizontal split case construction. The first row of vanes can be replaced through access ports, without lifting the cylinder covers.

The main components of the combustion turbine assembly are:

- Multi-stage axial flow compressor

- External combustion assembiy

- Four-stage reaction type turbine

The combustion turbine assembly also includes a start-up fuel system with starting air atomizing; fire detection and protection of exhaust end bearing; inlet silencing to $59 \mathrm{dbA}$; an enclosure with ventilation and lighting; and, a Halon fire protection system.

Table 6-3 summarizes the thermal performance of both reference combustion turbines.

Table 6-3. Combustion Turbine Performance Data

Turbine Fuel

Turbines per Plant

Cycle Pressure Ratio

Firing Temperature

Expander Power

Compressor Power

Auxiliary Power

Losses

Combustion Turbine Net Power

$$
\begin{array}{r}
\text { Ory Coal } \\
2 \\
14.0 \\
1850 \\
419,829 \\
(253,885) \\
(581) \\
(4,059) \\
\hline 161,304
\end{array}
$$

$60 / 40$ CWM

\begin{tabular}{rc}
2 & \\
14.0 & $\mathrm{~atm}$ \\
1850 & $\circ \mathrm{F}$ \\
430,883 & $\mathrm{~kW}$ \\
$(253,861)$ & $\mathrm{kW}$ \\
$(620)$ & $\mathrm{kW}$ \\
$\frac{(4,267)}{172,136}$ & $\mathrm{~kW}$ \\
\hline $\mathrm{kW}$
\end{tabular}


The combustion turbine expander is cooled by two air streams from the compressor as shown in Figure 2-4. Water cooling of the slagging combustor is used to augment steam production in the HRSGS. Stream data for both the CWM-fueled and dry coal-fueled cases are tabulated in Table 6-4.

Table 6-4. Combustion Turbine Stream Data

\section{CWM-FUELED SYSTEM \\ LoC Description}

17 Compressor Air Inlet

19 Compressor LP Cooling Exit

20 Compressor HP Cooling Exit

24 Compressor Air Exit

34 Combustor Gas Exit

35 Expander HP Cooling Inlet

36 Expander LP Cooling Inlet

40 Expander Exhaust

47 Combustor Fuel Inlet

120 Cooling Water Inlet

122 Cooling Water Exit

\section{DRY COAL-FUELED SYSTEM \\ LOC Description}

17 Compressor Air Inlet

19 Compressor LP Cooling Exit

20 Compressor HP Cooling Exit

24 Compressor Air Exit

34 Combustor Gas Exit

35 Expander HP Cooling Inlet

36 Expander LP Cooling Inlet

40 Expander Exhaust

47 Combustor Fuel Inlet

120 Cooling Water Inlet

122 Cooling Water Exit

\begin{tabular}{|c|c|c|}
\hline $\begin{array}{l}\text { Press } \\
\text { psia }\end{array}$ & $\begin{array}{c}\text { Temp } \\
{ }^{\circ} \mathrm{F}\end{array}$ & $\begin{array}{l}\text { Flow } \\
1 \mathrm{~b} / \mathrm{h}\end{array}$ \\
\hline $\begin{array}{l}14.7 \\
105.3 \\
203.7 \\
199.3 \\
185.4 \\
202.8 \\
103.2 \\
15.13 \\
280.7 \\
660.3 \\
403.9\end{array}$ & $\begin{array}{r}59.0 \\
507.1 \\
714.1 \\
714.1 \\
1850.0 \\
640.5 \\
507.1 \\
715.1 \\
59.0 \\
417.8 \\
468.0\end{array}$ & $\begin{array}{r}5,395,896 \\
118,845 \\
393,861 \\
4,883,190 \\
5,130,836 \\
393,861 \\
118,845 \\
5,643,542 \\
253,815 \\
2,857,492 \\
2,857,492\end{array}$ \\
\hline
\end{tabular}

Press
psia

14.7

105.3

203.7

199.3

185.4

202.8

103.2

15.13

280.7

660.3

403.9

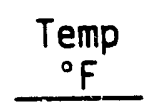

59.0

507.1

714.1

714.1

1850.0

640.5

507.1

713.8

59.0

417.8

468.0

\begin{tabular}{r}
$F 10 w$ \\
$1 \mathrm{~b} / \mathrm{h}$ \\
\hline $5,395,896$ \\
117,232 \\
388,515 \\
$4,890,149$ \\
$5,048,972$ \\
388,515 \\
117,232 \\
$5,554,719$ \\
139,702 \\
$2,621,524$ \\
$2,621,524$
\end{tabular}

The turbomachinery for the Reference System is assumed to be designed for the operating conditions of the Reference System; this is not an existing turbine operating at Reference System conditions. The compressor and turbine efficiencies are the efficiencies of the W501B operating on natural gas. Operating with the flows and temperatures of the Reference System, however, an actual W501B would probably not match the performance of the Reference System turbine, because it would be operating at off-design conditions. The performance of the 501B-type turbine used for the Reference System, but fueled by natural gas, is shown in Table 6-5. 
Table 6-5. Turbine Performance With Natural Gas

$\begin{array}{lrr}\text { Compressor Pressure Ratio } & 14: 1 & 14: 1 \\ \text { Inlet Air Flow, 1b/s } & 749 & 749 \\ \text { Combustor Exit Temperature, }{ }^{\circ} \mathrm{F} & 1850 & 2000 \\ \text { Exhaust Temperature, ' } \mathrm{F} & 703 & 769 \\ \text { Exhaust Flow, 1b/s } & 767 & 769 \\ \text { Generator output, kW } & 86,571 & 96,726 \\ & & \\ \text { Natural Gas Energy, MBtu/h (HHV) } & 948 & 1,052 \\ \text { Natural Gas Energy, MBtu/h (LHV) } & 854 & 948 \\ \text { Heat Rate, Btu/kWh (HHV) } & & \\ \text { Heat Rate, Btu/kWh (LHV) } & 9,944 & 10,879 \\ \end{array}$

\subsubsection{Compressor}

The 19-stage axial compressor has variable-angle inlet guide vanes and tuned stainless steel blades. The stainless steel vanes are inner shrouded to provide a rugged diaphragm assembly, and coated with low temperature, aluminum-rich coating to prevent corrosion. Each stage is provided with stepped labyrinth seals. Vane assemblies can be removed without removing the rotor.

The compressor used is aerodynamically similar to the compressor of the Westinghouse W501B gas turbine. The compressor is assumed to have an infinitesimal stage (polytropic) efficiency of 0.9057 , resulting in an isentropic efficiency of 0.86 when operated at the design pressure ratio.

\subsubsection{Slagging Combustor}

The slagging combustor, shown in Figure 6-1, is a modular unit with three principal stages. The first stage is the primary combustion zone or compartment. Coal and pre-heated compressed air, enter the primary zone coaxially through several, equally spaced injection nozzles. This coaxial injection promotes intense air and coal mixing and rapid particle heat-up and devolatilization, which minimize carbon burn-out time.

The incoming coal-air jets converge at the combustor center line and form one vertical jet which impacts the combustor dome. This forms a toroidal vortex which provides the mechanisms for flame stabilization and centrifugal separation of larger ash and slag particles. The separated ash and slag form a stable flowing layer on the combustor walls. The vertical geometry of this stage allows gravity to assist in the removal of the molten slag. Fuel-rich conditions in the primary combustion zone inhibit $\mathrm{NO}_{x}$ formation from fuel-bound nitrogen. They also provide the necessary reducing conditions for removal and capture of sulfur. The sulfur sorbent, limestone, dolomite, hematite or magnetite is counter-flow injected into the downstream end of the primary zone. The first stage is designed for a coal particle residence time of about $100 \mathrm{~ms}$ (for 75 micron sized particles). 
For slagging to occur, temperatures throughout the combustion chamber, and particularly at the walls, must not fall below about $2,600^{\circ} \mathrm{F}$ depending upon the type of coal. These temperatures are achieved by employing a proper air to fuel ratio, by providing adequate design for refactory walls, and sufficient residence time for the reacting coal to air mixture.

The second stage of the direct coal-fired combustor is an efficient impact separator which is closely coupled to the first silge. The impact separator removes particulates carried over with the gas from the primary zone, whether they are sorbent or fine particles of ash.

A slagging cyclone separator has been incorporated into the current subscale combustor configuration. This slagging cyclone provides a further reduction in particulate emissions. The manner in which these particulates are removed represents a novel application of a cyclone separator. At the high temperatures in the combustor second stage, the ash particles to be separated are molten and sticky. Operation with liquid ash alleviates potential problems due to re-entrainment of separated slag and allows the use of higher than normal tangential inlet velocities, thereby generating high inertial separation forces and improved collection performance.

In the third stage of the slagging combustor, complete combustion is accomplished and the combustion gases are tempered to meet turbine inlet requirements. This stage preferably consists of a single module with a pressure shell as is found in the first two stages. Combustion and dilution air are introduced through two rows of injection tubes with approximately sixteen tubes per row circumferentially spaced.

\subsubsection{Expander}

The four-stage expander has variable reaction with a high temperature drop in the first stage vane. The blades are made of forged superalloy with extended necks. The first two stages are air-cooled and coated with precious metal aluminide. All blades are individually replaceable with the rotor in place.

The vanes are made of cast superalloy, with the first two stages air-cooled. The first stage vanes are replaceable vithout lifting the cover. The cylinder uses blade ring construction with rollout feature to permit the replacement of vane segments with the rotor in place. Minimum leakage, interstage labyrinth seals are concentrically located by radial keys for independent transient expansion.

The expander is similar to the expander of the Westinghouse W501B gas turbine. The expander is assumed to have an infinitesimal stage (polytropic) efficiency of 0.9159 , resulting in an isentropic efficiency of 0.936 when operated at the design pressure ratio.

\subsubsection{Generator-Exciter Assembly}

The generator-exciter assembly is a direct-connected, hydrogen-cooled, $3600-\mathrm{rpm}$, non-salient pole unit rate at 0.9 power factor. Coils are insulated with Thermalastic for long life. A permanent magnet generator powers the voltage regulator, which controls the stationary field of a brushless exciter. 
The two-pole, 3-phase, 60-Hertz synchronous generator is rated at 13,800 volts. The generator uses:

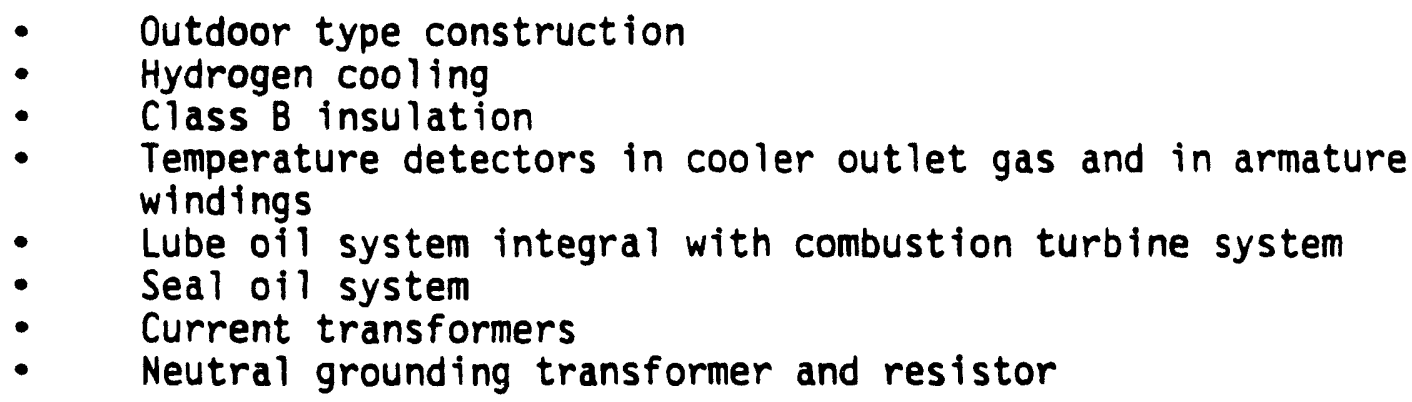

The exciter assembly is directly connected to generator. The brushless exciter consists of:

- Permanent magnet generator
- Alternating current exciter
- Rotating rectifier
- Space heaters
- Enclosure with lighting

\subsubsection{Auxiliaries}

The auxiliaries to the combustion turbine assembly consist of:

- $\quad$ Pipe rack assemblies

- Starting package

- Mechanical package

- Electrical/control package

- Coolers

- Inlet air system

- Exhaust Gas System

- Auxiliary transformers

- Isolated Phase Bus

- Fire protection system.

\subsection{Stean Turbine Cycle}

The components included in the steam turbine cycle are the heat recovery steam generator (HRSG), the reheat steam turbine, the generator, and the condenser. The steam bottoming cycle uses relatively low dual-pressure steam with reheat. There are no feedwater heating extractions above the deaerator. A single-chamber, double-pass condenser is connected to the low-pressure turbine. Part-load operation is conducted with sliding pressure under singlevalve control.

The unfired dual-pressure boiler includes superheater, reheater, and HP and IP evaporators that provide motive steam, and an LP evaporator that provides steam for the deaerator. The heat exchanger surfaces are extended on the gas side, and the construction is modular to minimize field assembly. 
The boilers use foiced circulation. Feedwater treatment consists of chemical treatment, deaeration, and blowdown from the steam drums. The gas leaving the HRSG is $50^{\circ} \mathrm{F}$ hotter than the acid dewpoint of the products of combustion, so corrosion of the HRSG is not expected to be a problem.

The steam turbine uses full annulus admission for uniform thermal expansion, fast starting, and fast load change. The steam turbine is directly connected to a hydrogen-cooled, 3600-rpm, $60-\mathrm{Hz}$ electric generator. Speed governing is provided to allow the steam turbine to be accelerated to and synchronized with the $60-\mathrm{Hz}$ system. The performance characteristics of the reheat steam turbine cycles for both the CWM-fueled and the dry coal-fueled systems are tabulated in Table 6-6.

Table 6-6. Steam Turbine Performance Data

Reference System Fuel

Combustor Cooling Water

Cooling water flow

Temperature entering Combustor

Temperature leaving Combustor

Energy transferred to HRSG

HP Turbine

Throttle Pressure

Throttle Temperature

HP Steam Turbine Power

IP Turbine

Reheat Pressure

Reheat. Temperature

IP Steam Turbine Power

LP Turbine:

Inlet Pressure

Inlet Temperature

LP Steam Turbine Power

Condenser

Inlet Pressure

Inlet Temperature

\section{Losses}

Auxiliary Power

Losses

Steam Tur'oine Net Power
$60 / 40 \mathrm{CWM}$

Dry Coa

$\begin{array}{rl}2,621,524 & 1 \mathrm{~b} / \mathrm{h} \\ 417.8 & { }^{\circ} \mathrm{F} \\ 468.0 & { }^{\circ} \mathrm{F} \\ 146.4 & \mathrm{MMBtu} / \mathrm{h}\end{array}$

15,721

92

680

16,705

30

680

33,710

1.5

92.9

$(1,826)$

$\frac{1}{63,917}$

$\begin{array}{rl}367 & \text { psia } \\ 680 & { }^{\circ} \mathrm{F} \\ 15,310 & \mathrm{~kW}\end{array}$

$\begin{array}{rl}92 & \text { psia } \\ 680 & { }^{\circ} \mathrm{F} \\ 16,386 & \mathrm{~kW}\end{array}$

$\begin{array}{rl}30 & \text { psia } \\ 680 & \circ \mathrm{F} \\ 33,060 & \mathrm{~kW}\end{array}$

$\begin{array}{rl}1.5 & i r_{i}=\mathrm{Hg} \\ 92.9 & { }^{\circ} \mathrm{F}\end{array}$

\begin{tabular}{rr}
$(400)$ & $\mathrm{kW}$ \\
$\frac{(1,802)}{\mathrm{kW}}$ \\
\hline 62,555 & $\mathrm{~kW}$
\end{tabular}




\subsection{Slag Disposal System}

Molten slag is drained from each of the two combustors into two corresponding quench areas, where the slag is cooled and fractured by a water spray as illustrated in Figure 6-1.

The molten slag is water-quenched by several nozzles in the quenching zone. This cools the slag until it is substantially solid pieces. These pieces drop into a water bath. A moving chain conveyer in the bottom of the water bath moves the chunks of slag to a series of roller crushers in the slurrying/ processing region. The crushed slag is slurried in water, preferably with an impeller and allowed to return to atmospheric pressure by passing out of the apparatus through a pressure let-down valve. Slurry exiting the pressure letdown valve is fed into a recycling zone. The slurry is preferably pumped into a settling tank. The settling tank separates out the water from the slag particles to enable the removal of slag tailings and the recirculation of water back to the system. The slag tailings can be removed in a road or rail vehicle, or equivalent conveyer or transportation means. The recycled water can be pumped either back into the slurrying step or back into nozzles for quenching molten slag. 


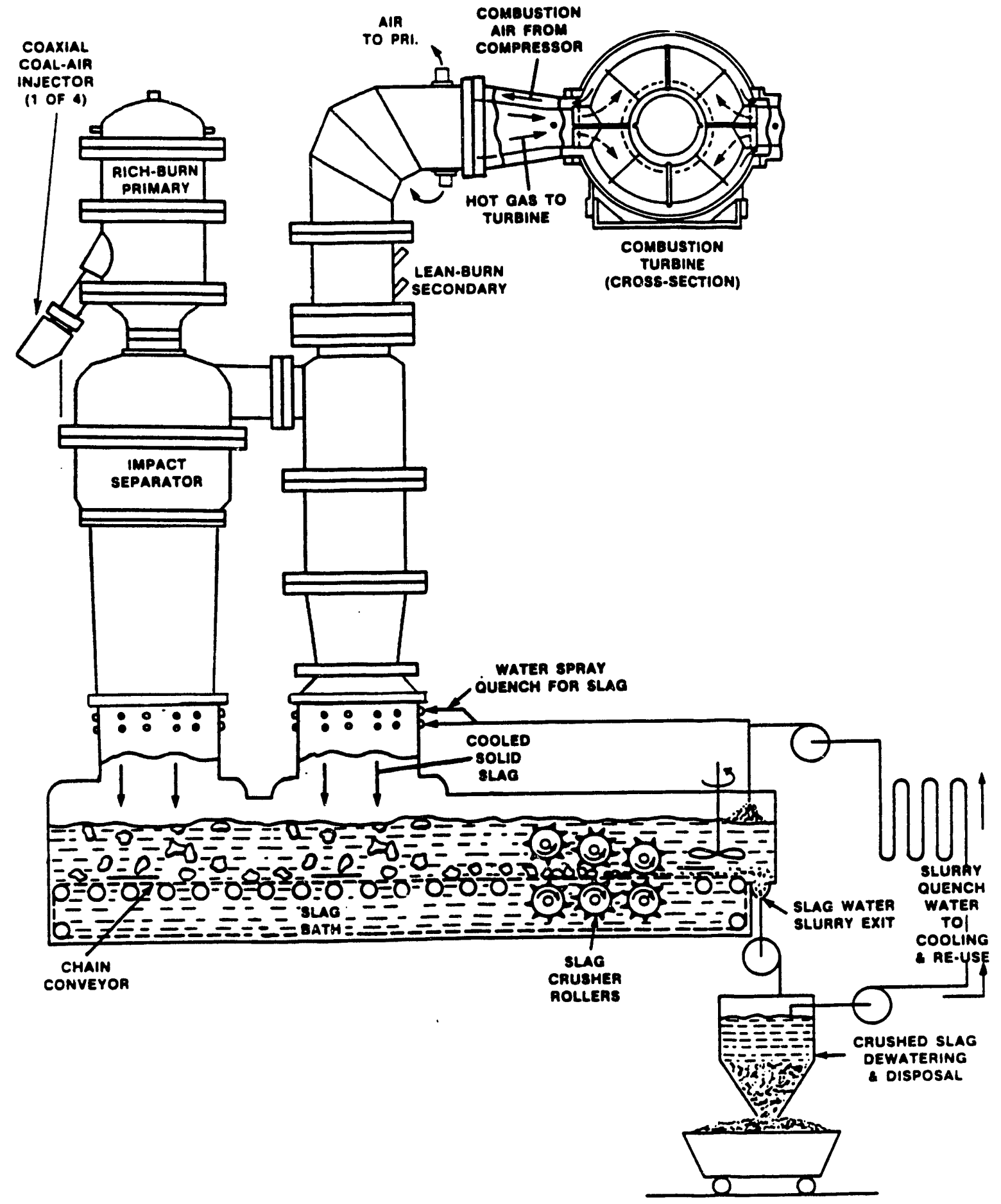

Figure 6-1. Direct Coal-Fired Combustion Turbine System 


\section{APPENDIX A - LICADO COAL CLEANING PROCESS}

The LICADO (Liquid CArbon DiOxide) process is a novel, advanced coal cleaning method conceived and patented by the University of Pittsburgh. Liquid carbon dioxide at high pressure (about $850 \mathrm{psig}$ ) and room temperature is used to separate clean coal from an aqueous suspension, leaving the ash and pyrite consituents in the water phase. Since liquid $\mathrm{CO}_{2}$ is immiscible in water, wets clean coal particles, and does not wet ash or pyrite particles, these properties result in the separation of clean coal from the water, ash, and pyrite at the liquid $\mathrm{CO}_{2}$-water interface. The effectiveness of this process has been demonstrated in bench-scale batch tests and in continuous tests up to $10 \mathrm{lb} / \mathrm{hr}$ at the University of Pittsburgh. These initial tests resulted in removal of up to $90 \%$ of the ash and pyritic sulfur.

\section{PLANT DESCRIPTION}

The following discussion of the plant refers to the components and their arrangement, as shown in Figure A-1.

\section{Feed Coal Preparation}

Feed coal preparation consists of a coal bin, crusher, weight indicator, wet grinder, slurry sump, coal/water slurry pumps, and the appropriate valves, cyclone classifier, feed storage, instrumentation, and controls. Here the coal is ground to 200 mesh for feed supply.

The coal/water slurry feed system employs pressurized recycle water. Maintaining the recycle water at high pressure reduces the substantial amount of absorbed $\mathrm{CO}_{2}$ lost, if the water were decompressed.

Some elements of the pressu, ized water feed system require multiple components based on plant requirements of coal feed slurry concentration with $10 \%$ weight solids, 1000 psig pressure, and vessel fabrication constraints of keeping the wall thickness between 1 to 2 inches.

A bucket lift delivers the fine coal to the coal feed receiver, which is at atmospheric pressure. Coal passes into one of two lock hoppers through a pipe and ball valve. The lock hoppers feed coal to the slurry tanks, which hold the slurry supply at about 840 psig. The total capacity of the lock hoppers is an 80-minute supply of feed coal, and the total capacity of the slurry tanks is a 60-minute supply of slurry. Mechanical mixers keep the coal/water slurry homogeneous in the on-stream tank, while the slurry pump drains the tank and supplies the hydraulic mixer. 


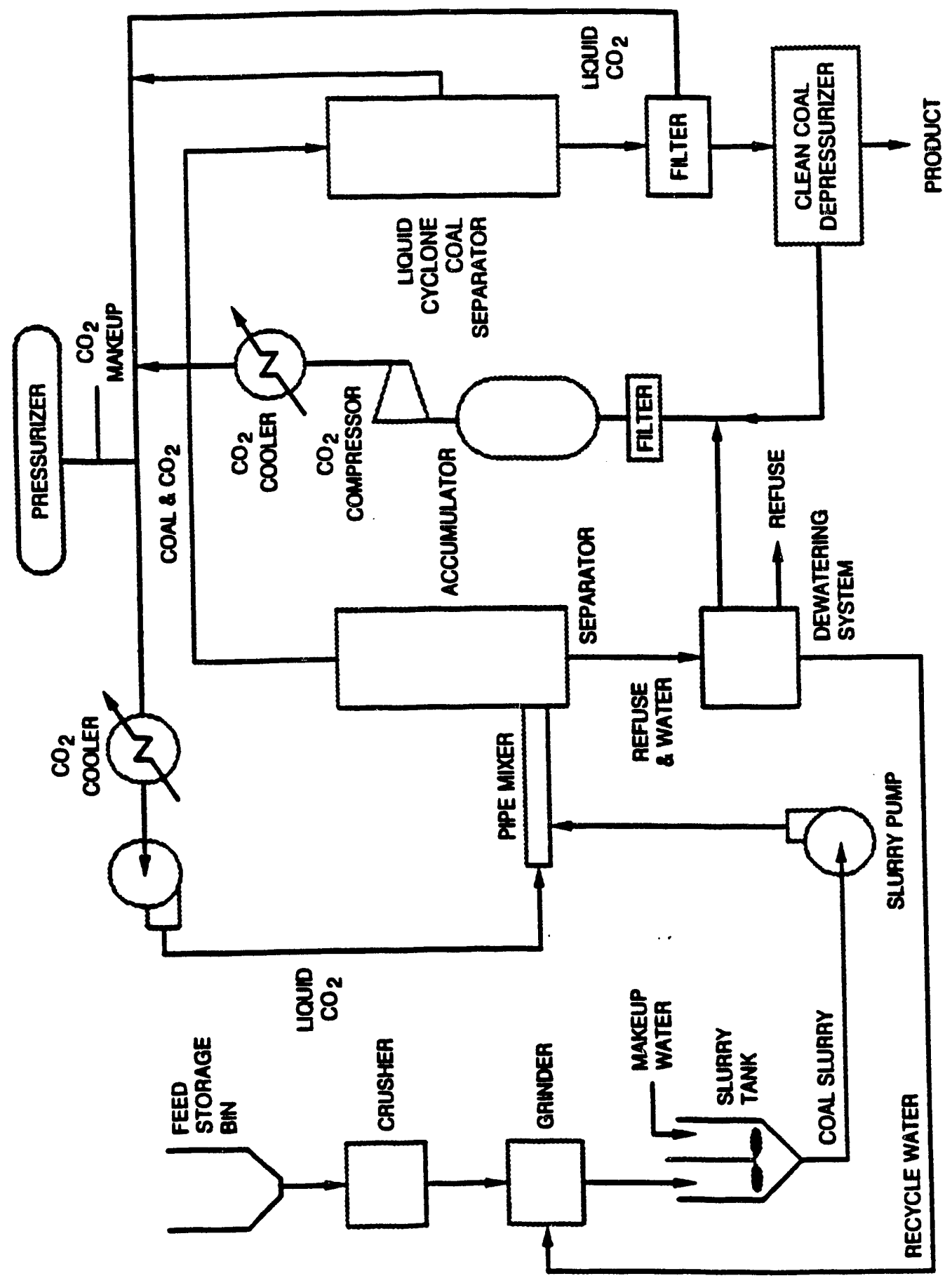

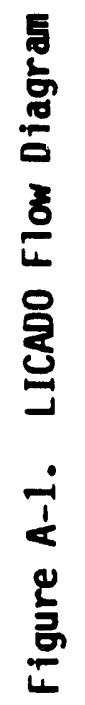




\section{Liquid CO2 Processing}

The liquid $\mathrm{CO}_{2}$ processing loop pump circulates subcooled liquid $\mathrm{CO}_{2}$ at approximate $1 y^{2} 860 \mathrm{psig}$ and $70^{\circ} \mathrm{F}$ through the hydraulic mixer, $\mathrm{CO}_{2} /$ water separator, $\mathrm{CO}_{2}$ clean coal filter, and $\mathrm{CO}_{2}$ loop cooler. Insulation covering the subsysten in conjunction with the $\mathrm{CO}_{2}^{2}$ cooler allows loop temperature control. A pressurizer maintains $\mathrm{CO}_{2}$ saturation pressure at about 840 psig through a temperature control system.

In the hydraulic mixer, liquid $\mathrm{CO}_{2}$ first contacts the coal/water slurry. Coal/water slurry enters along the axis of the mixer pipe while the liquid $\mathrm{CO}_{2}$ is injected into the water slurry through a multiholed nozzle. The 73 oneeighth inch diameter streams degrade to droplets due to the drag created on the $\mathrm{CO}_{2}$ stream by the difference in velocities of the coal/water and liquid $\mathrm{CO}_{2}$. This mixture of coal/water $/ \mathrm{CO}_{2}$ droplets flows through a series of orifice disks which further promote turbulence and thoroughly mix the stream. Orifice plates are of two patterns and alternate along the length of the mixer.

The unit has four separation stages within one pressurized column. The separator column has a pressure she 11 of Schedule 40 , 304 stainless steel pipe. The column bottom is a steep conical section with a center discharge to facilitate fluid flow with a high solids concentration.

The $\mathrm{coa} / / \mathrm{CO}_{2}$ exits the column through two diametrically opposed pipes below the unit top. Water containing refuse and pyritic sulfur issues from the bottom. The raw $\mathrm{COal} /$ water $/ \mathrm{CO}_{2}$ feed nozzle is approximately one-third the distance up the column. The top of the column is closed by a $600-1 \mathrm{~b}$ blind flange from which all of the column internals are supported or pass through. All of the internals are removed from the column when the top flange is raised.

Each separator stage consists of a conical flow tube through which the mixture of $\mathrm{coal} /$ water $/ \mathrm{CO}_{2}$ is accelerated by a propeller at the lower and larger diameter end. ATso, attached to the lower or base end of the conical flow tube is a tubular ring with eight small holes directed toward the center of the cone and propeller. Either $\mathrm{CO}_{2}$ or water may be injected through these holes to enhance coal/refuse separation. The mixer velocity, as it passes through the conical flow tube, will be increased and be discharged at $45^{\circ}$ toward the column periphery. The heavier refuse/ water will travel further and concentrate near the column wall, while the lighter $\mathrm{Coal} / \mathrm{CO}_{2}$ will remain nearer the center of the column. Stages are separated by a quiescent zone.

All mixing blades are positioned along a single central shaft driven from above through a magnetic coupling to the externally mounted motor. 


\section{Clean Coal Recovery}

Cleaned coal and $\mathrm{CO}_{2}$ exit the top of the separators (approximately 12 percent solids by weight). The $\mathrm{coa} / / \mathrm{CO}_{2}$ slurry flows through a cyclone into the auger filters operating at saturated conditions. The feed slurry liquid level is maintained in the filter medium auger leg with saturated vapor above the liquid in the remaining auger 1 eg and in the vertical coal receiver leg. The auger constantly turns at 1 to 3 RPM, stipping coal from inside the filter medium and delivering it to the top of the unit where it falls into the coal receiver leg. The coal in each filter is cyclically discharged into the product collection vessel (depressurizer tank), in which it is depressurized. The $\mathrm{CO}_{2}$ goes to a $\mathrm{CO}_{2}$ accumulator while the clean coal is pneumatically transported to large storage silos. Filtrate (liquid $\mathrm{CO}_{2}$ ) from the filters is delivered to the $\mathrm{CO}_{2}$ loop pressurizer.

\section{Refuse Disposal}

Refuse and water are constantly drawn from the bottom of the separator, at about 3-4\% wt. solids concentration, through a level control valve and into a cyclone separator within the refuse letdown tank. Water with absorbed $\mathrm{CO}_{2}$ vents from the top of the cyclone, while concentrated refuse is drained from the bottom. Expanded $\mathrm{CO}_{2}$ vents to the recycle subsystem while the water is decanted from over the refuse and passes to the pressurized recycle water tank. While the first tank is filling, refuse settling, and water being decanted, the second tank is discharging refuse sludge from the bottom for disposal. Both the product and refuse tanks are duplicated to assure continuous plant operation by switching from Tank 1 after filling to Tank 2 .

\section{Gaseous $\mathrm{CO}_{2}$ Recycle}

Some $\mathrm{CO}_{2}$ will accompany the refuse and product in the depressurizing operation. Economics and considerations require that this gaseous $\mathrm{CO}_{2}$ be compressed and recycled to the liqui: $\mathrm{CO}_{2}$ loop. The gaseous $\mathrm{CO}_{2}$ subsystem contains filters, accumulator, compressor, and after-cooler.

\section{Plant Operation}

Run of mine coal is loaded into the hopper outside the building and is fed onto a weight feeder inside the building. The feeder conveys the raw coal to a crusher where it is reduced to $1 / 4$ inch and smaller. A ball mill wet grinds the $1 / 4$ inch coal to a 200 mesh top size and discharges it into a sump from which a slurry pump delivers the coal fines to a wet cyclone classifier. The overflow from the cyclone carries the 200 mesh and smaller particles to feed storage, while the cyclone underflow returns oversized material to the ball mill. 
From the feed storage, where the excess water drains back to the atmospheric recycle water tank, a bucket conveyer 1 ifts the 200 mesh top size coal to the top of the building and deposits them into the feed receiver. The feed receiver supplies the lock hoppers, which have a combined capacity equal to an 80-minute supply. Ball valves isolate the feed receiver from the lock hoppers to allow pressurization of the lock hoppers with $\mathrm{CO}_{2}$ saturated vapor. From this point, the slurry tank, refuse letdown tank, coal depressurizer, and recycle water tank are interconnected with a pressure equalization system, which is connected to the vapor space in the pressurizer and maintains these vessels at $\mathrm{CO}_{2}$ saturation pressure of $840 \mathrm{psig}$ at $70^{\circ} \mathrm{F}$. However, each tank may be isolated from the equalization system, if desired.

The slurry tanks have a combined capacity equal to a 60-minute process feed supply. The number of tanks is a multiple of 3 . While Tank 1 is on-stream, Tank 2 is mixing and Tank 3 is baing filled. To fill a tank, water is first filled to a prescribed level, the stirrer turned on, and then the contents of a lock hopper is deposited into the slurry tank. The concentration may be changed by controlling the amount of coal added.

A slurry pump increases the feed pressure to approximately 900 psig to supply the hydraulic mixer. Liquid $\mathrm{CO}_{2}$ is injected into the slurry within the mixer. The mixer has a series of eight orifice plates through which the coal/water $/ \mathrm{CO}_{2}$ mixture passes. Pressure drop through the mixer is calculated to be approximately 50 psig.

The mixture enters the separator which has four stages, each of which separate and concentrate the $\mathrm{Coal} / \mathrm{CO}_{2}$ and water/refuse phases of the previous stage.

The $\mathrm{coa} 1 / \mathrm{CO}_{2}$ phase concentrates near the center of the column and exits the unit at the top, while the heavier water/refuse phase accumulates at the column periphery and exits at the bottom of the column.

The slurry pump flow rate, plus the $\mathrm{CO}_{2}$ flow rate equal the total separator inlet flow, while the outlet flow is balanced by control of the water/refuse stream exit rate through the bottom $\mathrm{CO}_{2}$ /water interface level indication. Thus, the remaining $\mathrm{Coal} / \mathrm{CO}_{2}$ outlet flow is automatically established.

Water, refuse, and absorbed $\mathrm{CO}_{2}$ are drawn from the bottom of the separation vessel and into the liquid cyclone within one of the two refuse letdown tanks. Concentrated solids exit from the bottom of the cyclone, while water and absorbed $\mathrm{CO}_{2}$ vent from the top. Solids will concentrate in the tank bottom while water is decanted from over the refuse and returned to the pressurized recycle water tank. When a prescribed solids level is reached in the on-line tank, it will be isolated from the system; and flow will be diverted to the second tank. $\mathrm{CO}_{2}$ will be vented to the accumulator from the first tank to reduce its pressure to about $25 \mathrm{psig.} \mathrm{This} \mathrm{pressure} \mathrm{will} \mathrm{be}$ used to force the refuse sludge out of the vessel into disposal drums. 
At some time during operation of the plant, runs will be made to investigate continuous venting of refuse sludge and recycle water from one tank only; thus, the second tank will be held in reserve.

The same product will be used for the coal depressurizing tanks.

The product stream (approximately 12 percent solids, coal/ $\mathrm{CO}_{2}$ ) from the top of the separator is concentrated in a cyclone to about 25-percent solids before it enters one of two auger filters. The second filter is a standby unit. Any coal fines in the overfiow are recirculated to the separator with the $\mathrm{CO}_{2}$ flow.

Coal cake is delivered by the auger to the receiver leg and flows through into the depressurizer tank. At a prescribed level in the depressurizer tank, it is isolated from the system; $\mathrm{CO}_{2}$ is vented to the accumulator until the tank pressure is $10 \mathrm{psig}$. Then this pressure is used to discharge the product. Meanwhile, the coal filter cake continues to fill the receiver leg of the filter until the emptied receiving tank is put back into the system, at which time the cycle is repeated. 


\section{APPENDIX B - OTHER COAL CLEANING PROCESSES}

Three physical coal cleaning (PCC) and two chemical coal cleaning (CCC) processes were selected to represent alternatives to LICADO coal cleaning and no coal cleaning. The processes are:

\section{Physical Coal Cleaning}

PCC I: $\quad$ (Dense-Medium (DM) Vessels, DM Cyclones, Froth Flotation)

PCC II: (DM Cyclones at Low and High Gravity, Froth Flotation)

PCC III: (DM Cyclones, Concentrating Tables)

\section{Chemical Coal Cleaning}

TRW: $\quad$ Gravichem (Ferric Sulfate Oxidation of Sulfur)

Kennecott: (Oxygen Oxidation of Sulfur)

\section{PROCESS DESCRIPTIONS}

The process descriptions are taken from Evaluation of Physical/Chemical Coal Cleaning and Flue Gas Desulfurization, Interagency Energy/Environment R\&D Program Report, United States Environmental Protection Agency, EPA-600/7-79250 (November 1979).

The three PCC processes represent widely used commercial technology; they were selected for study because they offer a relatively high degree of sulfur reduction compared with other PCC methods. The two CCC processes are not commercial processes, but have been developed to bench-scale or limited pilotplant stages. Additional development could make significant changes in the ir technical, and thus economic, potential for sulfur reduction. The PCC processes are somewhat limited in their desulfurization application because they removed only pyritic sulfur. One of the CCC processes removes significant quantities of organic sulfur in addition to pyritic sulfur.

\section{PCC I: Dense-Medium (DM) Vesse1s, DM Cyciones, Froth Flotation}

In the PCC-I process, raw coal is crushed to three size fractions, each of which is processed separately. A DM vessel is used for the coarse coal, a DM cyclone for the intermediate-sized coal, and froth flotation for the fine coal. The process includes raw coal sizing, coarse coal cleaning, intermediate coal cleaning, and fine coal cleaning. An additional grinding step was added to the basic PCC-I process to pulverize the coal for the slagging combustor. 


\section{PCC II: DM Cyclones at Low and High Gravity, Froth Flotation}

In the PCC-II process, the coal is crushed, then the coarse fraction is processed in DM cyclones operated at low specific gravity to produce a small overflow of highly cleaned coal. The bottoms from the low-gravity cyclones are pumped to high-gravity cyclones to produce "middling" (medium-quality coal) and refuse. The fine coal is recovered by froth flotation. The process includes raw coal sizing, low-gravity cleaning, normal-gravity cleaning, and fine coal cleaning. An additional grinding step was added to the basic PCC-II process to pulverize the coal for the slagging combustor.

\section{PCC III: DM Cyclones, Concentrating Tables}

In the PCC-III process, about two-thirds of the crushed coal is a coarse fraction treated in DM cyclones. A fine coal fraction, amounting to about one-third of the coal feed, is cleaned on concentrating tables. The remaining very fine coal fraction is thickened and filtered without cleaning and is added to the clean coal product. The process includes raw coal sizing, coarse coal cleaning, and fine coal cleaning. An additional grinding step was added to the basic PCC-III process to pulverize the coal for the slagging combustor.

\section{TRW Gravichem: Ferric Sulfate Oxidation of Sulfur}

TRW Defense and Space Systems Group developed the Gravichem coal desulfurization process and claims the process will remove 90 to 99 percent of the pyritic sulfur, but none of the organic sulfur. The process has been demonstrated in an 8-ton-per-day plant at a TRW test site. The process consists of a sink-float gravity separation, followed by selective oxidation of the pyrite in the sink fraction with ferric sulfate, followed by acetone leaching to recover elemental sulfur.

The basic process includes grinding to 28 mesh and briquetting the final product. To make the final product consistent with the other slagging combustor fuels, additional grinding was added to reduce the coal to 100 mesh, and the briquetting step was removed. The added cost of grinding and the reduced cost of briquetting were assumed to cancel each other.

\section{Kennecott: Oxygen 0xidation of Sulfur}

Kennecott Copper Corporation began development of this process in 1970 and continued work through 1975 when the process was demonstrated at a bench-scale level. The process consists of an oxidation system in which 85 to 95 percent of the pyritic sulfur and up to 30 percent of the organic sulfur in the coal are oxidized to soluble sulfates by sparging oxygen through the pulverized coal at a high temperature and pressure.

The basic process includes grinding to 28 mesh and pelletizing the final product. To make the final product consistent with the other slagging combustor fuels, additional grinding was added to reduce the coal to 100 mesh, and the pelletizing step was removed. The added cost of grinding and the reduced cost of pelletizing were assumed to cancel each other. 


\section{COST AND POWER ALGORITHMS}

Each coal cleaning process was analyzed using four variations of coal with sulfur contents of $0.7 \%, 2.0 \%, 3.5 \%$, and $5.0 \%$. The 3.5-percent-sulfur cases were used as the bases for comparison because they were closest to the 3percent sulfur content of the Pittsburgh No. 8 coal used for the slagging combustor.

The estimated total direct cost (TDC) of each complete process is assumeo to be a function of the inlet coal feed rate and the degree of sulfur removal. The cost algorithm and tabulated constants below are based on the costs of plants that use 3.5-percent-sulfur as the feed coal.

$$
\begin{aligned}
& \left.T D C=C r e f(\text { Wc/Wref })^{0.7} \text { (Sr/Srref) }\right)^{e} \\
& +\operatorname{PSref}(W C / 38.35)^{0.65}+\operatorname{C1ref}(W c / 38.35)^{0.75} \\
& +\operatorname{MXref}(W c / 38.35)^{0.5}
\end{aligned}
$$

where:

$$
\begin{aligned}
& \text { TDC = Total Direct Cost, thousands of } 1989 \text { dollars } \\
& \text { Ciref }=\text { Coal Injection System reference cost, } k \$(1989) \\
& \text { [see Table B-1] } \\
& \text { Cref }=\text { TDC of reference plant, } k \$(1989) \text { [see Table B-1] } \\
& \text { e } \quad \text { Capacity ratio exponent, dimensionless [see Table B-1] } \\
& \text { PSref = Pulverizer System reference cost, } k \$(1989) \text { [see Table-1] } \\
& \text { MXref = Miscellaneous reference cost, } k \$(1989) \text { [see Table B-1] } \\
& \mathrm{Sr} \quad=\text { Pyritic sulfur removal, decimal } \\
& \text { Srref = Pyritic sulfur removal of reference plant, decimal } \\
& \text { [see Table B-1] } \\
& \text { Wc }=\text { Coal feed rate, } 1 \mathrm{~b} / \mathrm{s} \\
& \text { Wref = Coal feed rate of reference } p l a n t, 1 b / s \text { [see Table B-1] }
\end{aligned}
$$

Table B-1. Key Cost and Design Parameters

\begin{tabular}{lrrrrr} 
& PCC I & PCC II & PCC III & TRW & KENNECOTT \\
\hline Cref, k\$(1989) & & & & & \\
Clref, $\$ \$(1989)$ & 5,532 & 42,646 & 41,766 & 138,277 & 166,322 \\
MXref, k\$(1989) & 5,017 & 5,017 & 5,017 & $-0-$ & $-0-$ \\
PSref, k\$(1989) & 990 & 990 & 990 & $-0-$ & $-0-$ \\
Ref. coal feed, t/yr & $4,480,000$ & $4,499,000$ & $4,148,000$ & $4,127,000$ & $4,326,000$ \\
Wref, lb/s & 414.82 & 416.57 & 416.11 & 382.13 & 400.56 \\
Srref, decimal & 0.5069 & 0.5285 & 0.4728 & 0.9786 & 0.8811 \\
e & 0.1 & 0.1 & 0.0 & 0.0 & 4.4
\end{tabular}

The auxiliary power and consumables requirements for each complete process are assumed to be a function of the inlet coal feed rate. The power and consumables algorithms and tabulated constants below are based on the costs of plants that use 3.5-percent-sulfur as the feed coal. 
Power

$$
\begin{aligned}
& \text { Pwr }=W c \star 3600 / 1000\left(C p+10^{x}\right) \\
& \begin{aligned}
P w r & =\text { Auxiliary power requirements, } \mathrm{kW} \\
C p & =\text { Power Coefficient, kWh/kIb [see Table B-2] } \\
W c & =\text { Coal feed rate, Ib/s } \\
x & =\text { Grinding exponent }(P C C-I, I I, \text { and III on Iy) } \\
& =2.27-1.673(L y)+0.412\left(L^{2}\right)-0.033\left(L^{3}\right) \\
L y & =\text { Log of final grind size, microns, } \log _{10}(14859 / \text { mesh })
\end{aligned}
\end{aligned}
$$

\section{Process water}

$W p w=C p w * W c * 3600 / 1000$

$$
\begin{aligned}
& W p w=\text { Process water requirement, } 1 \mathrm{~b} / \mathrm{h} \\
& \mathrm{Cpw}=\text { Process water coefficient, } 1 \mathrm{~b} / \mathrm{k} \text { ] }[\text { see Table } \mathrm{B}-2 \text { ] }
\end{aligned}
$$

\section{Diesel Fuel}

$$
\begin{aligned}
& \text { Wdf = Cdf } \star W c \star 3600 / 1000 \\
& \begin{array}{l}
W d f=\text { Diesel fuel requirement, } 1 \mathrm{~b} / \mathrm{h} \\
\text { Cdf }=\text { Diesel fuel coefficient, } 1 \mathrm{~b} / \mathrm{k} 1 \mathrm{~b} \text { [see Table B-2] }
\end{array}
\end{aligned}
$$

\section{Natural Gas}

$$
W n g=C n g \star W c \star 3600 / 1000
$$

Wng = Natural gas requirement, $1 \mathrm{~b} / \mathrm{h}$

Cng = Natural gas coefficient, $1 \mathrm{~b} / \mathrm{k}$ 1b [see Table B-2]

\section{Chemicals}

$$
\begin{aligned}
& \text { Wch }=C c h \star W c \star 3600 / 1000 \\
& \begin{aligned}
W c h=\text { Chemical feed required, } 1 \mathrm{~b} / \mathrm{h} \\
C c h=\text { Chemical feed coefficient, } 1 \mathrm{~b} / \mathrm{klb} \text { [see Table B-2] }
\end{aligned}
\end{aligned}
$$

The "cost factor" in the table is the cost of all chemicals plus other operating costs -- analyses, operating labor, and process steam -- divided by the weight flow of chemicals. Annual maintenance expenses, representing 6 percent of the capital cost per year, were also based on the values in the report. The cost factors are higher for the physical coal cleaning processes than for the chemical coal cleaning processes because of maintenance costs (which are large compared to the costs of actual consumables), and because of consumable feed rates (which are lower than for the chemical processes). 
Table B-2. Process Consumables (normalized per $1000 \mathrm{lb}$ feed coal)

\begin{tabular}{lrrrrr} 
& PCC I & PCC II & PCC III & \multicolumn{1}{c}{ TRW } & KENNECOTT \\
\hline Cp, kWh/k1b & 1.60 & 2.92 & 1.43 & 22.06 & 76.312 \\
Cpw, 1b/k1b & 36.86 & 65.81 & 21.62 & 14665.1 & 8426.66 \\
Cdf, ib/k1b & 0.09010 & 0.09194 & 0.08462 & $-0-$ & $-0-$ \\
Cng, 1b/k1b & $-0-$ & $-0-$ & $-0-$ & $-0-$ & $-0-$ \\
Cch, 1b/k1b & 0.56919 & 0.60457 & 0.40498 & 47.97061 & 248.4061 \\
Cost Factor, \$/k1b & 521.32 & 492.11 & 708.79 & 88.60 & 38.63
\end{tabular}

$$
\begin{gathered}
\text { END DATE } \\
6.1-92
\end{gathered}
$$

